\title{
Systematics and biogeography of the Boana albopunctata species group (Anura, Hylidae), with the description of two new species from Amazonia
}

Antoine Fouquet, Pedro Marinho, Alexandre Réjaud, Thiago R. Carvalho, Marcel A. Caminer, Martin Jansen, Raíssa N. Rainha, Miguel T. Rodrigues, Fernanda P. Werneck, Albertina P. Lima, Tomas Hrbek, Ariovaldo A. Giaretta, Pablo J. Venegas, Germán Chávez, and Santiago Ron

\section{QUERY SHEET}

This page lists questions we have about your paper. The numbers displayed at left are hyperlinked to the location of the query in your paper.

The title and author names are listed on this sheet as they will be published, both on your paper and on the Table of Contents. Please review and ensure the information is correct and advise us if any changes need to be made. In addition, please review your paper as a whole for typographical and essential corrections.

Your PDF proof has been enabled so that you can comment on the proof directly using Adobe Acrobat. For further information on marking corrections using Acrobat, please visit http://journalauthors.tandf.co.uk/production/acrobat.asp; https://authorservices.taylorandfrancis.com/how-to-correct-proofs-with-adobe/

The CrossRef database (www.crossref.org/) has been used to validate the references.

\section{AUTHOR QUERIES}

Q1 Please provide complete details for (Naka et al., 2018, Naka et al. 2018, Hime et al. 2020, Molak \& Ho, 2015, Papadopoulou et al., 2010, Drummond \& Rambaut, 2007, Bioacoustics Research Program 2012, Ronquist, 1997, Landis et al., 2013, Ree \& Smith, 2008, Avila-Pires et al. 2010, and Avila \& Kawashita -Ribeiro 2011) in the reference list or delete the citation from the text.

Q2 There is no mention of (Ceballos et al. 2015, Fouquet et al. 2007a, Fouquet et al. 2012, Günther 1858, Günther 1859, Klaus \& Matzke 2020, Silva et al. 2020 and Sturaro et al. 2020) in the text. Please insert a citation in the text or delete the reference as appropriate.

Q3 Please provide the volume number and page range.

Q4 Please provide the volume number and page range.

Q5 The year of publication has been changed as per Crossref details both in the list and in the text for this reference. Please check.

Q6 The year of publication has been changed as per Crossref details both in the list and in the text for this reference. Please check. 
Q7 If your paper introduces new zoological taxa at family-group level or below, you are now required to register your paper with ZooBank and insert the generated ZooBank ID (LSID) here. Individual new taxa need not be registered before publication; this can be done subsequently should you wish. Please go to http://www.zoobank.org/register to complete this task. You will need your article DOI to register. After publication, you must amend your ZooBank record of your paper to reflect the date of publication. Please see http://www.zoobank.org/help for further information. 
Research Article

Systematics and biogeography of the Boana albopunctata species group (Anura, Hylidae), with the description of two new species from Amazonia

\author{
ANTOINE FOUQUET $^{1}$ (D), PEDRO MARINHO ${ }^{2}$ (D), ALEXANDRE RÉJAUD ${ }^{1}$, THIAGO R. CARVALHO $^{3}$ (D), \\ MARCEL A. CAMINER ${ }^{4,5}$ D, MARTIN JANSEN ${ }^{6}$, RAÍSSA N. RAINHA ${ }^{7}$, MIGUEL T. RODRIGUES ${ }^{8}$ (iD, \\ FERNANDA P. WERNECK ${ }^{7}$, ALBERTINA P. LIMA $^{7}$, TOMAS HRBEK $^{9}$, ARIOVALDO A. GIARETTA $^{2}$ (D, \\ PABLO J. VENEGAS ${ }^{10}$, GERMÁN CHÁVEZ ${ }^{10} \&$ SANTIAGO RON $^{4}$ iD \\ ${ }^{1}$ Laboratoire Evolution et Diversité Biologique, UMR 5174, CNRS, IRD, Université Paul Sabatier, Bâtiment 4 R1 31062 \\ cedex 9, 118 Route de Narbonne, Toulouse, 31077, France \\ ${ }^{2}$ Laboratório de Anuros Neotropicais, Instituto de Ciências Exatas e Naturais do Pontal, Universidade Federal de Uberlândia, \\ Ituiutaba, MG, Brazil \\ ${ }^{3}$ Laboratório de Herpetologia, Departamento de Biodiversidade e Centro de Aquicultura, I.B., Universidade Estadual Paulista, \\ Rio Claro, SP, Brazil \\ ${ }^{4}$ Museo de Zoología, Escuela de Biología, Pontificia Universidad Católica del Ecuador, Quito, Ecuador \\ ${ }^{5}$ Institute of Organismic and Molecular Evolution, Johannes Gutenberg University Mainz, Germany \\ ${ }^{6}$ Department of Terrestrial Zoology, Research Institute and Nature Museum Senckenberg, Frankfurt, Germany \\ ${ }^{7}$ Instituto Nacional de Pesquisas da Amazônia, Coordenação de Biodiversidade, Manaus, AM, Brazil \\ ${ }^{8}$ Departamento de Zoologia, Universidade de São Paulo, Instituto de Biociências, São Paulo, SP, Brazil \\ ${ }^{9}$ Departamento de Genética, Universidade Federal do Amazonas, Manaus, AM, Brazil \\ ${ }^{10}$ Instituto Peruano de Herpetología, Lima, Peru
}

The outstanding species richness of Amazonia has fascinated biologists for centuries. However, the records of actual numbers and distribution of species forming its ecosystems are so incomplete that the understanding of the historical causes and regional determinants of this diversity remain speculative. Anuran clades have repeatedly been documented to harbour many unnamed species in this region, notably the Boana albopunctata species group. Considering the documented distribution and the ecology of the species of that group, we hypothesized that it diversified via successive trans-riverine dispersals during the late Miocene and Pliocene, after the formation of the modern Amazon watershed. To test this hypothesis, we gathered an extensive dataset of 16S rDNA sequences sampled throughout Amazonia and a mitogenomic dataset representative of the diversity of the clade to (1) re-evaluate species boundaries and distributions, and (2) infer the spatio-temporal history of diversification within Amazonia. We delimited 14 Operational Taxonomic Units (OTUs) in an Amazonian clade, i.e., 75\% higher than currently recognized (14 OTUs for eight described species). Combining molecular data with morphological and acoustic data, two new species, Boana courtoisae sp. nov. from the eastern Guiana Shield and Boana eucharis sp. nov. from Southern Amazonia, are described herein. These species belong to a clade that diversified throughout Amazonia during the last $10 \mathrm{Ma}$, thus more recently than co-distributed small terrestrial anurans but concomitantly with other more vagile vertebrates. Our time-scaled phylogeny and biogeographic analyses suggest an initial east-west divergence and confirm reciprocal trans-riverine dispersals during the last $5 \mathrm{Ma}$. The geomorphological evolution of the region and species-specific dispersal ability largely explain these distinct spatio-temporal patterns across anurans.

Key words: Amphibia, biodiversity, Guiana Shield, mitogenomics, neotropics, phylogenetics

\begin{tabular}{llll}
\hline Correspondence to: & Antoine & Fouquet. & E-mail: \\
fouquet.antoine@gmail.com; & Pedro & Marinho & E-mail:
\end{tabular}
pmarinho50@gmail.com

\section{Introduction}

The Neotropics harbour the most diverse ecosystems on the planet (Jenkins et al., 2013). Within the Neotropics, 
Amazonia stands as a major biogeographic region covering more than 6.5 million $\mathrm{km}^{2}$, including the largest continuous tract of tropical forest $(40 \%$ of the world's tropical rainforests), encompassing the most important drainage (Amazon River basin) and probably hosting the highest continental biodiversity on earth (Myers et al., 2000). The outstanding species richness of this region has raised many questions concerning its origins and diversification mechanisms. While all agree on the astounding diversity of Amazonia, our understanding of the actual number and distribution of species forming its ecosystems is in fact so incomplete (Ficetola et al., 2014; Meyer et al., 2015; Vacher et al., 2020) that it has so far hampered investigations at the regional scale. Consequently, the understanding of the historical causes and regional determinants of this outstanding diversity remain speculative (Antonelli et al., 2018). Another consequence is that the collision between the Linnean shortfall and the biodiversity crisis is particularly evident in Amazonia (Guerra et al., 2020). With almost the entire eastern and southern parts (25\%) of its extent being already deforested for agriculture, an unknown proportion of endemic species, and thus of the testimony of Amazonian history, has already vanished (Lovejoy \& Nobre, 2019).

Anuran clades have repeatedly been documented to harbour many unnamed species in Amazonia (Vacher et al., 2020) and to display strikingly allopatric distribution patterns that could provide crucial insights into Amazonia's past (Fouquet, Cassini, Haddad, Pech, \& Rodrigues, 2014; Réjaud et al., 2020). This is notably the case of the Boana albopunctata species group (Caminer \& Ron, 2014; Funk et al., 2012). This group is only defined on the basis of molecular data (Faivovich et al., 2005), and currently comprises 16 valid nominal species distributed in the Caribbean and South America: Boana albopunctata (Spix, 1824), Boana alfaroi (Caminer \& Ron, 2014), Boana almendarizae (Caminer \& Ron 2014), Boana caiapo Pinheiro et al., 2018, Boana calcarata (Troschel, 1848), Boana dentei (Bokermann, 1967), Boana fasciata (Günther, 1858), Boana heilprini (Noble, 1923), Boana lanciformis (Cope, 1871), Boana leucocheila (Caramaschi \& de Niemeyer, 2003), Boana maculateralis (Caminer \& Ron, 2014), Boana multifasciata (Günther, 1859), Boana paranaiba (Carvalho, Giaretta \& Facure, 2010), Boana steinbachi (Boulenger, 1905), Boana tetete (Caminer \& Ron, 2014) and Boana raniceps (Cope, 1862). Within this clade, B. heilprini is the most distinct since it is confined to Hispaniola and is phylogenetically distant from a clade formed by all the other species of the group (Duellman, Marion, \& Hedges, 2016). We can also distinguish $B$. raniceps and the $B$. albopunctata clade (B. lanciformis, B. albopunctata, B. multifasciata, B. paranaiba, B. caiapo, B. leucocheila), which occur widely in the open habitats of the Cerrado and Amazonia (Camurugi et al., 2021), from the Amazonian clade. According to Caminer and Ron (2014), this Amazonian clade is itself subdivided in two main groups, hereafter called the B. calcarata (B. fasciata, $B$. calcarata, $B$. almendarizae, B. maculateralis) and the $B$. steinbachi (B. tetete, B. alfaroi, B. steinbachi) clades.

Within this Amazonian clade, Funk, Caminer, and Ron (2012) identified no less than seven putative unnamed species based on mitochondrial divergence and acoustic data. These species add up to the 10 taxa that were valid at that time. Caminer and Ron (2014) completed this picture by documenting two additional lineages, describing four of the previously discovered species, and removing $B$. steinbachi from its synonymy with $B$. fasciata. However, sampling of both studies was circumscribed to western Amazonia (mostly Ecuador) while the species complex occurs throughout Amazonia. Populations from the eastern Guiana Shield lowlands are already assumed to belong to a yet unnamed species (Caminer \& Ron, 2014), but the status of numerous other populations throughout Amazonia, generally identified as B. fasciata, remain virtually unknown. More recently, Vacher et al. (2020) suggested, based on $16 \mathrm{~S}$ mitochondrial DNA (mtDNA) sequences, that up to 22 species could exist in that group and that the distribution of most species could be circumscribed to small ranges within Amazonia.

These aforementioned studies improved our understanding of the actual diversity in the B. calcarata/steinbachi clade, but left virtually unexplored the temporal and spatial context of the diversification within Amazonia. The crown age of this Amazonian clade was estimated between 16-11 million years ago (Ma) by Funk et al. (2012) and between 14-9 Ma by Duellman et al. (2016). Therefore, the initial diversification of that clade throughout Amazonia may have taken place during the final stage of the Pebas system, a freshwater lake occupying most of Western Amazonia from the early Miocene (23 Ma) until 10-9 Ma (Hoorn et al., 2017). Meanwhile, most of the diversification within the B. calcarata/steinbachi clade took place during the late Neogene (last $10 \mathrm{Ma}$ ). From $9 \mathrm{Ma}$ onward, this system has drained eastward into the Atlantic Ocean, but enormous flooded ecosystems (Acre system) still occupied a large portion of what we currently consider as Western Amazonia until 7 Ma (Hoorn et al., 2010; Albert, et al., 2018a). Subsequent river captures were common (Ruokolainen, Moulatlet, Zuquim, Hoorn, \& Tuomisto, 2018), as were climatic fluctuations that may have modified vegetation possibly to the point of forest 
fragmentation, at least in some peripheral parts of Amazonia (Cheng et al., 2013; Kirschner \& Hoorn, 2019). The relative roles of hydrological evolution (Albert et al., 2018b; Ribas, Aleixo, Nogueira, Miyaki, \& Cracraft, 2012) and rainforest expansion and contraction due to climate oscillations (Haffer, 1969) have been the focus of intense debate (Leite \& Rogers, 2013). Since the species of the $B$. calcarata and B. steinbachi complexes are associated with riparian forests, and these species mostly breed in pools formed on the banks of the beds of small to medium-sized rivers, very large rivers may act as barriers to dispersal, thus reducing or completely impeding gene flow and inhibiting homogenization of differentiating populations (Naka et al., 2018). However, smaller and highly dynamic meandering rivers probably represent more permeable barriers. Therefore, we assume that successive dispersals across major Amazonian rivers (parapatric speciation) (Pirani et al., 2019), as well as hydrological changes (vicariant speciation) (Naka et., 2018), could have been major processes of diversification in these frogs.

We gathered a large mtDNA dataset for the $B$. albopunctata group sampled throughout Amazonia combined with morphological and acoustic data for a subset of this group (the B. steinbachi clade), to address two main goals: (1) reevaluate species boundaries (in or among members) of the $B$. albopunctata group and their respective distributions, and (2) investigate its diversification history within Amazonia using mitogenomic data for one terminal of each delimited species. Furthermore, two species in the $B$. steinbachi clade that were unnamed are described herein.

\section{Materials and methods}

\section{Species delimitation}

Our first objective was to delimit all major Operational Taxonomic Units (OTUs) based on mtDNA main lineages. Our sampling included 55 new Boana tissue samples, obtained through fieldwork throughout Amazonia and adjacent Dry Diagonal (DD; Chaco, Cerrado, Caatinga; Werneck, 2011) and loans from collaborators (from collections QCAZ, MPEG, INPA, CORBIDI, AAGUFU, and from personal loans JMP, SCF, FTA; Appendix 1). Samples unambiguously identified (near type locality and/or phenotypically corresponding to type material) as belonging to the currently recognized taxa were included except $B$. paranaiba and B. caiapo. We sequenced a $\sim 400 \mathrm{bp}$ portion of the end of the $16 \mathrm{~S}$ rDNA gene, a locus commonly used for Neotropical amphibian taxonomy and systematics (Vences, Thomas, Bonett, \& Vieites, 2005). We also retrieved homologous sequences from GenBank (389 accessions). In total, we gathered $44416 \mathrm{~S}$ sequences for this study (dataset details are provided in Appendix 1 and DNA extraction and sequencing protocols can be found in Appendix 2). These samples cover the whole distribution of the B. albopunctata species group (14 included taxa). DNA sequence alignment, was conducted on the MAFFT7 online server under the E-INS-i option with default parameters, an algorithm designed for sequences with multiple conserved domains and long gaps (Katoh et al., 2019).

We applied three DNA-based single-locus species delimitation approaches: (a) a distance-based method, the Automated Barcode Gap Discovery (ABGD; Puillandre, Lambert, Brouillet, \& Achaz, 2012); (b) a multi-rate coalescent based method, the multi-rate Poisson Tree Processes model approach (mPTP; Kapli et al., 2017); and (c) a single-threshold coalescent-based method, the Generalized Mixed Yule Coalescent approach (single threshold GMYC; Monaghan et al., 2009; Pons et al., 2006).

The ABGD delimitation was performed with a prior of intraspecific divergence $P$ between 0.001 and 0.1 , a proxy for minimum relative gap width, $X$, of 1 , and a number of steps $n$ equal to 30 . We kept the partition such that $P=0.016$, as it corresponds to the end of a plateau for group number and it matches thresholds of intraspecific divergence proposed in other vertebrate delimitation studies using $16 \mathrm{~S}$ barcodes (Puillandre et al., 2012). For mPTP delimitation, we first reconstructed a Maximum Likelihood (ML) tree with RAxML v.8.2.4 (Stamatakis, 2014) using the GTR $+\mathrm{G}+\mathrm{I}$ substitution model and estimated nodal support via 1000 parametric bootstraps. We used nine outgroups representing most other Boana species groups (Appendix 3). The mPTP delimitation was undertaken on the rooted ML tree, with 5 million Markov chain Monte Carlo (MCMC) iterations, sampling every 10,000 th iteration, and a $10 \%$ burn-in. For the GMYC delimitation, we reconstructed a time-calibrated phylogeny using BEAST 2.5 (Bouckaert et al., 2014). We used a birth-death population model to account for extinction processes and incomplete sampling. We included the same nine Boana outgroups used in RAxML reconstruction and five additional representatives of other Cophomantini genera (Nesorohyla, Myersiohyla, Hyloscirtus, Aplastodiscus, Bokermannohyla) in order to include relationships that can be time-calibrated. We used a single partition with a GTR + G + I substitution model, with an uncorrelated relaxed lognormal clock model of rate variation among branches (Drummond, Ho, Phillips, \& Rambaut, 2006). We used two calibration points, the ages of the most recent common ancestor (MRCA) of Aplastodiscus and 
Boana, as well as the MRCA of a clade formed by Hyloscirtus, Boana, Aplastodiscus, and Bokermannohyla, which were estimated by Feng et al. (2017) and consequently constrained here assuming normal prior distributions of $25.2 \mathrm{Ma}$ (standard deviation $[\mathrm{SD}]=2.8 \mathrm{Ma})$ and $32.3 \mathrm{Ma}(\mathrm{SD}=3 \mathrm{Ma})$ respectively. We considered these calibrations to represent the best prior because Feng et al. (2017) included a comprehensive dataset of nuclear loci for an extensive sampling of anurans and used many reliable fossils as calibration points. Moreover, Hime et al. (2020), analysing an even larger genomic dataset, found very similar time estimates for the TMRCA of Boana+Hyloscirtus. Instead, using fossil and/or biogeographic calibrations would have implied to expand the matrix to lineages distantly related to Boana and would likely lead to an overestimation of calibration dates with our mitogenomic dataset (Molak \& Ho, 2015; Papadopoulou et al., 2010). For the MCMC parameters, we used four independent chains of 100 million iterations, recording every 10,000 th iteration, and a $10 \%$ burn-in. We combined the $\log$ files of the independent runs using LogCombiner 2.5 (Drummond \& Rambaut, 2007) and checked the convergence of our parameters, confirmed by all Effective Sample Size (ESS) being above 200. Then, we extracted the maximum clade credibility tree using Tree annotator 2.5 (Drummond \& Rambaut, 2007) with a burn-in of $10 \%$. After removing outgroups, we performed a GMYC delimitation on the ultrametric tree using the GMYC function of the splits R package v.1.011 (Ezard, Fujisawa, \& Barraclough, 2009), with a threshold interval between 0 and $10 \mathrm{Ma}$ and by using the single threshold method. Operational Taxonomic Units (OTUs) were defined using a majority-rule consensus from the results of the three methods, i.e., a lineage is considered as being an OTU if supported by at least two of the three methods.

All but five occurrence records were georeferenced and used to create distribution maps with convex polygons under QGIS 2.14 (QGIS Geographic Information System). OTUs were assigned to taxa based on the field/museum identification and sometimes corrected in accordance with type localities and known distribution (Frost, 2019; IUCN, 2020).

\section{Morphological and acoustic variation in the Boana steinbachi clade}

The following morphometric measurements were taken on 38 males and 9 females: snout-vent length (SVL), head length (HL), head width (HW), eye diameter (ED), tympanum diameter (TD), tibia length (TL), foot length (FL), thigh length (THL) and calcaneal appendage length (CL). In addition to these, we also measured hand length (HAL), forearm length (FLL), and eye-nostril distance (EN) for the morphometric characterization of holotypes. All measurements followed the definitions and terminology of Watters, Cummings, Flanagan, and Siler (2016). We classified the calcaneal appendage into three-character states: (i) a calcar (skin appendage with length $>1 \mathrm{~mm}$, flattened or conical); a (ii) skin flap (skin appendage with length $<1 \mathrm{~mm}$, flattened; or a (iii) tubercle, a conical structure with reduced size and, as such, not forming an appendage coming out of the heel. The specimens were measured by P. Marinho (Alta Floresta, Mato Grosso State and Assis Brazil, Acre State) using a Mitutoyo digital calliper (to the nearest $0.05 \mathrm{~mm}$ ), by M.T. Rodrigues (Jirau and Pacaás Novos, Rondônia State) using a Mitutoyo digital calliper (to the nearest $0.01 \mathrm{~mm}$ ), by A. Fouquet (French Guiana and Suriname) using a DigiMax digital calliper (nearest $0.01 \mathrm{~mm}$ ) and by M. Caminer (Ecuador, Peru and Bolivia) using a Mannesmann digital calliper (nearest $0.01 \mathrm{~mm}$ ). Snout shape was assessed according to Heyer et al. (1990). Digital webbing formulae followed the notation system of Savage and Heyer (1997).

Acoustic analysis of 27 recorded calling males (Appendix 4) was conducted in Raven Pro 1.5, 64-bit version (Bios 2012); sound figures were produced using Seewave version 2.1.0 (Sueur, Aubin, \& Simonis, 2008) and tuneR version 1.3.2 (Ligges, Krey, Mersmann, \& Schnackenberg, 2014), in R version 3.5.0 ( $\mathrm{R}$ Core Team 2018). Raven Pro settings: window size $=512$ samples; window type $=$ Hann; $3 \mathrm{~dB}$ filter bandwidth $=124 \mathrm{~Hz}$; window overlap $=85 \%$; hop size $=77 \mathrm{~ms}$; discrete Fourier transform $(\mathrm{DFT})$ size $=$ 1024 samples; grid spacing $=43.1 \mathrm{~Hz}$; seewave settings: window type $=$ Hanning; fast Fourier transform (FFT) size $=256$ samples; FFT overlap $=90 \%$. The analysed files are deposited in the sound collection of the 'Museu de Biodiversidade do Cerrado' (AAG-UFU), 'Fonoteca Neotropical Jacques Vielardi' (FNJV), 'La Sonothèque du Muséum National d'Histoire Naturelle' (MNHN) and the Macaulay library (MC). Detailed information about the analysed sound files and accession numbers are provided in Appendix 4.

Call types were distinguished based on the number of notes per call and pulsing. We defined as type 1 calls the multinote calls formed by nonpulsed notes, which consist of the main call type emitted by males of all studied species. Type 2 calls are emitted less often than type 1 and consist of a one-note call formed by poorly defined pulses. We only included type 1 calls in the acoustic diagnoses and the interspecific comparisons. The acoustic traits were generally analysed manually (if not stated otherwise), as follows: temporal traits (call 
duration, note duration, interval between notes, number of notes, and call rise time; the latter using the 'Peak Time' function); frequency traits (dominant frequency, using the 'Peak Frequency' function; minimum and maximum frequency using the 'Frequency 5\%' and 'Frequency 95\%' functions, respectively). Call traits used in the description followed the definitions and terminology of Köhler et al. (2017), using a note-centred approach.

\section{Time-calibrated species phylogeny}

We selected a representative for each of the 25 OTUs identified by the species delimitation (see Results), for complete mitogenome sequencing to investigate interrelationships and divergence times. Mitogenomic sequences were obtained using low-coverage shotgun sequencing. We recovered high-quality mitochondrial genome assemblies for 18 OTU representatives (see Appendix 2 for details regarding mitogenome sequencing, assembling and annotation). For the remaining seven OTUs for which we could not obtain tissue samples (Appendix 3), we gathered all the available mitochondrial loci (12S, 16S, ND1, COI, and Cytb) from GenBank; four of these OTUs were represented by $16 \mathrm{~S}$ only. We also selected 14 species as outgroups (nine with complete mitogenomes), including representatives for other Boana species groups and most other Cophomantini genera (Appendix 3).

We extracted 12S, $16 \mathrm{~S}$ and all protein-coding sequence regions (CDS, thus removing D-Loop and tRNAs) from complete mitogenomes as well as GenBank accessions and aligned each locus independently using the MAFFT7 online server. For rRNA genes, we chose the E-INS-i strategy, recommended for sequences with multiple conserved domains and long gaps. For the protein-coding genes, we chose the GINS-i strategy, designed for sequences with global homology (Katoh et al., 2019). Realignments of CDS considering the reading frame were done and concatenated in Geneious v.9.1.8 (https://www.geneious.com). Our final matrix totalled 39 terminals and 13,620 aligned nucleotide sites. Among these terminals, 27 were complete and nine had fewer than 3,000 nucleotides $(20 \%)$ but all were putatively closely related to terminals with complete data.

We selected the best-fit partition scheme and model of evolution for each partition using PartitionFinder V2.1.1 (Lanfear et al., 2016), based on the Bayesian Information Criterion (BIC). We predefined four data blocks, one for rRNA genes (12S and 16S) and one for each codon position of all CDS regions and found the $\mathrm{GTR}+\mathrm{I}+\mathrm{G}$ model to best-fit all partitions. We reconstructed a time-calibrated tree using a birth-death tree prior using BEAST 2.5, to account for extinction processes and incomplete sampling. We parameterized unlinked substitution models according to the estimates obtained in the PartitionFinder V2.1.1 analysis (Lanfear et al., 2016). We used the same two calibration points as in the previous BEAST analysis. Analyses were undertaken using uncorrelated relaxed lognormal clock model of distribution of rate variation among branches for each partition (Drummond et al., 2006). The Markov chain Monte Carlo (MCMC) parameters were set with four independent chains of 100 million iterations, storing every $10,000^{\text {th }}$ iteration and a $10 \%$ burn-in. We combined the $\log$ files of the independent runs using LogCombiner 2.5 and confirmed the convergence of our parameters as all ESS were above 200. Finally, we extracted the maximum clade credibility tree using Tree annotator 2.5. We acknowledge that our phylogenetic reconstruction solely based on mtDNA sequences prioritizes spatial and taxonomic completeness over genomic coverage and can lead to overestimated divergence times (e.g., McCormack, Heled, Delaney, Peterson, \& Knowles, 2011; Near et al., 2012).

\section{Biogeographic analysis}

Biogeographic inferences were undertaken on the timecalibrated phylogeny using the BioGeoBEARS R package (Matzke, 2013). This package reconstructs ancestral geographic distributions and investigates the role of each biogeographic event with a maximum likelihood algorithm. We compared three different models: (i) a likelihood version of the Dispersal-Vicariance (DIVALIKE) model (Ronquist, 1997); (ii) a likelihood version of the BayArea (BBM) model (Landis et al., 2013); and (iii) the Dispersal Extinction Cladogenesis (DEC) model (Ree \& Smith, 2008). We also compared versions of these models allowing jump dispersal as described by the J parameter (Matzke, 2013). Models were compared with the Akaike Information Criterion (AIC). We ran 50 independent BioGeoBEARS biogeographic stochastic mapping, to determine biogeographic event counts for the best-fit model (Dupin et al., 2017). Ree and Sanmartín (2018) voiced several criticisms against the use of $\mathrm{J}$ parameter arguing that it inflates the contribution of cladogenetic events to the likelihood, and minimizes the contribution of anagenetic, timedependent range evolution. We thus also compared the results from the best model without jump dispersal.

Since this work focuses on the historical biogeography of the Amazonian clade, we discarded the two early diverging lineages $B$. heilprini and $B$. raniceps from the biogeographic analyses since their distribution 
ranges lie mostly outside of Amazonia. We considered three areas within Amazonia: Western Amazonia, the Brazilian Shield, and the Guiana Shield. These areas correspond to major geological features roughly delimited by modern riverine barriers: the Madeira River, the Negro River, and the lower course of the Amazon River and to three large biogeographic regions known as Wallace's districts (Hoorn et al., 2010; Wallace, 1854). These districts were recently confirmed as major breaks in birds' species composition (Oliveira, Vasconcelos, \& Santos, 2017) and amphibians (Godinho \& da Silva, 2018; Vacher et al., 2020), strengthening their status of biogeographic regions. Because the distribution range of the $B$. albopunctata group extends outside Amazonia, we included in the ancestral range reconstruction one additional non-Amazonian Neotropical area, the Dry Diagonal.

\section{Results}

\section{Species delimitation}

Of the three tested methods of species delimitation, the ABGD method was found to be the most conservative, delimiting 21 OTUs while mPTP and GMYC delimited 24 and 47 OTUs, respectively (Appendix 1). In one case, the consensual partitioning was overly conservative given that $B$. leucocheila and B. multifasciata were considered as a single OTU which is contradicted by the fact that these two taxa are phenotypically distinct. Therefore, we kept the different lineages delimited by GMYC in this group as distinct OTUs. The final delimitation led to 25 OTUs (including $B$. heilprini) in the $B$. albopunctata species group (Fig. 1, Appendix 1). Thirteen of these OTUs could be linked to nominal species (except $B$. caiapo and B. paranaiba that were not included in the analysis because material was not available). Conversely, 11 could not be linked to any nominal species, representing a possible $44 \%$ increase in the species richness of the group. The Amazonian clade itself was represented by 14 OTUs including eight nominal species and six putative new species (Fig. 1). These results also imply important changes to the geographic distribution of the species of the group. In Appendix 5, we detail and justify the identification of these OTUs and their respective geographic ranges.

\section{Taxonomic accounts}

The Amazonian clade of the $B$. albopunctata group, previously reported as the $B$. calcarata- $B$. fasciata species complex by Caminer and Ron (2014), is composed of two major clades (the B. calcarata and the B. steinbachi clades), defined by the following combination of character states: (1) truncate snout in dorsal view; (2) rounded head shape; and (3) presence of calcaneal appendage on heel.

The B. calcarata clade (Fig. 1) is composed of four species possessing a calcar and having advertisement calls formed by a single type of call (Caminer \& Ron, 2014). The B. steinbachi clade, on the other hand, includes three described and two undescribed species (Fig. 1). Members of this clade lack a calcar (skin flap or tubercle present, or the complete absence of calcaneal appendages) and have vocal repertoires composed of more than one type of call, except for B. alfaroi for which a single type of call has been documented so far (Caminer \& Ron, 2014).

Hyla steinbachi Boulenger, 1905, currently valid as Boana steinbachi (Boulenger, 1905), was described from the Bolivian Province Sara, Departament Santa Cruz de la Sierra, Bolivia. We assume that Buenavista is the type locality of B. steinbachi. Between 1910 and 1950 the Steinbach family collected many amphibians and reptiles in Bolivia, mainly at Buenavista in the Department of Santa Cruz (see Parker, 1927), which is the type locality of several anurans (Hamptophryne boliviana (Parker, 1927); Pseudopaludicola boliviana Parker, 1927; Scinax parkeri (Gaige, 1929)), and the snake Apostolepis tenuis Ruthven, 1927. The material collected by the Steinbach family is on display in various museums, such as the University of Michigan Museum of Zoology (UMMZ, see Gaige, 1929), the Natural History Museum, London (BMNH, see Parker, 1927), the Zoologisches Museum Berlin (ZMB, see Müller, 1924), and the Naturhistorisches Museum Basel (NBM, pers. comm. Wüest). Many decades later, De la Riva (1990) synonymized $H$. steinbachi with $H$. fasciata. Subsequently, Jansen, Bloch, Schulze, and Pfenninger (2011) found differences in call and mtDNA data between populations of $B$. fasciata from Bolivia and Ecuador and suggested that their results imply a resurrection of $B$. steinbachi. In the following years, Caminer and Ron (2014) tentatively assigned B. steinbachi to a genetic lineage (clade J) inhabiting Bolivian Amazonia, near its type locality. By assessing its phylogenetic relationships in the group, Caminer and Ron (2014) formally revalidated $B$. steinbachi as a distinct species from nominal B. fasciata. The revalidation of $B$. steinbachi was also supported by phenotypic data obtained from syntypes but did not include a reexamination of all diagnostic characters of the species.

Next, we present an amended diagnosis of B. steinbachi based on novel data on life colours and morphology, and describe its vocal repertoire based on topotypes from Bolivia and distinct OTUs from Peru and Brazil 

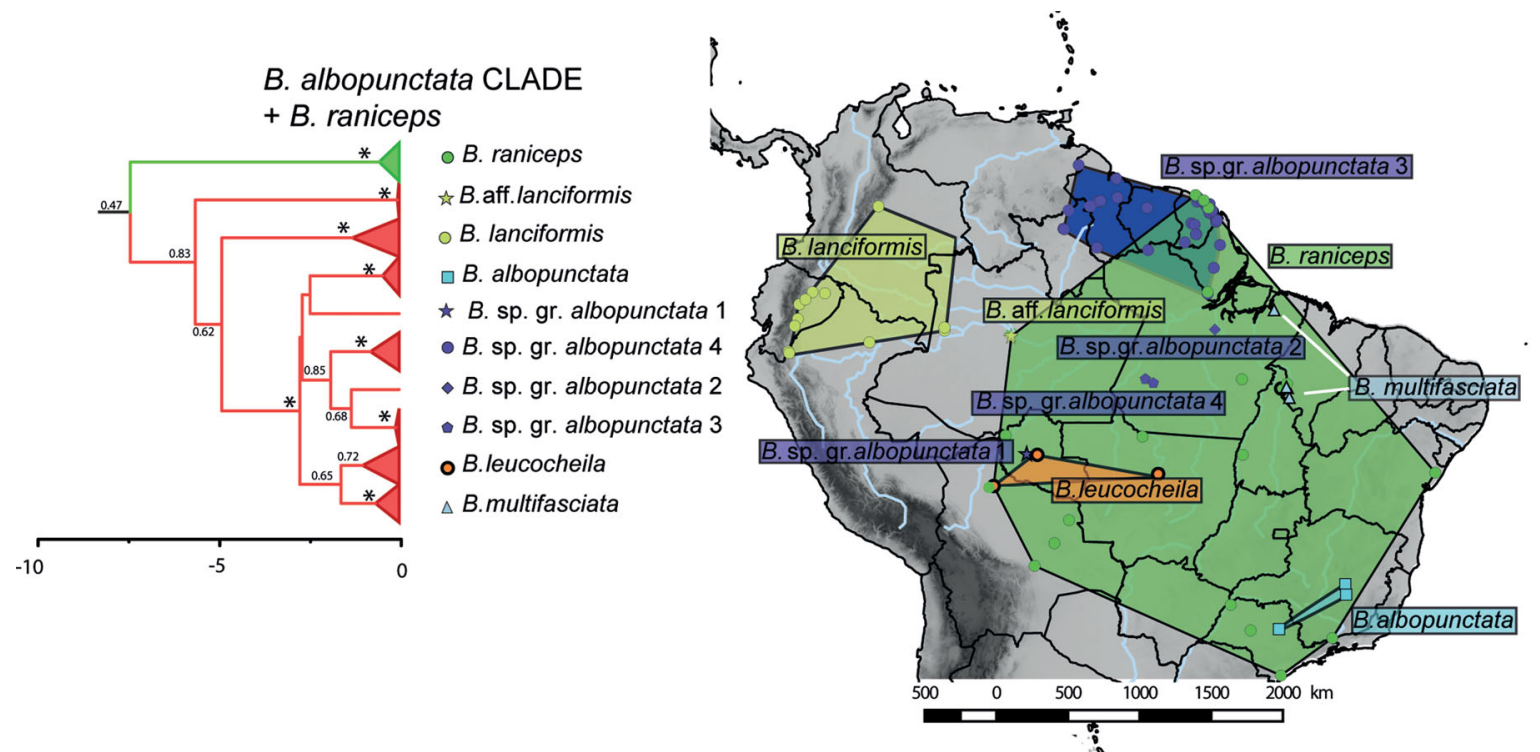

B. calcarata CLADE

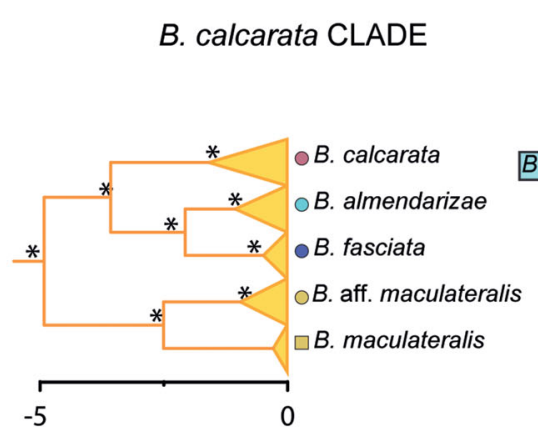

B. steinbachi CLADE

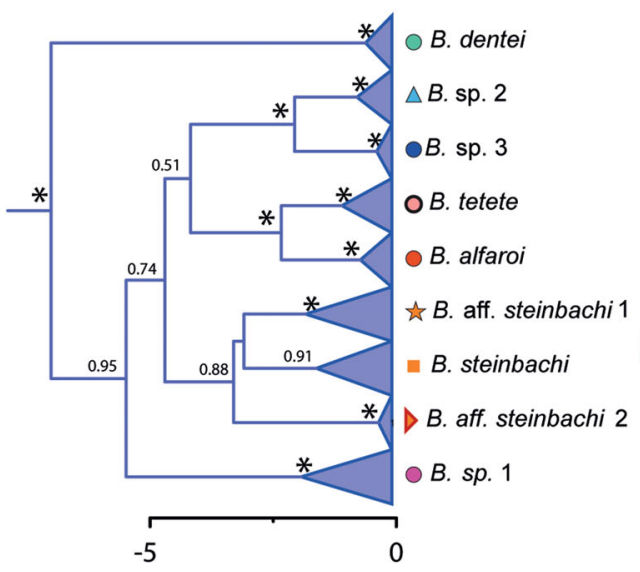

\section{COLOR \\ Online \\ B \&W in
Print}
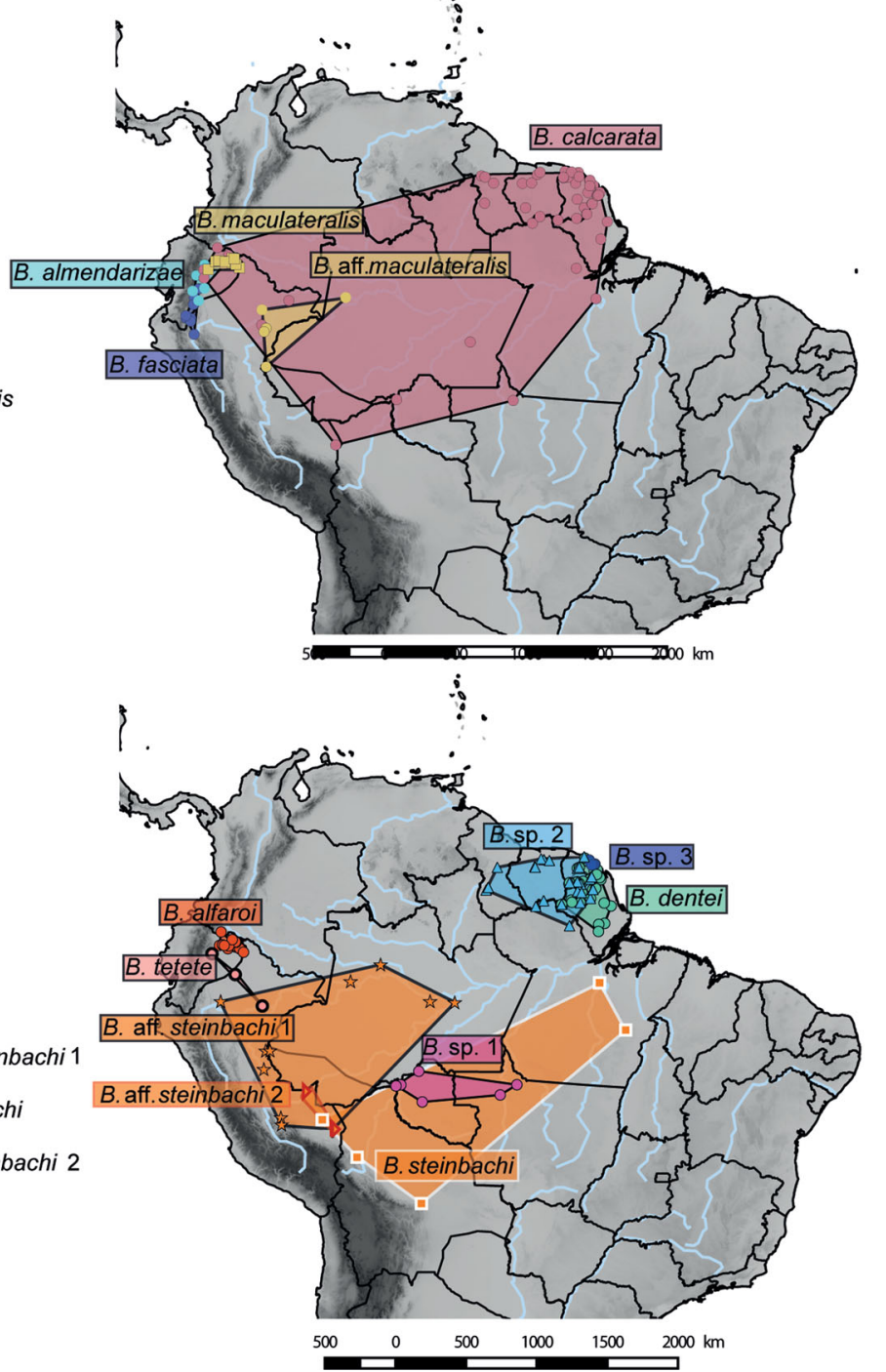

Fig. 1. Subtrees of the three main clades from the chronogram obtained from the analysis of $16 \mathrm{~S}$ sequences using BEAST2. Terminals are collapsed according to the OTU recovered from the species delineation analysis. The distribution of each of these OTU is depicted on the maps. 
also assigned to this species in this study. Specimens and calls from Acre ("B. aff. steinbachi 1") and calls from the lower Madre de Dios River (" $B$. aff. steinbachi 2 ") were included in the variation of B. steinbachi.

Boana steinbachi (Boulenger, 1905)

Hyla steinbachi — Boulenger, 1905

Hyla fasciata De la Riva, 1990

Hypsiboas fasciatus Jansen et al., 2011

Hypsiboas sp. (Clade G) Funk et al., 2012

Hypsiboas steinbachi Caminer \& Ron, 2014

Boana steinbachi Dubois, 2017.

Boana sp. (Clade J) Meza-Joya et al., 2019

Boana fasciata Vacher et al. 2020

Syntypes. BMNH 1947.2.13.61-63, two adults of unknown sex and one juvenile, respectively, from Sara province, Department of Santa Cruz de La Sierra, Bolivia. Collected by Hf. J. Steinbach.

Diagnosis. Boana steinbachi is characterized by the following combination of character states: (1) skin flap on heel; (2) vocal repertoire composed of more than one call type; (3) multinote call; and (4) regular internote intervals (Figs 2, $3 \& 4$ ).

Comparisons with congeners of the Amazonian clade. Boana steinbachi can be distinguished from the members of the B. calcarata clade (B. almendarizae, B. fasciata, B. calcarata, and $B$. maculateralis) by the absence of a calcar and by the vocal repertoire composed of more than one type of call. Among members of the B. steinbachi clade, it can be distinguished from $B$. dentei, B. alfaroi, and $B$. tetete by the presence of a skin flap on heel (tubercle in $B$. alfaroi and $B$. tetete; tubercle on one side or completely absent in $B$. dentei), by its multinote call (onenote call in $B$. dentei and $B$. tetete), by having regular internote intervals between call notes (notes with irregular intervals, sometimes partly fused one with the next in $B$. alfaroi), and by the vocal repertoire composed of two distinct types of calls (one call type in B. alfaroi) (Caminer \& Ron, 2014; Marinho et al., 2020).

Variation. Body size varies between 30.4 and $37.4 \mathrm{~mm}$ in males and between 42.5 and $48.8 \mathrm{~mm}$ in females (Appendix 7). Individual AAG-UFU 5918 lacks the heel skin flap on the left side, topotypes SMF 88394-95 and SMF 88397 lack the skin flap on both sides. In life (Fig. 3a, b), dorsal colouration is beige, light brown, bright yellow or orange brown in calling males, with faint brown transversal bands and dark purplish-brown, faint brown or grey longitudinal lines extending from

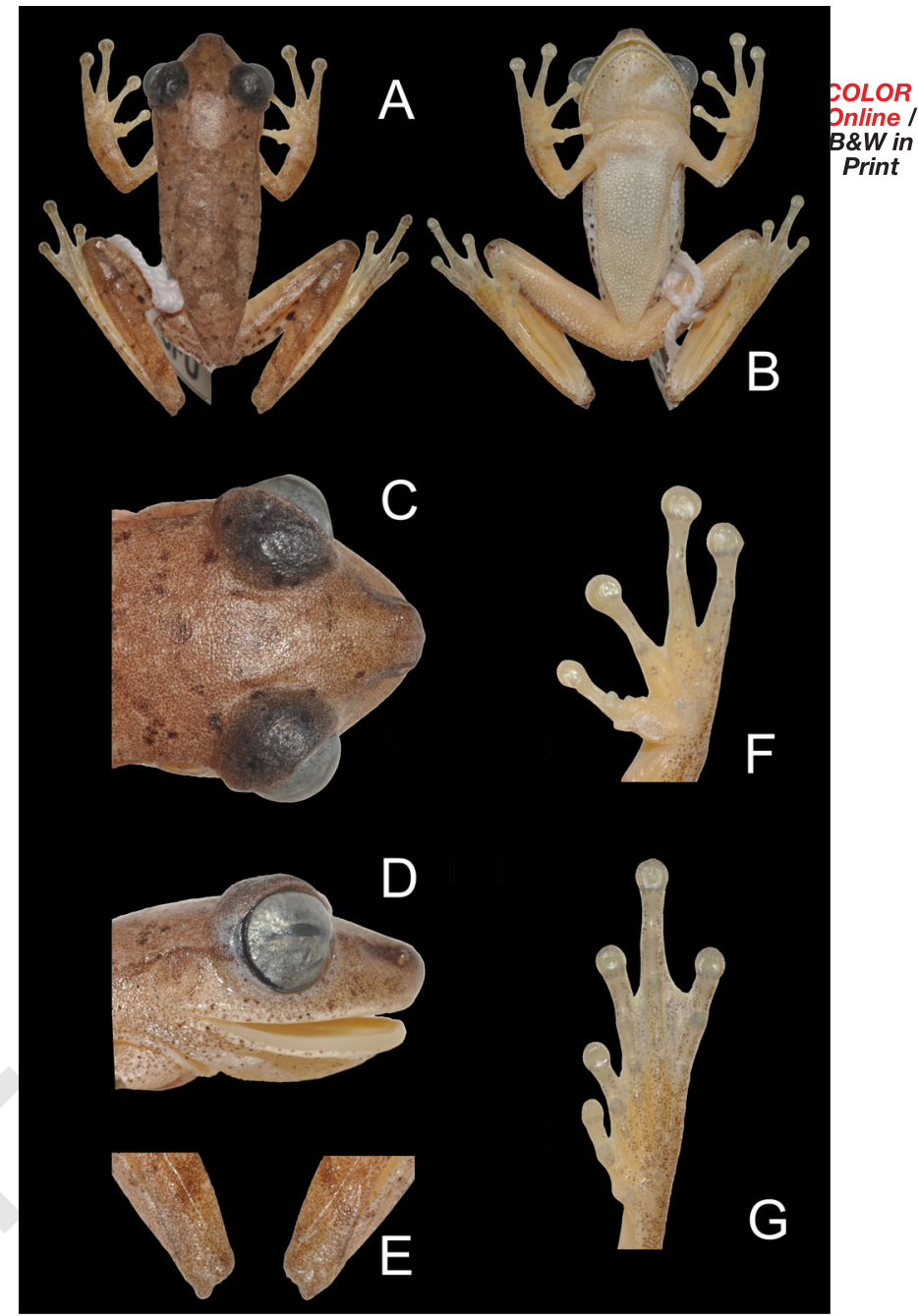

Fig. 2. Adult male of Boana steinbachi (AAG-UFU 5921) from the Assis Brasil population (Acre, Brazil): (A) dorsal and (B) ventral views of the body $(\mathrm{SVL}=33.7 \mathrm{~mm})$, (C) dorsal and (D) lateral views of the head (HL $=12.3 \mathrm{~mm}$; HW $=$ $10.2 \mathrm{~mm}$ ), (E) detail in dorsal view of the skin flap on heels, (F) palm of the hand $(\mathrm{HAL}=10.6 \mathrm{~mm})$, and $(\mathrm{G})$ sole of the foot $(\mathrm{FL}=13.9 \mathrm{~mm})$.

the snout to vent, a second line extending from behind the eye to pelvic region, and a third line as a canthal stripe extending from the posterior corner of the nostril to anterior corner of the eye, and from the posterior corner of the eye to midbody length on flank (the topotypes SMF 88394-97 lack transversal bands on dorsum; individuals SMF 88394 and CORBIDI 13414 lack longitudinal lines on dorsum and the middorsal line is extending from snout to interocular region; AAG-UFU 5921 lacks longitudinal lines on dorsum). Iris cream or grey, sometimes with yellow pigmentation on the upper part of the iris. Throat varying from white to yellow, chest and anterior belly varying from white to cream. Ventral surface of hand and hind limb beige to bright 

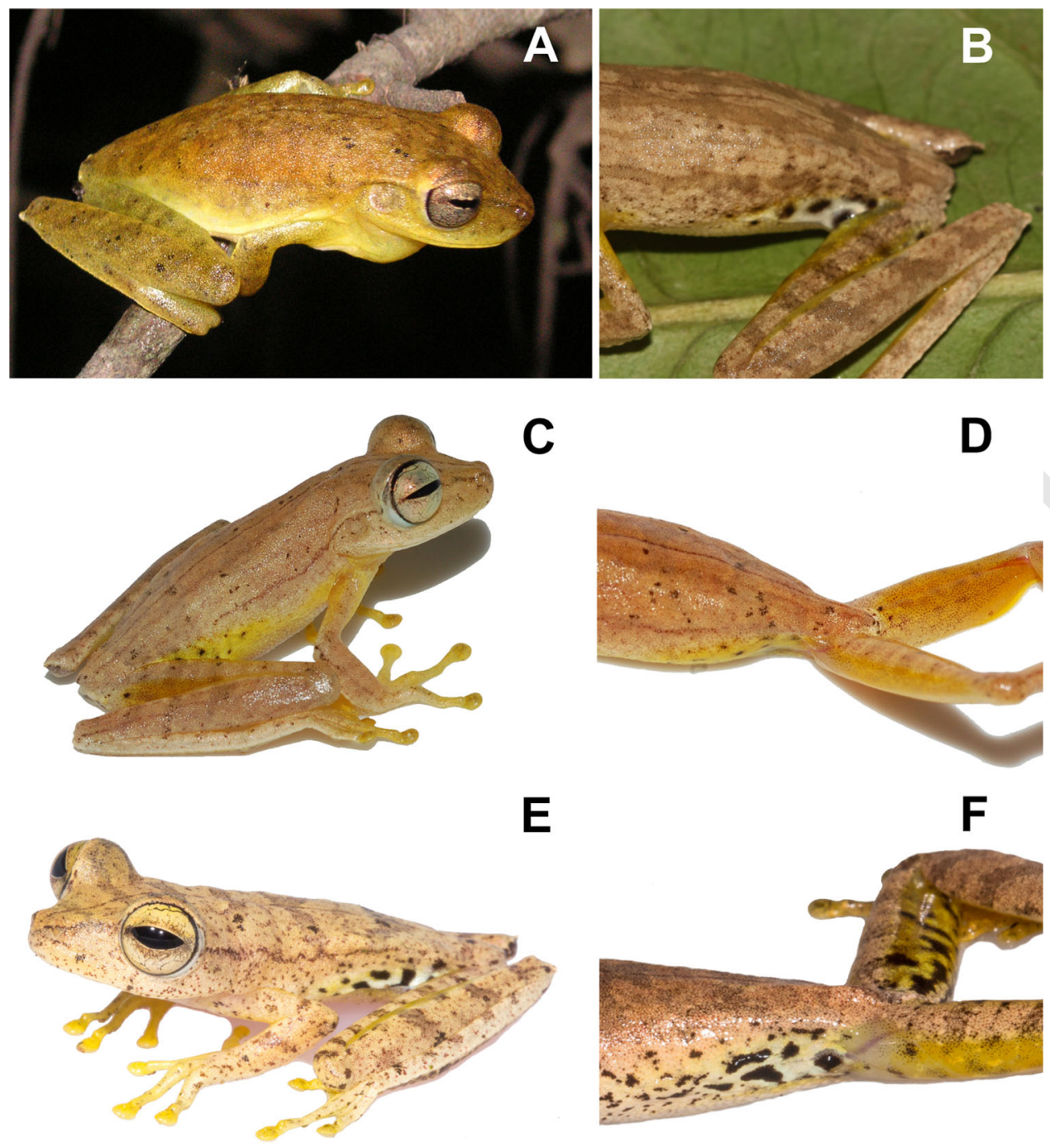

Fig. 3. Life colours in dorsolateral view and detail of the patterns on flank and groin. (A, B) Boana steinbachi (topotype SMF88394 and non-topotype AAG-UFU 5918, respectively), (C, D) B. eucharis sp. nov. (AAG-UFU 6503; holotype), and (E, F) B. courtoisae sp. nov. (holotype, MNHN-RA-2020.0001, and an unvouchered specimen, respectively).

yellow. Posterior surface of thigh, groin and posterior half of flank spotted in black, with a bright yellow or white background colour. Brown dots scattered on dorsum, dorsal surface of limbs, bordering the lower lip, mental region, and chest. In preservative, the colours fade: the bright yellow colour sometimes present on dorsum, ventral surfaces of limbs, groin, and flank are beige or pale cream. Iris grey. Flank and groin maculation are denser and more extensive in females.

Vocal repertoire. (Fig. 4) We analysed calls of 13 males (see Appendix 4 for information about sound recordings and Appendix 6 for the complete descriptive statistics). The vocal repertoire of Boana steinbachi is composed of two distinct types of calls (type 1: $n=149$ calls of 13 males; type $2: \mathrm{n}=43$ calls of five males) that are emitted sporadically at irregular intervals. The type 1 call of $B$. steinbachi lasts $130-430 \mathrm{~ms}$ and is composed of 3-8 nonpulsed notes lasting 4-52 ms, separated by intervals of $1-67 \mathrm{~ms}$. The rise time is at $2-98 \%$ of call duration. The minimum frequency ranges from $1335-1981 \mathrm{~Hz}$, the maximum frequency from $3336-4479 \mathrm{~Hz}$, and the dominant frequency from $1688-3402 \mathrm{~Hz}$. The type 2 call is composed of one note with poorly defined pulses. Notes last $47-87 \mathrm{~ms}$. The rise time is at $18-60 \%$ of note duration. The minimum frequency ranges from $1453-2015 \mathrm{~Hz}$, the maximum frequency from $2713-4522 \mathrm{~Hz}$, and the dominant frequency from $1688-2813 \mathrm{~Hz}$. The limited sample size for each population with recorded calls prevented us from evaluating the geographic variation of acoustic traits across populations of $B$. steinbachi. 
CALL TYPE 1
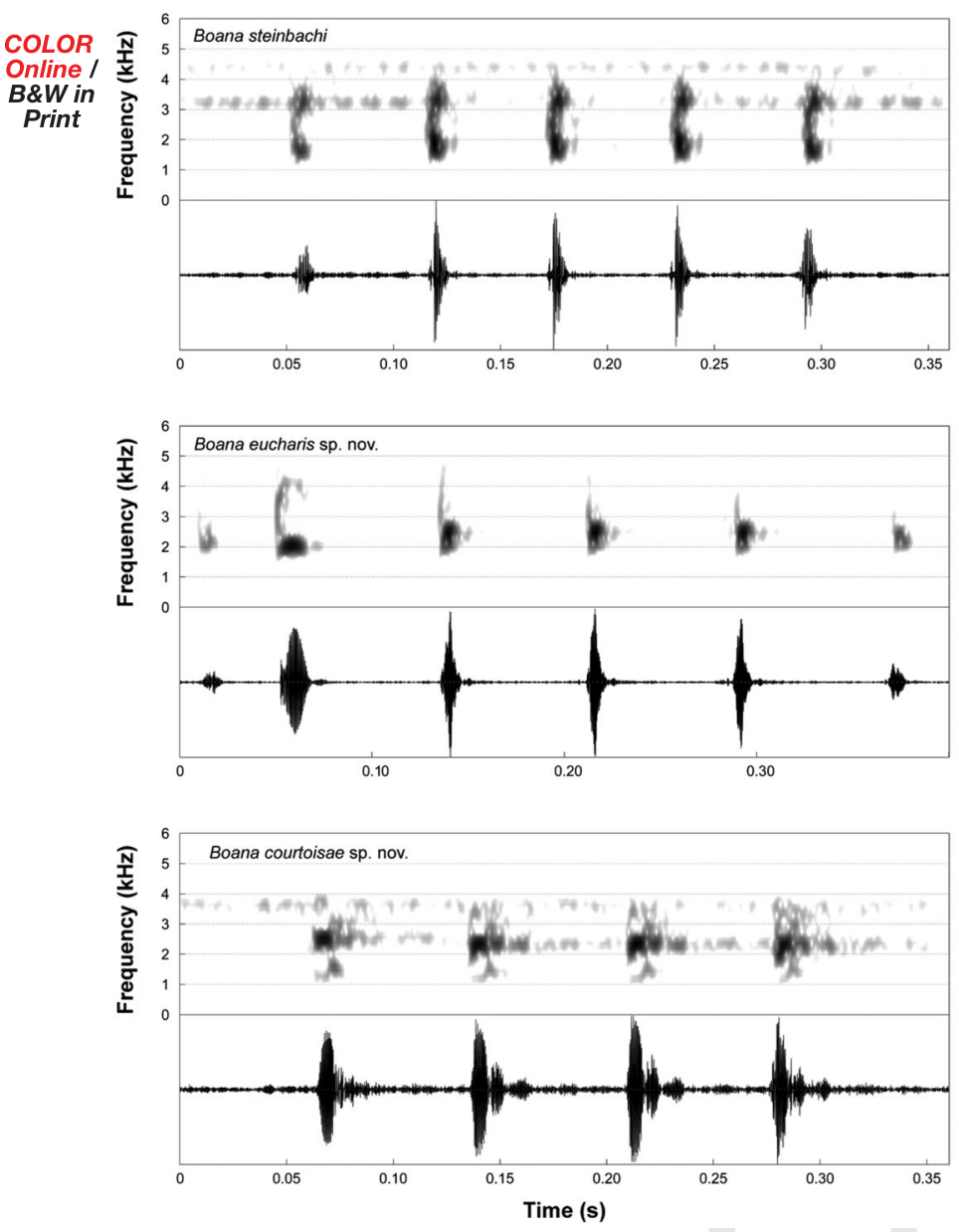

CALL TYPE 2
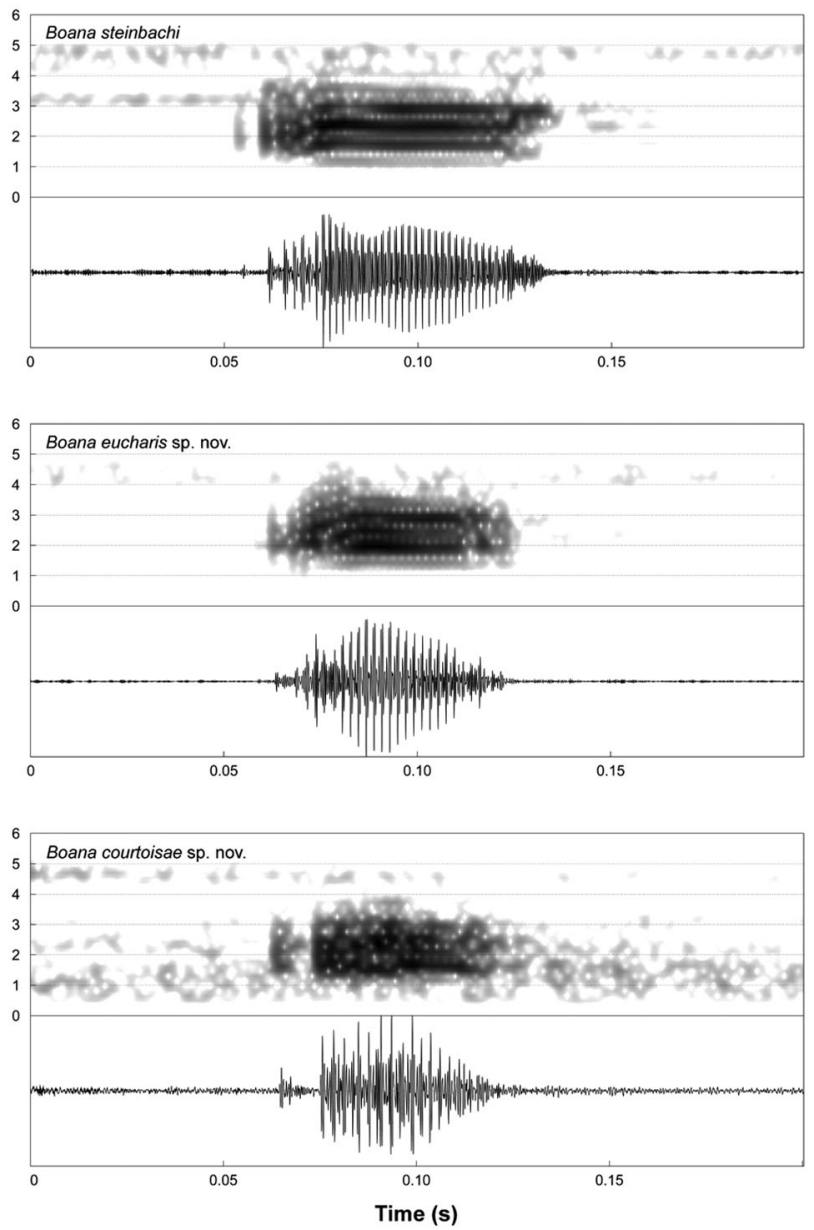

Fig. 4. Type 1 (left) and type 2 (right) calls (spectrograms and corresponding oscillograms) of B. steinbachi (Top; accession number MNHN-SO-2020-2934); B. eucharis sp. nov. (Middle; file: B_eucharisAltaFlorestaMT5hPM_AAGm671; MNHN-SO-2020-2969); and B. courtoisae sp. nov. (Bottom; MNHN-SO-2020-2947). See Appendix 4 for additional information on sound recordings.

Distribution and ecology. In addition to the type locality in central Bolivia, occurrence records of B. steinbachi, based on molecular and phenotypic data, encompass the south-western, central, and eastern Brazilian Amazonia (Acre, Amazonas, and Pará; Fig. 1), and south-western Peruvian Amazonia (Tambopata and the lower Madre de Dios River). Collected males were calling perched on shrubs in the periphery of flooded areas and in forest clearings of secondary Amazonian lowland forests. Its range is extensive and encompasses numerous protected areas. Moreover, the species seems to tolerate habitat disturbance. Therefore, its status should be considered of Least Concern.

Boana eucharis sp. nov.

Hypsiboas fasciatus Ávila \& Kawashita-Ribeiro, 2011 Hypsiboas fasciatus Rodrigues et al., 2015
Boana fasciata Vacher et al. 2020

Holotype. AAG-UFU 6503, adult male collected from the municipality of Alta Floresta, Mato Grosso state, Brazil $\left(-9.642839^{\circ},-56.271408^{\circ}\right)$ by Davi L. Bang, André G. Lopes, and Pedro Marinho on 11 January 2019 (Fig. 3 \& 5).

Paratopotypes. Five adult males (AAG-UFU 6504-6508) collected with the holotype. AAG-UFU 6904, adult male collected on 20 January 2020 by Ariovaldo A. Giaretta, Pedro Marinho, and André G. Lopes.

Paratypes. ( 1 male, 4 females). MZUSP 143323, adult male and MZUSP 143324, adult female, collected at UHE Jirau, Abunã, state of Rondônia, Brazil 
one call type; (3) multinote call; and (4) regular internote intervals (Figs 3, 4 \& 5).

Comparisons with congeners of the Amazonian clade. Boana eucharis sp. nov. is distinguished from the members of the $B$. calcarata clade (B. almendarizae, B. fasciata, $B$. calcarata, and $B$. maculateralis) by the absence of a calcar and by the vocal repertoire composed of more than one type of call. Within the B. steinbachi clade, $B$. eucharis sp. nov can be distinguished from $B$. dentei, and $B$. tetete by its multinote call (onenote calls in $B$. dentei and $B$. tetete), and from $B$. alfaroi by having regular internote intervals and vocal repertoire composed of two distinctive types of calls (in B. alfaroi, call notes having irregular intervals, sometimes partly fused one with the next, and repertoire formed by one call type; Caminer \& Ron, 2014; Marinho et al., 2020). Boana eucharis sp. nov. can be distinguished in almost all cases from $B$. steinbachi by the presence of tubercle on heel (skin flap in B. steinbachi; but see Variation). In addition, $B$. eucharis sp. nov. is sister of all remaining species of the $B$. steinbachi clade (except the allopatric $B$. dentei). The phylogenetic relationships within this clade and spatial distribution strongly support the distinct specific status of $B$. eucharis sp. nov. relative to its closest relatives (Fig. 1).

Description of holotype. (Figs $3 \&$ 5) Adult male, SVL $30.8 \mathrm{~mm}$, FL $12.0 \mathrm{~mm}$, ED $3.8 \mathrm{~mm}$, TD $2.0 \mathrm{~mm}$, TL $17.8 \mathrm{~mm}$, THL $15.8 \mathrm{~mm}$, CL $0.2 \mathrm{~mm}$, HAL $10.4 \mathrm{~mm}$, FLL $5.9 \mathrm{~mm}$, EN $3.3 \mathrm{~mm}$, head slightly longer (HL $11.9 \mathrm{~mm}$ ) than wide (HW $10.3 \mathrm{~mm}$ ), and wider than body; snout rounded in lateral view, truncate in dorsal view; EN shorter than ED; canthus rostralis indistinct, rounded; loreal region concave; internarial area convex; nostril slightly protuberant, directed laterally; interorbital area slightly convex; eye large, strongly protuberant; ED 1.9 times TD; tympanic membrane undifferentiated; tympanic annulus evident, rounded, concealed posteriorly by the supratympanic fold, running from the posterior corner of the eye to arm insertion. Tongue ovoid, widely attached to mouth floor; six vomerine teeth on each vomer, vomers barely separated, posteromedial to choanae; choanae ovoid. Arm slender, axillary membrane absent; ill-defined, low tubercles present along ventrolateral edge of forearm; relative length of fingers I $<$ II $<$ IV $<$ III; fingers bearing large, oval discs; subarticular tubercles prominent, ovoid to conical, single; supernumerary tubercles present; palmar tubercle small, elongated; prepollical tubercle large, flat, elliptical; prepollex enlarged, covered by skin; nuptial excrescences absent; webbing absent between fingers. Tubercle on tibiotarsal articulation; scattered tubercles along the the following combination of character states: (1) tubercle on heel; (2) vocal repertoire composed of more than 
external edge of tarsus and foot; toes bearing discs slightly wider than long, smaller than those of fingers; relative length of toes $\mathrm{I}<\mathrm{II}<\mathrm{V}<\mathrm{III}<\mathrm{IV}$; outer metatarsal tubercle ill-defined, small, rounded; inner metatarsal tubercle large, ovoid; subarticular tubercles single, low, rounded; supernumerary tubercles restricted to the sole of foot; webbing formula of toes I $2-2^{1 / 2}$ II $1^{+}-2^{1 / 2}$ III $1^{1 / 2}-2^{1 / 2}$ IV $3-1^{1 / 2} \mathrm{~V}$. Skin on dorsum, head, and dorsal surfaces of limbs and flank mostly smooth; skin on belly and thigh coarsely granular; skin on throat and chest finely granular, arm, forearm, and shank smooth. Cloacal opening directed posteriorly at upper level of thigh; short simple cloacal sheath covering cloacal opening; round tubercles below and on the sides of the opening.

Colours of holotype. In preservative, dorsum greyish brown with scattered minute black dots; faint brown middorsal line extending from the tip of the snout to pelvic region, fragmented in interorbital region, a second line extending from behind the eye to pelvic region, fragmented and faint at midbody length, and a third line as a canthal stripe extending from the posterior corner of the nostril to anterior corner of the eye, and from the posterior corner of the eye to midbody length on flank; dorsal surface of limbs greyish brown with transversal faint brown bars; flank beige with dark irregular spots; posterior surface of thigh beige with dark irregular spots; venter cream white with brown spots on the mental region and chest; ventral surface of limbs cream with a narrow brown stripe on the outer edge of the hand, forearm, thigh, tarsal fold, and foot; limb bones partially visible through skin, white. In life (Fig. 3c, d), dorsum beige with a purplish brown middorsal line extending from the tip of snout to pelvic region, a second line extending from behind the eye to pelvic region, fragmented and faint at midbody length, and a third as canthal stripe from the posterior border of nostril to anterior corner of the eye, and from the posterior corner of the eye to midbody length on flank; dorsal surface of hindlimbs with faint brown transversal bands; minute dark brown dots scattered on the dorsal surface of limbs and dorsum; flank bright yellow with dark brown irregular blotches on groin; posterior surface of thigh pale yellowish with dark brown blotches.

Variation. Body size varies between 30.8 and $34.7 \mathrm{~mm}$ in males (Appendix 7). The paratopotype AAG-UFU 6504 lacks the heel tubercle on the right side, and MZUSP 80790 (from Rondônia) does not possess the tubercle on either side. In life (Fig. 3c, d), dorsal colouration varies from beige to brown, orange brown in calling males, with dark purplish-brown longitudinal lines and faint brown transversal bands (individuals MZUSP
159227 and MZUSP 159228 do not have longitudinal lines extending from snout to pelvic region or a canthal stripe). Throat varies from white to yellow, chest and anterior belly varying from white to cream. Iris cream or grey, sometimes with yellow pigmentation on the upper iris. Ventral surface of hand and hind limb mostly bright yellow. Posterior surface of thigh, groin and posterior half of flank spotted in black, with a bright yellow or white background colour. Brown dots scattered on dorsum, dorsal surface of limbs, bordering the lower lip, mental region, and chest. We did not observe dichromatic patterns between male and female specimens. In preservative, the colours become paler: the bright yellow tone occasionally on ventral surfaces of limbs, groin and flank is beige or pale cream. Iris grey.

Vocal repertoire. Calls of seven males were recorded at the type locality, in southern Brazilian Amazonia (Appendix 6). The vocal repertoire of Boana eucharis is composed of two distinct calls (type 1: $n=133$ calls from seven males; type $2: n=62$ calls from seven males) that are emitted sporadically at irregular intervals. The type 1 call (Fig. 4) lasts 290-420 ms and consists of 3-7 nonpulsed notes that last $3-60 \mathrm{~ms}$, separated by intervals of $27-82 \mathrm{~ms}$. The rise time is at $2-97 \%$ of call duration. The minimum frequency ranges from $1864-2250 \mathrm{~Hz}$, the maximum frequency from $2196-4220 \mathrm{~Hz}$, and the dominant frequency from $2147-2462 \mathrm{~Hz}$. The type 2 call consists of one note with poorly defined pulses. Notes last 29-64 ms. The rise time is at $24-78 \%$ of note duration. The minimum frequency ranges from $1593-2067 \mathrm{~Hz}$, the maximum frequency from $2712-3491 \mathrm{~Hz}$, and the dominant frequency from $1938-3143 \mathrm{~Hz}$.

Distribution and ecology. Boana eucharis sp. nov. is known from southern Amazonia in the Brazilian states of Mato Grosso and Rondônia (Fig. 1). Males call perched on shrubs in flooded areas associated with the border of secondary-growth or disturbed forests. Sympatric anuran species at the type locality of $B$. eucharis sp. nov. are Boana leuchocheila, B. albopunctata, Dendropsophus cruzi, Engystomops freibergi, Leptodactylus vastus, L. petersii, Pithecopus hypochondrialis, Scinax garbei, and S. nebulosus. The species is not abundant. It is possible that the species range is more extensive than the five populations reported in this study, which suggests a Data Deficient conservation category for B. eucharis sp. nov. However, it is important to highlight that the southern limits of Amazonia are overall highly impacted by habitat conversion and this species could be classified at least as Vulnerable. Nevertheless, the known occurrence recordings comprise at least two protected conservation units: Pacaás Novos 
National Park and possibly the Cristalino State Park, and the species seems to tolerate a certain extent of human disturbance to forest habitats, since calling males were sampled at forest borders and clearings.

Etymology. The specific epithet is derived from the Greek word eukharis, which means gracious or charismatic, as a reference to the delicate and gracious aspect of the species.

Boana courtoisae sp. nov.

Hyla fasciata Lescure \& Marty, 2000

Hyla fasciata Faivovich et al., 2005

Hypsiboas fasciatus Fouquet et al., 2007

Hyla fasciata Avila-Pires et al, 2010

Hypsiboas sp. (Clade H) Funk et al., 2012

Hypsiboas fasciatus Ouboter \& Jairam, 2012

Hypsiboas fasciatus Cole et al., 2013

Hypsiboas sp. (Clade H) Caminer \& Ron, 2014

Boana cf. fasciata Fouquet et al., 2019

Boana fasciata Vacher et al. 2020

Holotype. MNHN-RA-2v2v.0001 adult male, collected at Alikéné, French Guiana $\left(3.20906^{\circ},-52.402000^{\circ}\right)$ by J.P. Vacher and S. Cally on 12 February 2015 (Figs 3 \& 6).

Paratopotypes. An adult female (MNHN-RA2020.0002) collected with the holotype.

Paratypes. (12 males, 3 females). MNHN-RA2020.0004 adult male, collected at Saut Taconet, French Guiana $\left(4.03249^{\circ}, \quad-52.526188^{\circ}\right)$; $\quad$ MNHN-RA2020.0005 adult female, collected at Saut Grand Machicou, French Guiana $\left(3.897416^{\circ},-52.583565^{\circ}\right)$; MNHN-RA-2020.0006-7 two adult males, collected at Saul, French Guiana $\left(3.615576^{\circ},-53.227093^{\circ}\right)$; MNHN-RA-2020.0008 adult male, collected at Flat de la Waki, French Guiana $\left(3.089500^{\circ},-0^{\circ}, 398460^{\circ}\right)$; MNHN-RA-2020.0009-12 four adult males, collected at Sipaliwini, Suriname $\left(2.097530^{\circ}, \quad-56.147200^{\circ}\right)$; MNHN-RA-2020.0013 an adult male, collected at Ekini, French Guiana $\left(4.050000^{\circ},-52.466700^{\circ}\right)$; MNHN-RA2020.0014-16 three adult males, collected at Mitaraka, French Guiana $\left(2.235770^{\circ},-54.449280^{\circ}\right)$; MNHN-RA2020.0003 an adult female collected at Inini Tolenga, French Guiana $\left(3.663159^{\circ},-53.928308^{\circ}\right)$.

Other material. Twelve additional males and three females (Appendix 8) from French Guiana and Suriname were also assigned to $B$. courtoisae. They were examined and included in the analysis of the variation but were not deposited and not included in the type series.

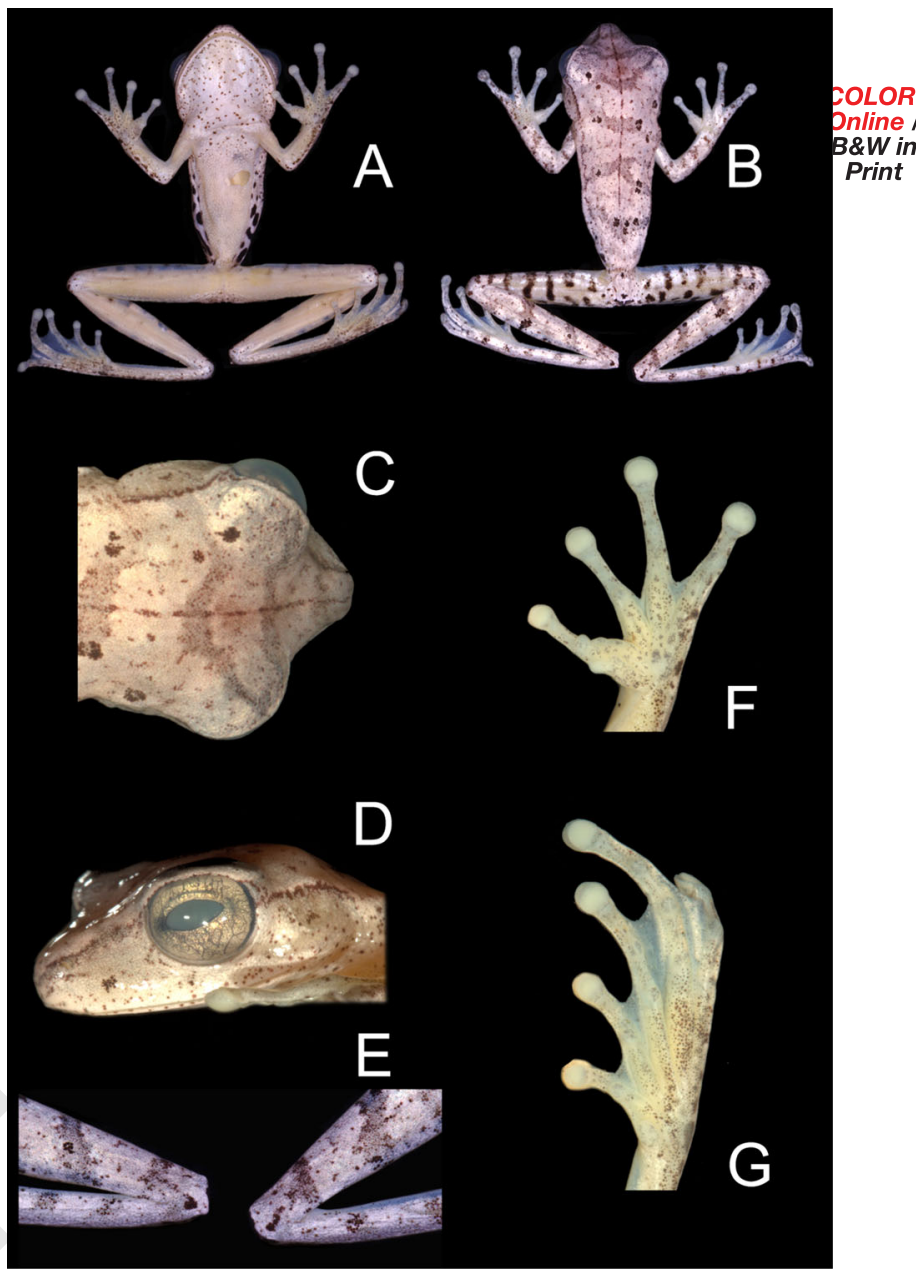

Fig. 6. Holotype of Boana courtoisae sp. nov. (MNHN-RA2020.0001) from Alikéné (French Guiana): (A) dorsal and (B) ventral views of the body ( $\mathrm{SVL}=31.0 \mathrm{~mm}$, adult male), (C) dorsal and (D) lateral views of the head ( $\mathrm{HL}=11.5 \mathrm{~mm}$; HW $=10.8 \mathrm{~mm}$ ), (E) detail in dorsal view of the skin flap on heels, (F) palm of the hand $(\mathrm{HAL}=9.3 \mathrm{~mm})$, and $(\mathrm{G})$ sole of the foot $(\mathrm{FL}=12.0 \mathrm{~mm})$.

Diagnosis. Boana courtoisae sp. nov. is characterized by the following combination of character states: (1) skin flap on heel; (2) vocal repertoire composed of more than one call type; (3) multinote call; and (4) regular internote intervals; (5) multi-blotched pattern on groin and flank of males (Figs 3, 4 \& 6).

Comparisons with congeners of the Amazonian clade. Boana courtoisae sp. nov. is distinguished from members of the $B$. calcarata clade (B. almendarizae, B. fasciata, $B$. calcarata, and $B$. maculateralis) by the absence of a calcar and by the vocal repertoire composed of more than one type of call. Within the B. steinbachi clade, $B$. courtoisae sp. nov. can be distinguished from $B$. dentei, and $B$. tetete by its multinote call (onenote calls in B. dentei and B. tetete), and from B. alfaroi 
by its regular internote intervals and vocal repertoire composed of two distinctive types of calls (in B. alfaroi, call notes having irregular intervals, sometimes partly fused one with the next, and repertoire formed by one call type) (Caminer \& Ron, 2014; Marinho et al., 2020). Boana courtoisae sp. nov. can be distinguished in almost all cases from $B$. eucharis sp. nov. by the presence of skin flap on heel (tubercle in B. eucharis sp. nov.; but see Variation). In addition, B. courtoisae sp. nov. can be distinguished from $B$. eucharis sp. nov. and B. steinbachi by a multi-blotched pattern on flank and groin of males (fewer blotches, or transversal bands and spots in males of the other two species; Fig. 3). Although B. courtoisae sp. nov. and B. eucharis sp. nov. are distinguished by subtle differences in morphology and colouration, the two species are not directly phylogenetically related to each other since $B$. courtoisae sp. nov. is sister of the remaining species that form the $B$. steinbachi clade (B. steinbachi, B. alfaroi, $B$. tetete, and $B$. eucharis sp. nov.), which strongly supports the distinct specific status relative to its closest relatives (Fig. 6).

Description of holotype. Adult male, SVL $31.0 \mathrm{~mm}$, FL $12.0 \mathrm{~mm}$, ED $4.4 \mathrm{~mm}$, TD $1.8 \mathrm{~mm}$, TL $18.9 \mathrm{~mm}$, THL $15.8 \mathrm{~mm}$, CL $0.4 \mathrm{~mm}, \mathrm{HAL}=9.3 \mathrm{~mm}$, FLL $6.2 \mathrm{~mm}$, EN $4.2 \mathrm{~mm}$, head slightly longer (HL $11.5 \mathrm{~mm}$ ) than wide (HW $10.9 \mathrm{~mm}$ ), and wider than body; snout rounded in lateral view, truncate in dorsal view (Fig. 5); EN shorter than ED; canthus rostralis indistinct, rounded; loreal region concave; internarial area convex; nostrils slightly protuberant, directed laterally; interorbital area slightly convex; eye large, strongly protuberant; ED 2.5 times TD; tympanum membrane undifferentiated; tympanic annulus evident, rounded, concealed posteriorly by supratympanic fold, running from the posterior corner of the eye to arm insertion. Tongue ovoid, widely attached to mouth floor; vomerine odontophores triangular with arched base, barely separated, posteromedial to choanae, bearing eight vomerine teeth on each side; choanae ovoid. Arm slender, axillary membrane absent; indistinct low tubercles present along ventrolateral edge of forearm; relative length of fingers I $<$ II $<$ IV $<$ III; fingers bearing large, oval discs, subarticular tubercles prominent, ovoid to conical, single; supernumerary tubercles present; palmar tubercle small, elongated; prepollical tubercle large, flat, elliptical; prepollex enlarged, claw shaped; nuptial excrescences absent; webbing absent between fingers. Skin flap on tibiotarsal articulation; scattered tubercles on tarsus and along ventrolateral edge of foot; toes bearing discs slightly wider than long, smaller than those of fingers; relative length of toes I $<$ II $<$ V $<$ III $<$ IV; outer metatarsal tubercle ill defined, small, round; inner metatarsal tubercle large, elongated and elliptical; subarticular tubercles single, low, rounded; supernumerary tubercles restricted to the sole of foot; webbing formula of toes $\mathrm{I} 2^{-} 2^{1 / 2} \mathrm{III} 1^{+}-2^{1 / 2} \mathrm{IIII} 1^{1 / 2}$ $2^{1 / 2} \mathrm{IV} 3-1^{1 / 2} \mathrm{~V}$. Skin on dorsum, head, and dorsal surfaces of limbs smooth; skin on flanks smooth with weak longitudinal wrinkles posterior to the arm; skin on venter coarsely granular; skin on ventral surfaces of head and thighs granular, those of shanks smooth. Cloacal opening directed posteriorly at upper level of thighs; short simple cloacal sheath covering cloacal opening; round tubercles below and on the sides of the opening.

Colour of holotype. In preservative, dorsum beige with scattered minute black dots and spots (Fig. 6); faint brown narrow middorsal line extends from the tip of the snout to the vent; faint brown transversal bands on dorsum; dorsal surface of limbs beige with transversal faint brown bars; flank white with dark irregular spots; posterior surface of thigh white with dark irregular blotches; venter creamy white with brown spots on the throat and chest; ventral surface of limbs whitish cream with scattered dots on the forearm; ventral surface of shank cream; a discontinuous brown stripe, varying in width along its length, on the outer edge of the hand and forearm, limb bones (visible through skin) white. In life, dorsum beige with a faint brown narrow longitudinal line from snout to vent; dorsal surface of limbs beige with faint brown transversal bands; scattered minute black dots on the dorsal surfaces of limbs and dorsum; flank white to light yellow with dark irregular blotches; venter white to cream; scattered brown flecks on the throat and chest, and bordering the lower lip; ventral surface of limbs pale yellow, with bright yellow granules; discs and webbing yellow; iris cream with an undefined upper yellow band; limb bones (visible through skin) white.

Variation. Body size varies between 30.8 and $35.9 \mathrm{~mm}$ in males and between 43.0 and $45.9 \mathrm{~mm}$ in females (Appendix 7). In life (Fig. 4e-f), dorsal colouration varies from beige to bright yellow or orange brown, with faint brown transversal bands markings, purplishbrown to dark brown longitudinal lines and many scattered brown spots covering all over the dorsum. Throat, chest, and anterior belly varying from white to cream with scattered spots covering the entire ventral surface in both sexes. Flank and groin with dark brown to black blotches on a bright yellow, bluish or white background. Ventral surface of hand, foot, and legs varying from bright yellow to dark grey, covered with black spots. Posterior surface of thigh striped or spotted in black with a bright yellow or white background colour, 
sometimes with tints of blue particularly pronounced in females (individual MNHN-RA-2020.0006 has no blotches or dots on the posterior surface of thigh or spots on belly). Iris grey or cream, sometimes with a yellow upper band (the individual MNHN-RA2020.0015 has also black markings surrounding the iris). Our collected individuals exhibit a dimorphic colouration between males and females. The ventral surface of thigh in males varies from bright yellow to greenish yellow. In females, the colouration of the ventral surface of thigh is blue, bluish grey or dark grey. The groin region, flank, and posterior surface of thigh have more tints of blue in females. In addition, flank and groin maculation is denser and more extensive in females. In preservative, the colours fade, becoming pale: the bright yellow tone sometimes present on dorsum is beige or brown with brown transversal bands and lines. Ventral surfaces of body, limbs, groin and flank are beige or pale cream. The blue tints on groin, flank and posterior surface of thigh completely vanish, as well as the dark blue or grey colours on ventral surfaces of female's thigh. Iris grey.

Vocal repertoire. Calls of five males were recorded from French Guiana and Suriname. The vocal repertoire of $B$. courtoisae is composed of two types of call (type $1: \mathrm{n}=13$ calls from five males; type $2: \mathrm{n}=5$ calls from three males) that are emitted sporadically at irregular intervals. The type 1 call (Fig. 4) lasts $140-240 \mathrm{~ms}$, consisting of 3-4 nonpulsed notes that last 5-36 ms, separated by intervals of $27-82 \mathrm{~ms}$. The rise time is at $2-97 \%$ of call duration. The minimum frequency ranges from 1335-1875, the maximum frequency from $2627-3101 \mathrm{~Hz}$, and the dominant frequency from 1981-2972 Hz. The type 2 call consists of one note with poorly defined pulses. Notes last $39-79 \mathrm{~ms}$. The rise time is at $39-82 \%$ of note duration. The minimum frequency ranges from $1464-1723 \mathrm{~Hz}$, the maximum frequency from $2713-3144 \mathrm{~Hz}$, and the dominant frequency from $1680-2412 \mathrm{~Hz}$.

Distribution and ecology. Boana courtoisae sp. nov. is distributed throughout the eastern Guiana Shield in French Guiana, Suriname, Guyana and adjacent Brazilian Amazonia in the states of Amapá, Pará (ÁvilaPires et al., 2010), and possibly Roraima (pending confirmation) The species could possibly occur in the state of Amazonas as well. The species is not abundant and found in scattered populations. Nevertheless, its range is extensive and encompasses numerous protected areas. Moreover, the species seems to tolerate habitat disturbance, indicated by the use of forest borders and clearings. Therefore, the conservation status of $B$. courtoisae sp. nov. might be classified as Least Concern (pending a formal evaluation by IUCN team). It is a nocturnal species found in primary and secondary forest associated with the flooded zones of slow streams and mediumsized rivers. The males call perched at low height on the adjacent vegetation or even overlooking the water forming small groups of 2-10 individuals separated by a few metres from each other. A single clutch was observed at Mitaraka, French Guiana and contained approximately 1,100 beige eggs deposited directly in the water and forming a film on the surface.

Etymology. This species is dedicated to our friend Elodie Courtois, in honour of her invaluable contribution to field herpetology in French Guiana, notably the monitoring of populations of threatened species and discovery of previously undocumented species and many natural history observations.

\section{Mitogenomic phylogeny}

The mitogenomic phylogeny is well resolved with the exception of the position of the clade formed by $B$. cinerascens $+B$. punctata and the position of $B$. pellucens within the genus (Fig. 7). Within the focal species group only the relationships among the different OTUs of the B. albopunctata clade remain ambiguous. Boana heilprini is strongly supported as the sister species of all other members of the B. albopunctata species group whose crown age is estimated to date back to $17.3 \mathrm{Ma}$ (14.4-20.2). Boana raniceps forms a clade with all the other species of the group whose crown age is estimated to date back to $13.2 \mathrm{Ma}$ (11.1-15.5). The remainder of species forms three main clades. The B. albopunctata clade diverges from the Amazonian species $\sim 10.9 \mathrm{Ma}$ (9.1-12.7). The two Amazonian clades diverged $\sim 9.9$ Ma (8.3-11.6).

\section{Biogeographic inferences}

Model comparisons identified DEC $+\mathrm{J}$ as the best-fit model (Appendix 9). According to both DEC and $\mathrm{DEC}+\mathrm{J}$ models the ancestral range of the $B$. albopunctata species group remains largely ambiguous since each of the major lineages is widely distributed in Amazonia and even further for the B. albopunctata clade. However, the ancestral range of the B. steinbachi clade is supported to be located in the Guiana Shield by the DEC $+\mathrm{J}$ model (Fig. 8A); and while it remains ambiguous for the DEC model, all states with high likelihood encompass the Guiana Shield (Fig. 8B). This group probably dispersed southward to the Brazilian Shield $\sim 5 \mathrm{Ma}$, as suggested by the phylogenetic position 


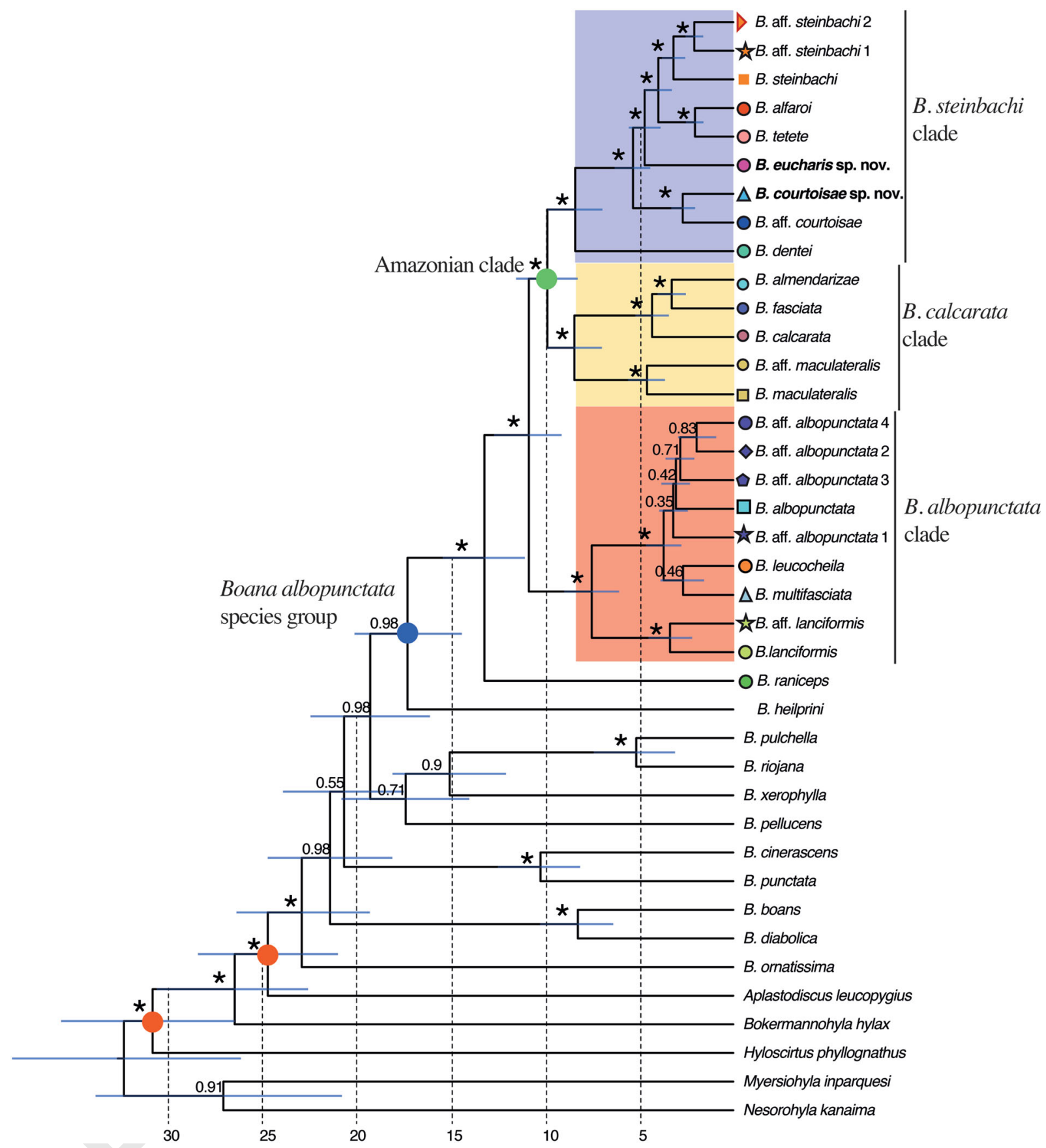

Fig. 7. Time calibrated tree inferred from the analysis of mitogenomic data in BEAST2 Nodes with maximum posterior probability (0.99 and 1) are indicated with an asterisk. Calibrated nodes are indicated with a red circle. The blue and the green circles point at major clades mentioned in the text. Node bars indicate the $95 \%$ highest posterior distributions of node dates. Symbols on the tips of the trees are the same as those used to indicate the geographic distribution of sampled species.

and range of B. eucharis (Fig. 8). Subsequent dispersal from the Brazilian Shield toward western Amazonia is suggested by the nested position of the clade formed by B. tetete, B. alfaroi, B. steinbachi and related OTUs. The occurrence of B. steinbachi in eastern Amazonia probably resulted from an even more recent dispersal toward the east (Pará state) from Western Amazonia
(Fig. 8A, B). Mirroring that situation, the ancestral range of the $B$. calcarata clade is inferred in western Amazonia where it has exclusively diversified except for a single and recent dispersal of $B$. calcarata eastward throughout Amazonia.

The ancestral range of the B. albopunctata clade remains ambiguous since it also displays an east vs. west pattern 


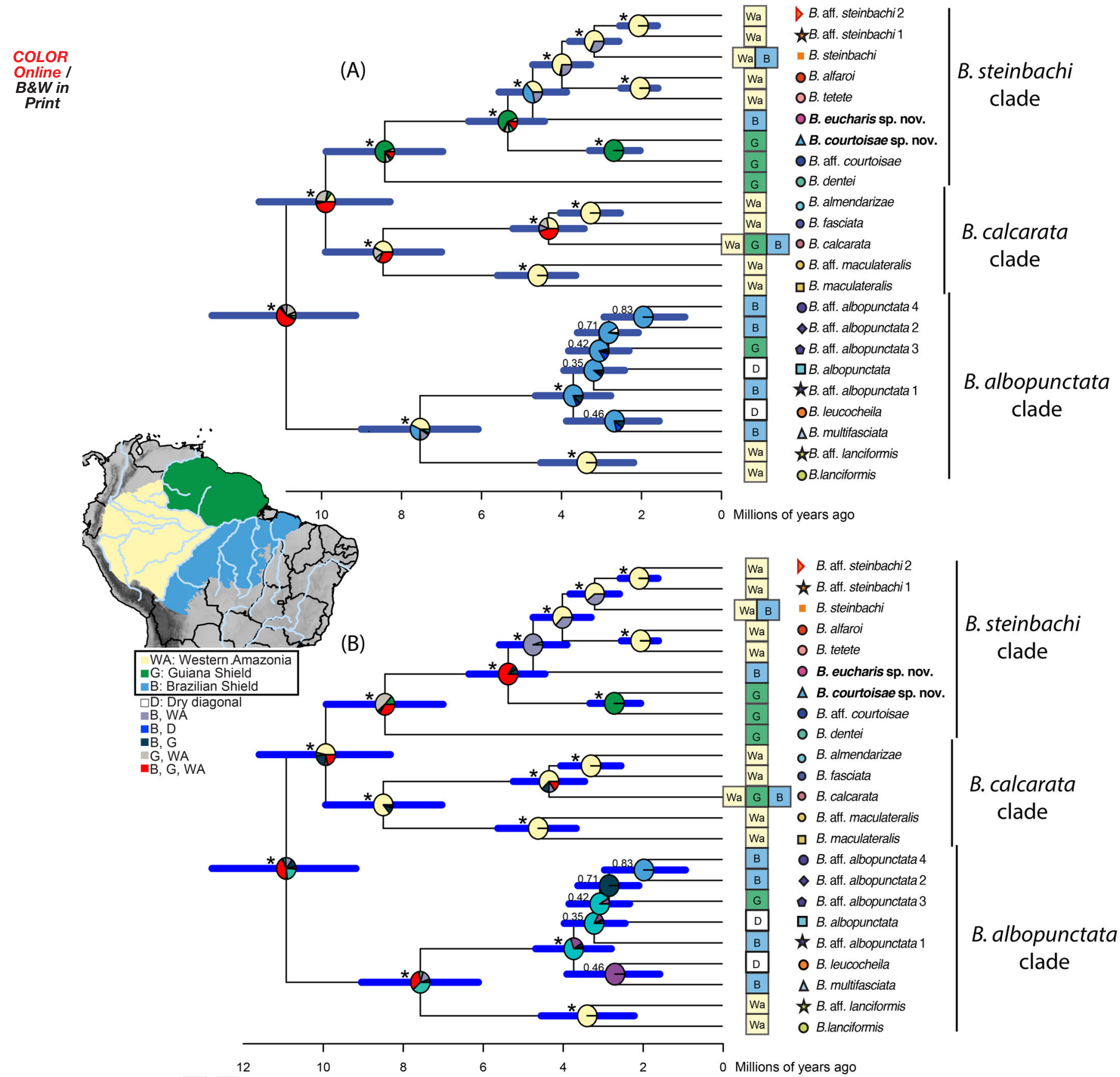

Fig. 8. Ancestral area reconstruction for the Boana albopunctata species group (B. heilprini and B. raniceps excluded) using BioGeoBears assuming (A) a DEC + J model and (B) a DEC model (Appendix 5): most likely biogeographic scenarios plotted on the chronogram obtained with BEAST 2.5, (Numbers on branches are posterior clade probabilities, those ? 0.95 are indicated with an asterisk. Node bars indicate the $95 \%$ highest posterior distributions of node dates. Squares on the tips of the trees indicate the geographic distribution of extant species sampled in the phylogeny. Pie charts on nodes show the most likely reconstructions of ancestral areas, the size of each slice proportional to the maximum likelihood. Colours corresponding to the different geographic distributions are depicted on the left.

with B. lanciformis occurring only in western Amazonia and the rest of the species of the clade occurring in the Cerrado and eastern Amazonia. However, this east-west divergence seems more recent in that group ( $7.5 \mathrm{Ma})$ than the B. calcarata vs. B. steinbachi divergence (9.9 Ma).

\section{Discussion}

\section{Species richness and distribution}

With 25 putative species and two taxa (B. caiapo and $B$. paranaiba) that could not be included in this study, the 
species richness of the B. albopunctata group may actually reach 27 species, i.e., $70 \%$ higher than currently recognized (16 valid species). Within the Amazonian clade, the actual number of species may be $44 \%$ higher than currently recognized (14 OTU for 10 described/ valid species including the two species described herein). We could not gather sufficient phenotypic data for the OTU identified as $B$. aff. maculateralis, but we are confident that such data will contribute to its taxonomic resolution. Moreover, our genetic sampling remains limited, specifically in Colombia, Venezuela, and south-eastern Amazonia, and more species in the group probably remain undocumented.

The discovery of yet undescribed species in Amazonia is not surprising, since new species descriptions of squamates and anurans keep accumulating at a fast pace (e.g. Carvalho et al., 2020; Kok et al., 2018). In fact, almost all systematic investigation of broadly distributed groups in Amazonia led to the understanding that they actually represent species complexes, often hiding narrowly distributed and remotely diverging species within Amazonia (e.g., Fouquet et al., 2014; Vacher et al., 2020). This recurrent pattern is also illustrated herein in the $B$. albopunctata species group notably by B. fasciata, a taxon that was used to design populations throughout Amazonia until the conclusions of Caminer and Ron (2014). The extent of the actual diversity of anurans in Amazonia remains so speculative that it could be three to four times higher than the current $\sim 600$ species occurring in that region according to the IUCN (Vacher et al., 2020).

Relationships and distribution of the species we found within the Amazonian clade strikingly mirror those found in other groups of anurans, notably $B$. semilineata group (Caminer \& Ron, 2020; Fouquet et al., 2016; Peloso et al., 2018); Osteocephalus (Jungfer et al., 2013); Dendropsophus minutus (Gehara et al., 2014); Allobates (Réjaud et al., 2020); Amazophrynella (Rojas et al., 2018); Adenomera (Fouquet et al., 2014) and, more broadly, matches a pattern of allopatry throughout Amazonia in which communities are spatially structured forming distinct bioregions (Vacher et al., 2020). However, the history of Pan-Amazonian diversification is relatively recent in the case of the Amazonian clade of Boana studied herein compared with other taxa, such as Allobates (Réjaud et al., 2020) or Amazophrynella (Rojas et al., 2018). A combination of historical and contemporary climatic heterogeneity as well as speciesspecific dispersal ability and niche breadth (Sheu et al., 2020) is probably responsible for these common and distinct spatio-temporal patterns across taxa. Our timescaled phylogeny and biogeographic analyses provide some insights into the historical processes responsible for the diversification of the B. albopunctata species group in Amazonia.

\section{Biogeography}

With nine OTUs the species richness in western Amazonia is confirmed to be higher than in the Guiana Shield (4 OTUs) and the Brazilian Shield (3 OTUs), suggesting that the climatic conditions and historical geomorphological dynamism in this region, notably hydrological changes, may have played a major role in $B$. gr. albopunctata diversification.

The initial diversification within the Amazonian clade between the $B$. calcarata clade in the west and the $B$. steinbachi in the east of Amazonia dates back to about $10 \mathrm{Ma}$. This estimate is relatively younger than those of Funk et al. (2012) and Duellman et al. (2016) partly because the divergences estimated by Feng et al. (2017), which were used as calibrations herein, are overall more recent than the nodes of those previous studies that were based on a lower amount of genomic data. Other east/ west divergences, putatively simultaneous to the one found herein within the Amazonian clade of the B. albopunctata group, are documented in the Adenomera heyeri clade (Carvalho et al., 2020; Fouquet et al., 2014), in two instances within the Allobates trilineatus clade (Réjaud et al., 2020), in Ameerega (Guillory et al., 2020), and probably in many other lineages for which sampling and dating are still missing. This $10 \mathrm{Myr}$ old node coincides with the end of the Pebas system and the transition from a western watershed drained to the north to a PanAmazonian system drained to the east (Hoorn et al., 2017). Available data indicate that the rise of the Vaupes Arch around $10 \mathrm{Ma}$ completely separated the Western Amazon and Llanos basins (Hoorn et al., 2010; Jaramillo et al., 2017). We assume that this new configuration may have permitted the dispersal between the Guiana Shield and Western Amazonia and could be responsible for this 10 Myr old divergence in the Boana of the Amazonian clade and the other mentioned groups.

Subsequently, both groups have apparently diversified in situ, i.e., within Western Amazonia and within the Guiana Shield until some $5 \mathrm{Ma}$. This date coincides with the divergence between $B$. courtoisae sp. nov. and the other species of the B. steinbachi clade and suggests a dispersal from the Guiana to the Brazilian Shield across the transcontinental configuration of the Amazon River, which contradicts our expectation that such divergence would precede this configuration $(9 \mathrm{Ma}$; Hoorn et al., 2017). Temporally concordant north/south divergences are documented within Allobates tapajos and between A. bacurau and A. sumtuosus (Réjaud et al., 2020), in Chiasmocleis (de Sá et al., 2019) and most likely other 
lineages of terrestrial vertebrates for which the histories of diversification remain undocumented. The processes that may have fostered multiple trans-Amazon dispersals around $5 \mathrm{Ma}$ remain highly speculative. Considerable uncertainty remains about the timing and amplitude of historical topographic, hydrological, and vegetational changes in Amazonia (Albert et al., 2018a; Bicudo, Sacek, de Almeida, Bates, \& Ribas 2019; Campbell, Frailey, \& Romero-Pittman, 2006; Hoorn et al., 2017; Latrubesse et al., 2010). The sediment discharge in the Amazon fan was relatively modest until $5 \mathrm{Ma}$ and vastly increased in the Pliocene-Pleistocene (Albert et al., 2018a ; Hoorn et al., 2017). The lower course of the Amazon River may have become an impassable barrier for these taxa only from the Miocene-Pliocene boundary onward. Moreover, this period also coincides with vegetational and climatic changes, notably the expansion of grasslands not only in the Andes and the Cerrado but also within Amazonia (Kirschner \& Hoorn, 2019).

Subsequently, i.e., the last $5 \mathrm{My}$, both lineages diversified extensively in Western Amazonia, notably along the foothills of the Andes. This diversification has probably been fostered by the combination of increasing availability of suitable terra-firme habitat due to the retreat of the lacustrine ecosystem and dynamic river capture (Albert et al., 2018a). The ancestors of the B. calcarata clade have presumably diversified in the western Acre system, i.e., between the Andes and the Amazon rainforest in the east (Latrubesse et al., 2010). Only recently, dispersal towards the east seems to have occurred, notably in B. calcarata. This last species displays the largest range in the clade, which may be explained by the large diversity of rivers used by that species and the fact that large rivers do not represent efficient barriers for its dispersal.

The diversification of the $B$. albopunctata clade has taken place both in Amazonia and in the Cerrado and appears overall more recent than within the Amazonian clade. These lineages probably originated from transitional ecosystems between the Dry Diagonal and Amazonia. This diversification may be partly related to changes in climate and probable forest retreat in the eastern part of Amazonia during the Late Pliocene and Pleistocene (Cheng et al., 2013; Ledru et al., 2000; Pennington et al., 2000; Van der Hammen \& Hooghiemstra, 2000).

\section{Acknowledgements}

This study benefited from an 'Investissement d'Avenir' grant managed by the Agence Nationale de la Recherche (CEBA, ref. ANR-10-LABX-25-01; TULIP, ref. ANR-10-LABX-0041; ANAEE-France: ANR-11-
INBS-0001). AF and FPW acknowledge the French/ Brazilian GUYAMAZON program action (IRD, CNRS, CTG, CIRAD and Brazilian Fundação de Amparo à Pesquisa do Estado do Amazonas-FAPEAM10.13039/ 501100004916 062.00962/2018). MTR thanks Conselho Nacional de Desenvolvimento Científico e Tecnológico (CNPq) 10.13039/501100003593, Fundação de Amparo à Pesquisa do Estado de São Paulo [FAPESP10.13039/ 501100001807 grant numbers: 2003/10335-8, 2011/ 50146-6], and NSF-FAPESP Dimensions of Biodiversity Program [grant numbers: BIOTA 2013/50297-0, NSFDEB 1343578] and NASA10.13039/100000104. SRR acknowledges a grant from SENESCYT (Arca de Noé Initiative). FPW thanks CNPq (Productivity Fellowship), FAPEAM, Coordenação de Aperfeiçoamento de Pessoal de Nível Superior-CAPES (Visiting Professor Fellowship), and the L'Oréal-UNESCO For Women In Science Program. TH thanks CNPq (Productivity Fellowship) and CNPq/SISBIOTA [563348/2010-0]. Financial support was received through a research grant from the National Council for Scientific and Technological Development (CNPq \#446935/2014-0). TRC is a recipient of a postdoctoral fellowship from FAPESP (\#2017/08489-0), PM is a recipient of a Master's fellowship from Coordenação de Aperfeiçoamento de Pessoal de Nível Superior (CAPES \#88887.201356/2018-00), AAG receives financial support and grants from CNPq (446935/2014-0, 300903/ 2015-4, and 305169/2019-0). We thank the assistance of A.G. Lopes, B.F.V. Teixeira, and D.L. Bang as field companions. We are grateful to C.F.B. Haddad, M.L. Lyra, and Centro de Estudos de Insetos Sociais (CEIS) for providing financial and logistic support and training in DNA sequencing, partly funded by a research grant from FAPESP (\#2013/50741-7; CFBH). The Macaulay Library (ML) at the Cornell Lab of Ornithology, Fonoteca Neotropical Jacques Vielliard (FNJV) enabled access to sound files. The Cornell Lab of Ornithology provided a free license of Raven Pro Software. We also warmly thank members of MTR lab and Arcadis-Logos for help in fieldwork, as well as J. Lima, M. Blanc, J.P. Vacher, E. Courtois, B. Villette, M. Dewynter, Q. Martinez, R. Jairam, and P. Ouboter for their contribution with material used in this work.

\section{Supplemental data}

Supplemental data for this article can be accessed here: https://doi.org/10.1080/14772000.2021.1873869. 


\section{ORCID}

Antoine Fouquet (ID http://orcid.org/0000-00034060-0281

Pedro Marinho (D) http://orcid.org/0000-0001-6432-5312 Thiago R. Carvalho (D) http://orcid.org/0000-00030910-2583

Marcel A. Caminer (D) http://orcid.org/0000-00025827-7462

Miguel T. Rodrigues (D) http://orcid.org/0000-00033958-9919

Ariovaldo A. Giaretta (D) http://orcid.org/0000-00017054-129X

Santiago Ron (D) http://orcid.org/0000-0001-6300-9350

\section{References}

Acosta-Galvis, A. R., Lasso, C. A., \& Morales-Betancourt, M. A. (2018). First record of Boana maculateralis (Caminer $\&$ Ron, 2014) and Boana tetete (Caminer \& Ron, 2014)(Anura, Hylidae) in Colombia. Check List, 14(3), 549-554. https://doi.org/10.15560/14.3.549

Albert, J. S., Val, P., \& Hoorn, C. (2018a). The changing course of the Amazon River in the Neogene: center stage for Neotropical diversification. Neotropical Ichthyology, 16(3), e180033. https://doi.org/10.1590/1982-022420180033

Albert, J. S., Craig, J. M., Tagliacollo, V. A., \& Petry, P. (2018b). Upland and lowland fishes: A test of the River Capture Hypothesis. In C. M. Hoorn, A. Perrigo, \& A. Antonelli (Eds.), Mountains, Climate and Biodiversity. (pp. 273-294). Wiley.

Antonelli, A., Ariza, M., Albert, J., Andermann, T., Azevedo, J., Bacon, C., Faurby, S., Guedes, T., Hoorn, C., Lohmann, L. G., Matos-Maraví, P., Ritter, C. D., Sanmartín, I., Silvestro, D., Tejedor, M., Ter Steege, H., Tuomisto, H., Werneck, F. P., Zizka, A., \& Edwards, S. V. (2018). Conceptual and empirical advances in Neotropical biodiversity research. PeerJ., 6, e5644 https://doi.org/10. $7717 /$ peerj. 5644

Ávila, R. W., \& Kawashita-Ribeiro, R. A. (2011). Herpetofauna of São João da Barra Hydroelectric Plant, state of Mato Grosso. Check List, 7(6), 750-755. https://doi. org $/ 10.15560 / 11014$

Ávila-Pires, T. C. S. D., Hoogmoed, M. S., \& Rocha, W. A. D. (2010). Notes on the Vertebrates of northern Pará, Brazil: a forgotten part of the Guianan Region, I. Herpetofauna. Boletim Do Museu Paraense Emílio Goeldi, 5(1), 13-122.

Bicudo, T. C., Sacek, V., de Almeida, R. P., Bates, J. M., \& Ribas, C. C. (2019). Andean tectonics and Mantle Dynamics as a Pervasive Influence on Amazonian ecosystem. Scientific Reports, 9(1), 1-11. https://doi.org/10. 1038/s41598-019-53465-y

Bokermann, W. C. A. (1967). Nova espéce de Hyla do Amapá (Amphibia, Hylidae). Revista Brasileira de Biologia, 27, 109-112.

Bouckaert, R., Heled, J., Kühnert, D., Vaughan, T., Wu, C. H., Xie, D., Suchard, M. A., Rambaut, A., \& Drummond, A. J. (2014). BEAST 2: A Software Platform for Bayesian Evolutionary Analysis. PLoS Comput Biol,
10(4), e1003537 https://doi.org/10.1371/journal.pcbi. 1003537

Boulenger, G. A. (1905). Descriptions of new tailless batrachians in the collection of the British Museum. Annals and Magazine of Natural History, 16(92), 180-184. https:// doi.org/10.1080/03745480509443666

Caminer, M. A., \& Ron, S. R. (2014). Systematics of treefrogs of the Hypsiboas calcaratus and Hypsiboas fasciatus species complex (Anura, Hylidae) with the description of four new species. Zookeys, 370, 1.

Caminer, M. A., \& Ron, S. R. (2020). Molecular phylogeny and morphology of Ecuadorian frogs of the genus Boana (Anura: Hylidae) with the description of two new species. Zoological Journal of the Linnean Society, 190(1), 149-180. https://doi.org/10.1093/zoolinnean/zlaa002

Campbell, K. E., Jr, Frailey, C. D., \& Romero-Pittman, L. (2006). The Pan-Amazonian Ucayali Peneplain, late Neogene sedimentation in Amazonia, and the birth of the modern Amazon River system. Palaeogeography, Palaeoclimatology, Palaeoecology, 239(1-2), 166-219. https://doi.org/10.1016/j.palaeo.2006.01.020

Camurugi, F., Gehara, M., Fonseca, E. M., Zamudio, K. R., Haddad, C. F. B., Colli, G. R., Thomé, M. T. C., Prado, C. P. A., Napoli, M. F., \& Garda, A. A. (2021). Isolation by environment and recurrent gene flow shaped the evolutionary history of a continentally distributed Neotropical treefrog. Journal of Biogeography, in press.

Caramaschi, U., \& de Niemeyer, H. (2003). New species of the Hyla albopunctata group from central Brazil (Amphibia, Anura, Hylidae). Boletim do Museu Nacional. Nova Serie, Zoologia, 504, 1-8.

Carvalho, T. R., Giaretta, A. A., \& Facure, K. G. (2010). A new species of Hypsiboas Wagler (Anura: Hylidae) closely related to $H$. multifasciatus Günther from southeastern Brazil. Zootaxa, 2521, 37-52.

Carvalho, T. R., Bang, D. L., Teixeira, B. F. V., \& Giaretta, A. A. (2017). First record of Boana alfaroi (Caminer \& Ron, 2014) (Anura: Hylidae) in Brazil. Check List, 13, 135-139.

Carvalho, T. R., Moraes, L. C. J. L., Lima, A. P., Fouquet, A., Peloso, P. L. V., Pavan, D., Drummond, L. O., Rodrigues, M. T., Giaretta, A. A., Gordo, M., Neckel-Oliveira, S., \& Haddad, C. F. B. (2020). Systematics and historical biogeography of Neotropical foam-nesting frogs of the Adenomera heyeri clade (Leptodactylidae), with the description of six new Amazonian species. Zoological Journal of the Linnean Society, in press. https://doi.org/10. 1093/zoolinnean/zlaa051

Ceballos, G., Ehrlich, P. R., Barnosky, A. D., García, A., Pringle, R. M., \& Palmer, T. M. (2015). Accelerated modern human-induced species losses: Entering the sixth mass extinction. Science Advances, 1(5), e1400253 https:// doi.org/10.1126/sciadv. 1400253

Cheng, H., Sinha, A., Cruz, F. W., Wang, X., Edwards, R. L., d'Horta, F. M., Ribas, C. C., Vuille, M., Stott, L. D., \& Auler, A. S. (2013). Climate change patterns in Amazonia and biodiversity. Nature Communications, 4(1), 1-6. https:// doi.org/10.1038/ncomms 2415

Cole, C. J., Townsend, C. R., Reynolds, R. P., MacCulloch, R. D., \& Lathrop, A. (2013). Amphibians and reptiles of Guyana, South America: illustrated keys, annotated species accounts, and a biogeographic synopsis. Proceedings of the Biological Society of Washington, 125(4), 317-578. https:// doi.org/10.2988/0006-324X-125.4.317 
Cope, E. D. (1862 Catalogues of the reptiles obtained during the explorations of the Parana, Paraguay, Vermejo and Uruguay Rivers, by Capt. Thos. J. Page, U.S.N.; and of those procured by Lieut. N. Michler, U.S. Top. Eng., Commander of the expedition conducting the survey of the Atrato River [Paper presentation]. Proceedings of the Academy of Natural Sciences of Philadelphia, 14, 346-359.

Cope, E. D. (1871). Eighth contribution to the herpetology of tropical America. Proceedings of the American Philosophical Society, 11, 553-559. "1870".

De la Riva, I. (1990). Lista preliminar comentada de los anfibios de Bolivia con datos sobre su distribución. Bollettino. Museo Regionale di Scienze Naturali. Tori, 8, 261-319.

de Sá, R. O., Tonini, J. F. R., van Huss, H., Long, A., Cuddy, T., Forlani, M. C., Peloso, P. L., Zaher, H., \& Haddad, C. F. (2019). Multiple connections between Amazonia and Atlantic Forest shaped the phylogenetic and morphological diversity of Chiasmocleis Mehely, 1904 (Anura: Microhylidae: Gastrophryninae). Molecular Phylogenetics and Evolution, 130, 198-210. https://doi.org/10.1016/j. ympev.2018.10.021

Dewynter, M., Marty, C., Blanc, M., Gaucher, P., Vidal, N., Frétey, T., de Massary, J. C., Fouquet, A. (2008). Liste des Amphibiens et des Reptiles de Guyane. Available online: http://www.chelidae.com/pdf/dewynter2008.pdf.

Drummond, A. J., Ho, S. Y. W., Phillips, M. J., \& Rambaut, A. (2006). Relaxed phylogenetics and dating with confidence. PLoS Biology, 4(5), e88 https://doi.org/10.1371/ journal.pbio.0040088

Dubois, A. (2017). The nomenclatural status of Hysaplesia, Hylaplesia, Dendrobates and related nomina (Amphibia, Anura), with general comments on zoological nomenclature and its governance, as well as on taxonomic databases and websites. Bionomina, 11(1), 1-48. https://doi.org/10.11646/ bionomina.11.1.1

Duellman, W. E., Marion, A. B., \& Hedges, S. B. (2016). Phylogenetics, classification, and biogeography of the treefrogs (Amphibia: Anura: Arboranae). Zootaxa, 4104(1), 1-109. https://doi.org/10.11646/zootaxa.4104.1.1

Dupin, J., Matzke, N. J., Särkinen, T., Knapp, S., Olmstead, R. G., Bohs, L., \& Smith, S. D. (2017). Bayesian estimation of the global biogeographical history of the Solanaceae. Journal of Biogeography, 44(4), 887-899. https://doi.org/10.1111/jbi.12898

Ezard, T., Fujisawa, T., \& Barraclough, T. (2009). splits: SPecies' LImits by Threshold Statistics. R package version $1.0-11 / \mathrm{r} 29$.

Faivovich, J., Haddad, C. F., Garcia, P. C., Frost, D. R., Campbell, J. A., \& Wheeler, W. C. (2005). Systematic review of the frog family Hylidae, with special reference to Hylinae: phylogenetic analysis and taxonomic revision. Bulletin of the American Museum of Natural History, 294(1), 1-240. https://doi.org/10.1206/00030090(2005)294[0001:SROTFF]2.0.CO;2

Feng, Y. J., Blackburn, D. C., Liang, D., Hillis, D. M., Wake, D. B., Cannatella, D. C., \& Zhang, P. (2017). Phylogenomics reveals rapid, simultaneous diversification of three major clades of Gondwanan frogs at the Cretaceous-Paleogene boundary. Proceedings of the National Academy of Sciences of the United States of America, 114(29), E5864-E5870. https://doi.org/10.1073/ pnas. 1704632114
Ficetola, G. F., Rondinini, C., Bonardi, A., Katariya, V., Padoa-Schioppa, E., \& Angulo, A. (2014). An evaluation of the robustness of global amphibian range maps. Journal of Biogeography, 41(2), 211-221. https://doi.org/10.1111/jbi. 12206

Fouquet, A., Gilles, A., Vences, M., Marty, C., Blanc, M., \& Gemmell, N. J. (2007). Underestimation of species richness in Neotropical frogs revealed by mtDNA analyses. PLoS One, 2(10), e1109 https://doi.org/10.1371/journal.pone. 0001109

Fouquet, A., Cassini, C. S., Haddad, C. F. B., Pech, N., \& Rodrigues, M. T. (2014). Species delimitation, patterns of diversification and historical biogeography of the Neotropical frog genus Adenomera (Anura, Leptodactylidae). Journal of Biogeography, 41(5), 855-870. https://doi.org/10.1111/jbi.12250

Fouquet, A., Martinez, Q., Zeidler, L., Courtois, E. A., Gaucher, P., Blanc, M., Lima, J. D., Souza, S. M., Rodrigues, M. T., Lima, J. D., Souza, S. M., Rodrigues, M. T., \& Kok, P. J. R. (2016). Cryptic diversity in the Hypsiboas semilineatus species group (Amphibia, Anura) with the description of a new species from the eastern Guiana Shield. Zootaxa, 4084(1), 79-104. https://doi.org/10. 11646/zootaxa.4084.1.3

Fouquet, A., Gilles, A., Vences, M., Marty, C., Blane, M., \& Gemmell, N. J. (2007a). Underestimation of species richness in Neotropical frogs revealed by mtDNA analyses. PLos One, 2(10), e1109 https://doi.org/10.1371/journal. pone. 0001109

Fouquet, A., Loebmann, D., Castroviejo-Fisher, S., Padial, J. M., Orrice, V. G., Lyra, M. L., Roberte, I. J., Kok, P. J., Haddad, C. F., \& Rodrigues, M. T. (2012). From Amazonia to the Atlantic forest: Molecular phylogeny of Phyzelaphryninae frogs reveals unexpected diversity and a striking biogeographic pattern emphasizing conservation challenges. Molecular Phylogeneties and Evolution, 65(2), 547 561. https://doi.org/10.1016/j.ympev.2012.07.012

Fouquet, A., Vidal, N., \& Dewynter, M. (2019). The Amphibians of the Mitaraka massif, French Guiana. Zoosystema, 41(sp1), 359-374. https://doi.org/10.5252/ zoosystema2019v41a19

Frost, D. R. (2019). Amphibian Species of the World: an Online Reference. Version 6.1 (Date of access). Electronic Database accessible at https://amphibiansoftheworld.amnh. org/index.php. American Museum of Natural History, New York, USA.

Funk, W. C., Caminer, M., \& Ron, S. R. (2012). High levels of cryptic species diversity uncovered in Amazonian frogs. Proceedings of the Royal Society B: Biological Sciences, 279(1734), 1806-1814. https://doi.org/10.1098/rspb.2011. 1653

Gaige, H. T. (1929). Three new tree-frogs from Panama and Bolivia. Occasional Papers of the Museum of Zoology, University of Michigan, 207, 1-6.

Gehara, M., Crawford, A. J., Orrico, V. G. D., Rodríguez, A., Lötters, S., Fouquet, A., Barrientos, L. S., Brusquetti, F., De la Riva, I., Ernst, R., Urrutia, G. G., Glaw, F., Guayasamin, J. M., Hölting, M., Jansen, M., Kok, P. J. R., Kwet, A., Lingnau, R., Lyra, M., ... Köhler, J. (2014). High levels of diversity uncovered in a widespread nominal taxon: continental phylogeography of the Neotropical tree frog Dendropsophus minutus. PloS One, 9(9), e103958 https://doi.org/10.1371/journal.pone.0103958 
Godinho, M. B. d C., \& Da Silva, F. R. (2018). The influence of riverine barriers, climate, and topography on the biogeographic regionalization of Amazonian anurans. Scientific Reports, 8(1), 1-11. https://doi.org/10.1038/ s41598-018-21879-9

Guerra, V., Jardim, L., Llusia, D., Márquez, R., \& Bastos, R. P. (2020). Knowledge status and trends in description of amphibian species in Brazil. Ecological Indicators, 118, 106754. https://doi.org/10.1016/j.ecolind.2020.106754

Guillory, W. X., French, C. M., Twomey, E. M., Chávez, G., Prates, I., von May, R., De la Riva, I., Lötters, S., Reichle, S., Serrano-Rojas, S. J., Whitworth, A., \& Brown, J. L. (2020). Phylogenetic relationships and systematics of the Amazonian poison frog genus Ameerega using ultraconserved genomic elements. Mol Phylogenet Evol, 142, 106638 https://doi.org/10.1016/j.ympev.2019.106638

Günther, A. C. L. G. (1858). Neue Batrachier in der Sammlung des britischen Museums. Archiv Für Naturgeschichte., 24, 319-328. https://doi.org/10.5962/bhl. part.5288

Günther, A. C. L. G. (1859). "1858". Catalogue of the Batrachia Salientia in the Collection of the British Museum. Taylor and Francis.

Haffer, J. (1969). Speciation in Amazonian forest birds. Science (New York, N.Y.).), 165(3889), 131-137. https://doi. org/10.1126/science.165.3889.131

Heyer, W. R., Rand, A. S., Cruz, C. A. G., Peixoto, O. L., \& Nelson, C. E. (1990). Frogs of Boracéia. Arquivos de Zoologia, 31, 231-410.

Hoorn, C., Wesselingh, F. P., ter Steege, H., Bermudez, M. A., Mora, A., Sevink, J., Sanmartin, I., SanchezMeseguer, A., Anderson, C. L., Figueiredo, J. P., Jaramillo, C., Riff, D., Negri, F. R., Hooghiemstra, H., Lundberg, J., Stadler, T., Särkinen, T., \& Antonelli, A. (2010). Amazonia through time: Andean uplift, climate change, landscape evolution, and biodiversity. Science (New York, N.Y.).), 330(6006), 927-931. https://doi.org/10.1126/science. 1194585

Hoorn, C., Bogotá-A, G. R., Romero-Baez, M., Lammertsma, E. I., Flantua, S. G., Dantas, E. L., Dino, R., do Carmo, D. A., \& Chemale, F. Jr., (2017). The Amazon at sea: Onset and stages of the Amazon River from a marine record, with special reference to Neogene plant turnover in the drainage basin. Global and Planetary Change, 153, 51-65. https://doi.org/10.1016/j.gloplacha.2017.02.005

Jansen, M., Bloch, R., Schulze, A., \& Pfenninger, M. (2011). Integrative inventory of Bolivia's lowland anurans reveals hidden diversity. Zoologica Scripta, 40(6), 567-583. https:// doi.org/10.1111/j.1463-6409.2011.00498.x

Jaramillo, C., Romero, I., D'Apolito, C., Bayona, G., Duarte, E., Louwye, S., Escobar, J., Luque, J., Carrillo-Briceño, J. D., Zapata, V., Mora, A., Schouten, S., Zavada, M., Harrington, G., Ortiz, J., \& Wesselingh, F. P. (2017). Miocene flooding events of western Amazonia. Science Advances, 3(5), e1601693 https://doi.org/10.1126/sciadv. 1601693

Jenkins, C. N., Pimm, S. L., \& Joppa, L. N. (2013). Global patterns of terrestrial vertebrate diversity and conservation. Proceedings of the National Academy of Sciences, 110(28), E2602-E2610. https://doi.org/10.1073/pnas.1302251110

Jungfer, K.-H., Faivovich, J., Padial, J. M., Castroviejo-Fisher, S., Lyra, M. M., V. M. Berneck, B., Iglesias, P. P., Kok, P. J. R., MacCulloch, R. D., Rodrigues, M. T., Verdade, V. K., Torres Gastello, C. P., Chaparro, J. C., Valdujo,
P. H., Reichle, S., Moravec, J., Gvoždík, V., GagliardiUrrutia, G., Ernst, R., ... F. B. Haddad, C. (2013). Systematics of spiny-backed treefrogs (Hylidae: Osteocephalus): an Amazonian puzzle. Zoologica Scripta, 42(4), 351-380. https://doi.org/10.1111/zsc.12015

Kapli, P., Lutteropp, S., Zhang, J., Kobert, K., Pavlidis, P., Stamatakis, A., \& Flouri, T. (2017). Multi-rate Poisson tree processes for single-locus species delimitation under maximum likelihood and Markov chain Monte Carlo. Bioinformatics (Oxford, England)), 33(11), 1630-1638. https://doi.org/10.1093/bioinformatics/btx025

Katoh, K., Rozewicki, J., \& Yamada, K. D. (2019). MAFFT online service: multiple sequence alignment, interactive sequence choice and visualization. Briefings in Bioinformatics, 20(4), 1160-1166. https://doi.org/10.1093/ $\mathrm{bib} / \mathrm{bbx} 108$

Kirschner, J. A., \& Hoorn, C. (2019). The onset of grasses in the Amazon drainage basin, evidence from the fossil record. Frontiers of Biogeography, 12, e44827.

Klaus, K. V., \& Matrke, N. J. (2020). Statistical Comparison of Trait-dependent Biogeographical Models indicates that Podocarpaceae Dispersal is influenced by both Seed Cone Traits and Geographieal Distance. Systematic Biology, 69(1), 61 75. https://doi.org/10.1093/sysbio/syz034

Köhler, J., Jansen, M., Rodríguez, A., Kok, P. J. R., Toledo, L. F., Emmrich, M., Glaw, F., Haddad, C. F. B., Rödel, M.O., \& Vences, M. (2017). The use of bioacoustics in anuran taxonomy: theory, terminology, methods and recommendations for best practice. Zootaxa, 4251(1), 1-124. https://doi.org/10.11646/zootaxa.4251.1.1

Kok, P. J., Bittenbinder, M. A., van den Berg, J. K., MarquesSouza, S., Sales Nunes, P. M., Laking, A. E., Teixeira, M., Jr., Fouquet, A., Means, D. B., MacCulloch, R. D., \& Rodrigues, M. T. (2018). Integrative taxonomy of the gymnophthalmid lizard Neusticurus rudis Boulenger, 1900 identifies a new species in the eastern Pantepui region, north-eastern South America. Journal of Natural History, 52(13-16), 1029-1066. https://doi.org/10.1080/00222933. 2018.1439541

Lanfear, R., Frandsen, P. B., Wright, A. M., Senfeld, T., \& Calcott, B. (2016). PartitionFinder 2: New methods for selecting partitioned models of evolution for molecular and morphological phylogenetic analyses. Molecular Biology and Evolution, 34(3), 772-773.

Latrubesse, E. M., Cozzuol, M., da Silva-Caminha, S. A., Rigsby, C. A., Absy, M. L., \& Jaramillo, C. (2010). The Late Miocene paleogeography of the Amazon Basin and the evolution of the Amazon River system. Earth-Science Reviews, 99(3-4), 99-124. https://doi.org/10.1016/j. earscirev.2010.02.005

Ledru, M.-P., Blanc, P., Charles-Dominique, P., Fournier, M., Martin, L., Riera, B., \& Tardy, C. (2000). Reconstitution de l'écosystème forestier guyanais au cours de l'Holocène supérieur: apport de la palynologie. In M. Servan, \& S Servant Vildar (Eds.), Dynamique à long terme des écosystèmes forestiers intertropicaux. (pp. 199-204). UNESCO.

Leite, R. N., \& Rogers, D. S. (2013). Revisiting Amazonian phylogeography: Insights into diversification hypotheses and novel perspectives. Organisms Diversity \& Evolution, 13(4), 639-664. https://doi.org/10.1007/s13127-013-0140-8

Lescure, J., \& Marty, C. (2000). Atlas des amphibiens de Guyane. Collection patrimoines naturels. 
Ligges, U., Krey, S., Mersmann, O., Schnackenberg, S. (2014). TuneR: Analysis of music. Accessed May 8, 2017. Available at: http://r-forge.r-project.org/projects/tuner.

Lima, A. P., Keller, C., \& Rebelo, G. H. (2017). Estudos ambientais no Rio Madeira, trecho Cachoeira de Santo Antônio-Abunã (Rondônia): Herpetofauna. Relatório elaborado para Furnas Centrais Elétricas SA como parte do Estudo de Viabilidade dos AHEs Santo Antônio e Jirau, para o Aproveitamento Hidrelétrico do Rio Madeira. INPA, Manaus.

Lovejoy, T. E., \& Nobre, C. (2019). Amazon tipping point: Last chance for action. Science Advances, 5(12), eaba2949 https://doi.org/10.1126/sciadv.aba2949

Marinho, P., Costa-Campos, C. E., Pezzuti, T. L., Magalhães, R. F., Souza, M. R. D., Haddad, C. F. B., Giaretta, A. A., \& De Carvalho, T. R. (2020). The Amapá treefrog Boana dentei (Bokermann, 1967): diagnosis and redescription. Journal of Natural History, 54(15-16), 971-990. https://doi. org/10.1080/00222933.2020.1777336

Matzke, N. J. (2013). BioGeoBEARS: biogeography with Bayesian (and likelihood) evolutionary analysis in R scripts. $R$ Package, Version 0.2, 1, 2013.

McCormack, J. E., Heled, J., Delaney, K. S., Peterson, A. T., \& Knowles, L. L. (2011). Calibrating divergence times on species trees versus gene trees: implications for speciation history of Aphelocoma jays. Evolution; International Journal of Organic Evolution, 65(1), 184-202. https://doi. org/10.1111/j.1558-5646.2010.01097.x

Meyer, C., Kreft, H., Guralnick, R., \& Jetz, W. (2015). Global priorities for an effective information basis of biodiversity distributions. Nature Communications, 6(1), 1-8. https://doi. org/10.1038/ncomms9221

Medina-Rangel, G. F., Méndez-Galeano, M. A., \& CalderónEspinosa, M. L. (2019). Herpetofauna of San José del Guaviare, Guaviare, Colombia. Biota Colombiana, 20(1), 75-90. https://doi.org/10.21068/c2019.v20n01a05

Medina-Rangel, G. F., Thompson, M. E., Ruiz-Valderrama, D. H., Fajardo Muñoz, W., Lombana Lugo, J., LondoñoGuarnizo, C. A., Moquena Carbajal, C., Ríos Rosero, H. D., Sánchez Pamo, J. E., \& Sánchez, E. (2019). Anfibios y reptiles. In N. Pitman, A. Salazar Molano, F. Samper Samper, C. Vriesendorp, A. Vásquez Cerón, Á. del Campo, T. L. Miller, E. A. Matapi Yucuna, M. E. Thompson, L. de Souza, D. Alvira Reyes, D. F. Stotz, N. Kotlinski, T. Wachter, E. Woodward \& R. Botero García. (Eds.), Colombia: Bajo Caguán-Caquetá. Rapid Biological and Social Inventories report. 30 (pp. 111-454). Field Museum.

Meza-Joya, F. L., Ramos-Pallares, E., \& Hernández-Jaimes, C. (2019). Hidden diversity in frogs within Boana calcarata-fasciata and Boana geographica species complexes from Colombia. Herpetology Notes, 12, 391-400.

Monaghan, M. T., Wild, R., Elliot, M., Fujisawa, T., Balke, M., Inward, D. J. G., Lees, D. C., Ranaivosolo, R., Eggleton, P., Barraclough, T. G., \& Vogler, A. P. (2009). Accelerated species inventory on Madagascar using coalescent-based models of species delineation. Systematic Biology, 58(3), 298-311. https://doi.org/10.1093/sysbio/ syp027

Müller, L. (1924). Neue Batrachier aus Ost-Brasilien. Senckenbergiana Biologica, 6, 169-177.

Myers, N., Mittermeier, R. A., Mittermeier, C. G., da Fonseca, G. A., \& Kent, J. (2000). Biodiversity hotspots for conservation priorities. Nature, 403(6772), 853-858.
Near, T. J., Eytan, R. I., Dornburg, A., Kuhn, K. L., Moore, J. A., Davis, M. P., Wainwright, P. C., Friedman, M., \& Smith, W. L. (2012). Resolution of ray-finned fish phylogeny and timing of diversification. Proceedings of the National Academy of Sciences, 109(34), 13698-13703. https://doi.org/10.1073/pnas.1206625109

Noble, G. K. (1923). Six new batrachians from the Dominican Republic. American Museum Novitates, 61, 1-6.

Oliveira, U., Vasconcelos, M. F., \& Santos, A. J. (2017). Biogeography of Amazon birds: rivers limit species composition, but not areas of endemism. Scientific Reports, 7(1), 1-11. https://doi.org/10.1038/s41598-017-03098-w

Ouboter, P. E., \& Jairam, R. (2012). Amphibians of Suriname. Brill. 376. pp.

Pansonato, A., Ávila, R. W., Kawashita-Ribeiro, R. A., \& Morais, D. H. (2011). Advertisement call and new distribution records of Hypsiboas leucocheilus (Anura: Hylidae). Salamandra, 47, 55-58.

Parker, H. W. ( (1927). ). The brevicipitid frogs allied to the genus Hypopachus. Occasional Papers of the Museum of Zoology, University of Michigan, 187, 1-6.

Pennington, R. T., Prado, D. E., \& Pendry, C. A. (2000). Neotropical seasonally dry forests and Quaternary vegetation changes. Journal of Biogeography, 27(2), 261-273. https://doi.org/10.1046/j.1365-2699.2000.00397.x

Peloso, P. L., De Oliveira, R. M., Sturaro, M. J., Rodrigues, M. T., Lima-Filho, G. R., Bitar, Y. O., Wheeler, W. C., \& Aleixo, A. (2018). Phylogeny of map tree frogs, Boana semilineata species Group, with a new amazonian species (Anura: Hylidae). South American Journal of Herpetology, 13(2), 150-169. https://doi.org/10.2994/SAJH-D-17-00037.1

Pinheiro, P. D. P., Cintra, C. E. D., Valdujo, P. H., da Silva, H. L. R., Martins, I. A., da Silva, N. J., Jr., \& Garcia, P. C. A. (2018). A new species of the Boana albopunctata group (Anura: Hylidae) from the Cerrado of Brazil. South American Journal of Herpetology, 13(2), 170-182. https:// doi.org/10.2994/SAJH-D-17-00040.1

Pirani, R. M., Werneck, F. P., Thomaz, A. T., Kenney, M. L., Sturaro, M. J., Ávila-Pires, T. C. S., Peloso, P. L. V., Rodrigues, M. T., \& Knowles, L. L. (2019). Testing main Amazonian rivers as barriers across time and space within widespread taxa. Journal of Biogeography, 46(11), 2444-2456. https://doi.org/10.1111/jbi.13676

Pons, J., Barraclough, T. G., Gomez-Zurita, J., Cardoso, A., Duran, D. P., Hazell, S., Kamoun, S., Sumlin, W. D., \& Vogler, A. P. (2006). Sequence-based species delimitation for the DNA taxonomy of undescribed insects. Systematic Biology, 55(4), 595-609. https://doi.org/10.1080/ 10635150600852011

Prado, C. P., Haddad, C. F. B., \& Zamudio, K. R. (2012). Cryptic lineages and Pleistocene population expansion in a Brazilian Cerrado frog. Molecular Ecology, 21(4), 921-941. https://doi.org/10.1111/j.1365-294X.2011.05409.x

Puillandre, N., Lambert, A., Brouillet, S., \& Achaz, G. (2012). ABGD, Automatic Barcode Gap Discovery for primary species delimitation. Molecular Ecology, 21(8), 1864-1877. https://doi.org/10.1111/j.1365-294X.2011.05239.x

R Core Team. (2018). R: a language and environment for statistical computing. $\mathrm{R}$ Foundation for Statistical Computing. Version 3.5.0. Accessed July 29, 2020. Available at: https://www.R-project.org/.

Ree, R. H., \& Sanmartín, I. (2018). Conceptual and statistical problems with the $\mathrm{DEC}+\mathrm{J}$ model of founder-event speciation and its comparison with DEC via model 
selection. Journal of Biogeography, 45(4), 741-749. https:// doi.org/10.1111/jbi.13173

Réjaud, A., Rodrigues, M. T., Crawford, A. J., CastroviejoFisher, S., Jaramillo, A. F., Chaparro, J. C., Glaw, F., Gagliardi-Urrutia, G., Moravec, J., De la Riva, I. J., Perez, P., Lima, A. P., Werneck, F. P., Hrbek, T., Ron, S. R., Ernst, R., Kok, P. J. R., Driskell, A., Chave, J., \& Fouquet, A. (2020). Historical biogeography identifies a possible role of the Pebas system in the diversification of the Amazonian rocket frogs (Aromobatidae: Allobates). Journal of Biogeography, 47(11), 2472-2482. https://doi.org/10.1111/ jbi.13937

Ribas, C. C., Aleixo, A., Nogueira, A. C. R., Miyaki, C. Y., \& Cracraft, J. (2012). A palaeobiogeographic model for biotic diversification within Amazonia over the past three million years. Proceedings. Biological Sciences, 279(1729), 681-689. https://doi.org/10.1098/rspb.2011.1120

Rodrigues, D. J., Noronha, J. C., Vindica, V. F., \& Barbosa, F. R. (2015). Biodiversidade do Parque Estadual do Cristalino. Áttema Editorial.

Rojas-Zamora, R. R., de Carvalho, V. T., Ávila, R. W., de Almeida, A. P., de Oliveira, E. A., Menin, M., \& Gordo, M. (2017). Hypsiboas maculateralis Caminer \& Ron, 2014, new to Brazil. Herpetozoa, 30, 108-114.

Rojas, R. R., Fouquet, A., Ron, S. R., Hernández-Ruz, E. J., Melo-Sampaio, P. R., Chaparro, J. C., Vogt, R. C., de Carvalho, V. T., Pinheiro, L. C., Avila, R. W., Farias, I. P., Gordo, M., \& Hrbek, T. (2018). A Pan-Amazonian species delimitation: high species diversity within the genus Amazophrynella (Anura: Bufonidae). PeerJ., 6, e4941 https://doi.org/10.7717/peerj.4941

Ruokolainen, K., Moulatlet, G. M., Zuquim, G., Hoorn, C., \& Tuomisto, H. (2018). River network rearrangements in Amazonia shake biogeography and civil security. Preprints, 2018090168.

Ruthven, A. G. (1927). Description of an apparently new species of Apostolepis from Bolivia. Occasional Papers of the Museum of Zoology, University of Michigan, 188, 1-2.

Savage, J. M., \& Heyer, W. R. (1997). Digital webbing formulae for anurans: a refinement. Herpetological Review, 28,131

Sheu, Y., Zurano, J. P., Ribeiro-Junior, M. A., Avila-Pires, T. C. S., Rodrigue, M. Ts., Colli, G. R., \& Werneck, F. P. (2020). The combined role of dispersal and niche evolution in the diversification of Neotropical lizards. Ecology and Evolution, 10(5), 2608-2625. https://doi.org/10.1002/ece3. 6091

Silva, L. A., Magalhães, F. M., Themassen, H., Leite, F. S. F.,

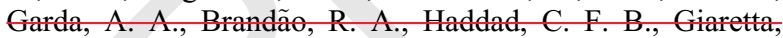
A. A., \& Carvalhe, T. R. (2020). Unraveling the species diversity and relationships in the Leptodactylus mystaceus eomplex (Anura: Leptodactylidae), with the deseription of three new Brazilian species. Zootaxa, 4779, 151189.

Spix, J. B. v. (1824). Animalia nova sive Species novae Testudinum et Ranarum quas in itinere per Brasiliam annis MDCCCXVII-MDCCCXX jussu et auspiciis Maximiliani Josephi I. Bavariae Regis. F. S. Hübschmann.

Stamatakis, A. (2014). RAxML version 8: a tool for phylogenetic analysis and post-analysis of large phylogenies. Bioinformatics (Oxford, England)), 30(9), 1312-1313. https://doi.org/10.1093/bioinformatics/btu033

Sturare, M. J., Costa, J. C. L., Maciel, A. O., Lima-Filho, G. R., Rojas-Runjaic, F. J., Mejia, D. P., Ron, S. R., \& Pelose, P. L. (2020). Resolving the taxonomic puzzle of Boana cinerascens (Spix, 1824), with resurrection of Hyla granosa gracilis Melin, 1941 (Anura: Hylidae). Zootaxa, 4750(1), 1 30. https://doi.org/10.11646/zootaxa.4750.1.1

Sueur, J., Aubin, T., \& Simonis, C. (2008). Seewave, a free modular tool for sound analysis and synthesis. Bioacoustics, 18(2), 213-226. https://doi.org/10.1080/09524622.2008. 9753600

Troschel, F. H. (1848). Theil 3. Versuch einer Zusammenstellung der Fauna und Flora von BritischGuiana. Schomburgk, R. ed., Reisen in Britisch-Guiana in den Jahren 1840-44. Im Auftrage Sr. Majestät des Königs von Preussen ausgeführt. : 645-661J. J. Weber.

IUCN. (2020). The IUCN Red List of Threatened Species. Version 2020-1. https://www.iucnredlist.org. Downloaded on 19 March 2020.

Vacher, J.-P., Chave, J., Ficetola, F., Sommeria-Klein, G., Tao, S., Thébaud, C., Blanc, M., Camacho, A., Cassimiro, J., Colston, T. J., Dewynter, M., Ernst, R., Gaucher, P., Gome, s J. O., Jairam, R., Kok, P. J. R., Dias Lima, J., Martinez, Q., Marty, C., ... Fouquet, A. (2020). Large scale DNA-based survey of Amazonian frogs suggest a vast underestimation of species richness and endemism. Journal of Biogeography, 47(8), 1781-1791. https://doi.org/10.1111/ jbi. 13847

Van der Hammen, T., \& Hooghiemstra, H. (2000). Neogene and Quaternary history of vegetation, climate, and plant diversity in Amazonia. Quaternary Science Reviews, 19(8), 725-742. https://doi.org/10.1016/S0277-3791(99)00024-4

Vences, M., Thomas, M., Bonett, R. M., \& Vieites, D. R. (2005). Deciphering amphibian diversity through DNA barcoding: chances and challenges. Philosophical Transactions of the Royal Society B: Biological Sciences, 360(1462), 1859-1868. https://doi.org/10.1098/rstb.2005. 1717

Wallace, A. R. (1854). On the monkeys of the Amazon. Annals and Magazine of Natural History, 14(84), 451-454. https://doi.org/10.1080/037454809494374

Watters, J. L., Cummings, S. T., Flanagan, R. L., \& Siler, C. D. (2016). Review of morphometric measurements used in anuran species descriptions and recommendations for a standardized approach. Zootaxa, 4072(4), 477-495. https:// doi.org/10.11646/zootaxa.4072.4.6

Werneck, F. P. (2011). The diversification of eastern South American open vegetation biomes: historical biogeography and perspectives. Quaternary Science Reviews, 30(13-14), 1630-1648. https://doi.org/10.1016/j.quascirev.2011.03.009

\section{Associate Editor: Dr Mark Wilkinson}


Appendix 1. Samples included in molecular analyses, including results from DNA-based species delineation. Some of this newly analysed material was obtained through QCAZ, MPEG, INPA (H), CORBIDI, AAGUFU collections and from personal loans from Jose Manuel Padial (JMP), Santiago Castroviejo Fisher (SCF), Jucivaldo Dias Lima (FTA), Quentin Martinez (QM); Michel Blanc (AG)

\begin{tabular}{|c|c|c|c|c|c|c|c|c|c|c|c|c|}
\hline GenBank accession & Voucher & Field Number & Species_ID & mPTP & ABGD & D mPTP & P GMYC & Cons & Locality & State & Lat. & Long. \\
\hline$>$ AF467269 & & CM015 & B_raniceps & 1 & 13 & 1 & 1 & & Crique YiYi & French_Guiana & 5.483333 & -53.15 \\
\hline$>$ AY843657 & MACN37795 & & B_raniceps & 1 & 13 & 1 & 2 & 1 & Santa Fe, Vera & Argentina & -29.459031 & -60.208386 \\
\hline$>\mathrm{JF} 790127$ & & AS0169 & B_raniceps & 1 & 13 & 1 & 2 & 1 & nuflo de Chavez, San Sebastian & Bolivia & -16.359633 & -62.000050 \\
\hline$>$ JF790128 & & AS0218 & B_raniceps & 1 & 13 & 1 & 2 & 1 & Velasco, Caparu & Bolivia & -14.912117 & -61.082467 \\
\hline$>$ JF790129 & & AS0303 & B_raniceps & 1 & 13 & 1 & 2 & 1 & I Velasco, Caparu & Bolivia & -14.912117 & -61.082467 \\
\hline$>$ JF790130 & & AS0304 & B_raniceps & 1 & 13 & 1 & 2 & 1 & Velasco, Caparu & Bolivia & -14.912117 & -61.082467 \\
\hline$>$ JF790132 & & AS0306 & B_raniceps & 1 & 13 & 1 & 2 & 1 & Velasco, Caparu & Bolivia & -14.912117 & -61.082467 \\
\hline$>$ JF790133 & & AS0468 & B_raniceps & 1 & 13 & 1 & 1 & 1 & Yucuma, Los Lagos & Bolivia & -12.772 & -65.8109 \\
\hline$>$ JF790134 & & AS0570 & B_raniceps & 1 & 13 & 1 & 2 & 11 & nuflo de Chavez, San Sebastian & Bolivia & -16.359633 & -62.000050 \\
\hline$>$ KDQF01002617 & & H3905 & B_raniceps & 1 & 13 & 1 & 1 & 1 & UHE Jirau, Mutum & RO & -9.601348 & -65.0574150 \\
\hline$>\mathrm{KDQF} 01002739$ & & LPT38 & B_raniceps & 1 & 13 & 1 & 1 & 11 & Laranjal do Jari & $\mathrm{AP}$ & -0.600855 & -52.38887 \\
\hline$>$ KDQF01002991 & MPEG36750 & & B_raniceps & 1 & 13 & 1 & 2 & 1 & Canaa dos Carajas & PA & -6.075562 & -50.243245 \\
\hline$>$ KDQF01004033 & & PNA105 & B_raniceps & 1 & 13 & 1 & 2 & 11 & Parque Nacional do Araguaia & TO & -10.8166667 & -50.1833333 \\
\hline$>\mathrm{KDQF} 01004063$ & & QM052 & B_raniceps & 1 & 13 & 1 & 1 & $1 \mathrm{~s}$ & Guatemala & French_Guiana & 5.15 & -52.633333 \\
\hline$>$ KF723064 & MNKA9349 & & B_raniceps & 1 & 13 & 1 & 2 & 1 & San Sebastian & Bolivia & -16.3596 & -62.0001 \\
\hline$>$ KF723065 & SMF94093 & & B_raniceps & 1 & 13 & 1 & 2 & 1 & San Sebastian & Bolivia & -16.3596 & -62.0001 \\
\hline$>$ KF723066 & SMF94094 & & B_raniceps & 1 & 13 & 1 & 2 & 1 & San Sebastian & Bolivia & -16.3596 & -62.0001 \\
\hline$>$ KF723067 & SMF94263 & & B_raniceps & 1 & 13 & 1 & 2 & 1 & Estancia Bechler & Bolivia & -17.51720 & -63.28998 \\
\hline$>$ KF723068 & MNKA10459 & & B_raniceps & 1 & 13 & 1 & 2 & 1 & San Sebastian & Bolivia & -16.3596 & -62.0001 \\
\hline$>$ KF723069 & SMF94241 & & B_raniceps & 1 & 13 & 1 & 2 & 1 & San Sebastian & Bolivia & -16.3596 & -62.0001 \\
\hline$>$ KF723070 & SMF94246 & & B_raniceps & 1 & 13 & 1 & 2 & 1 & San Sebastian & Bolivia & -16.3596 & -62.0001 \\
\hline$>$ KU495281 & CFBHT00940 & & B_raniceps & 1 & 13 & 1 & 2 & 1 & Santa Fe do Sul & SP & -20.228 & -50.944 \\
\hline$>$ KU495282 & CFBHT02353 & & B_raniceps & 1 & 13 & 1 & 2 & 1 & Cafelandia e Cafesopolis & SP & -21.838 & -49.7 \\
\hline$>\mathrm{KU} 495283$ & CFBHT13473 & & B_raniceps & 1 & 13 & 1 & 2 & 1 & campus de Veterinaria da UFBA & Bahia & -11.935 & -38.112 \\
\hline$>$ KU495284 & CFBHT07327 & & B_raniceps & 1 & 13 & 1 & 2 & 1 & Pariquera-Acu & SP & -24.66 & -47.796 \\
\hline$>$ KU495285 & & TG146 & B_raniceps & 1 & 13 & 1 & 2 & 1 & Estreito & MA & -6.548 & -47.445 \\
\hline$>$ KU495286 & & TG265 & B_raniceps & 1 & 13 & 1 & 2 & 1 & Paranaita & MT & -9.671 & -56.482 \\
\hline$>$ KU495287 & CFBHT07328 & CFBHT07328 & B_raniceps & 1 & 13 & 1 & 2 & 1 & Pariquera-Acu & SP & -24.66 & -47.796 \\
\hline >KU495288 & & TG158 & B_raniceps & 1 & 13 & 1 & 2 & 1 & Porto Franco & MA & -6.35 & -47.406 \\
\hline$>$ MW370296 & & AG234 & B_raniceps & 1 & 13 & 1 & 1 & 1 & Comte, Terrain michel & French_Guiana & 4.679471 & -52.338531 \\
\hline$>$ MW370317 & & MTR36896 & B_raniceps & 1 & 13 & 1 & 1 & 1 & Tefé & $\mathrm{AM}$ & -3.36396 & -64.69653 \\
\hline$>$ KDQF01003728 & & MTR33845 & B_aff.lanciformis & 2 & 5 & 2 & 13 & 2 & 2 Tefe, Estrada do Abial & $\mathrm{AM}$ & -3.45944009 & -64.7509004 \\
\hline$>$ MW370318 & & MTR36907 & B_aff.lanciformis & 2 & 5 & 2 & 13 & 2 & 2 Tefé & $\mathrm{AM}$ & -3.34554 & -64.71122 \\
\hline$>\mathrm{AY} 326054$ & & WED54081 & B_lanciformis & 4 & 6 & 4 & 3 & 4 & Puyo, Pastaza & Ecuador & -1.375502 & -78.004787 \\
\hline$>$ AY843636 & & MJH564 & B_lanciformis & 4 & 6 & 4 & 4 & 4 & Loreto, Alpahuayo & Peru & -3.94403 & -73.606866 \\
\hline$>$ JN970644 & QCAZ23803 & & B_lanciformis & 4 & 6 & 4 & 3 & 4 & 4 La Pradera, Via Gualaquiza & Ecuador & -2.285 & -78.094 \\
\hline$>$ JN970645 & QCAZ23809 & & B_lanciformis & 4 & 6 & 4 & 3 & 4 & Mendez, River N of & Ecuador & -2.7291 & -78.2849 \\
\hline$>$ JN970646 & QCAZ30936 & & B_lanciformis & 4 & 6 & 4 & 3 & 4 & 4 Huino & Ecuador & -0.606 & -77.173 \\
\hline$>$ JN970647 & QCAZ18175 & & B_lanciformis & 4 & 6 & 4 & 3 & 4 & 4 Estacion Biologica Jatun Sacha & Ecuador & -1.0675 & -77.6152778 \\
\hline$>$ JN970648 & QCAZ20641 & & B_lanciformis & 4 & 6 & 4 & 3 & 4 & Estacion Cientifica Yasuni & Ecuador & -0.678194 & -76.3965555 \\
\hline$>$ JN970649 & QCAZ18237 & & B_lanciformis & 4 & 6 & 4 & 3 & 4 & Nangaritza & Ecuador & -4.335192 & -78.67974 \\
\hline$>$ JN970650 & QCAZ31017 & & B_lanciformis & 4 & 6 & 4 & 3 & 4 & I Centro Shuar Yawi & Ecuador & -4.4301 & -78.631608 \\
\hline$>$ KF157594 & & isolate 7768 & B_lanciformis & 4 & 6 & 4 & 5 & 4 & & Venezuela & NA & NA \\
\hline$>$ KP149371 & & AJC3975 & B_lanciformis & 4 & 6 & 4 & 5 & 4 & Casanare, Sabanalarga & Colombia & 4.773 & -73.037 \\
\hline$>\mathrm{KP} 149451$ & & AJC3373 & B_lanciformis & 4 & 6 & 4 & 5 & 4 & A Casanare, Sabanalarga & Colombia & 4.773 & -73.037 \\
\hline$>\mathrm{KP} 149455$ & & AJC3971 & B_lanciformis & 4 & 6 & 4 & 5 & 4 & 4 Casanare, Sabanalarga & Colombia & 4.773 & -73.037 \\
\hline$>$ KP149465 & & AJC3973 & B_lanciformis & 4 & 6 & 4 & 5 & 4 & t Casanare, Sabanalarga & Colombia & 4.773 & -73.037 \\
\hline$>$ MW370316 & & MTR36402 & B_lanciformis & 4 & 6 & 4 & 4 & 4 & 4 São Pedro, Rio Içá & AM & -3.03339 & -68.88413 \\
\hline$>$ AY843613 & NMP6V71250 & & B_aff.maculateralis & 5 & 11 & 5 & 45 & 5 & Anguilla Peru & Peru & -3.662914 & -73.924860 \\
\hline$>$ KDQF01003645 & & MTR28015 & B_aff.maculateralis & 5 & 11 & 5 & 36 & 5 & 5 Serra do Divisor & $\mathrm{AC}$ & -7.44309497 & $7-73.6576660$ \\
\hline$>\mathrm{KDQF} 01003658$ & & MTR28077 & B_aff.maculateralis & 5 & 11 & 5 & 36 & 5 & 5 Serra do Divisor & $\mathrm{AC}$ & -7.43399298 & -73.6609450 \\
\hline$>$ MW370306 & CORBIDI6182 & & B_aff.maculateralis & 5 & 11 & 5 & 36 & 5. & 5 Jenaro Herrera, Requena & Peru & -4.903812 & -73.663577 \\
\hline$>$ MW370314 & & MTR35995 & B_aff.maculateralis & 5 & 11 & 5 & 46 & 5 & Comunidade Cuiauá, Rio Içá & $\mathrm{AM}$ & -2.88619 & -68.37169 \\
\hline$>$ MW370312 & & JMP2306 & B_aff.maculateralis & 5 & 11 & 5 & 36 & 5 & quebradas_Pinsha_y_Yanayacu & Loreto & -5.12 & -73.8 \\
\hline$>$ JN970541 & QCAZ40082 & & B_maculateralis & 6 & 12 & 6 & 37 & 6 & Comunidad Santa Rosa & Ecuador & -1.02337 & -77.48359 \\
\hline$>$ JN970545 & QCAZ43710 & & B_maculateralis & 6 & 12 & 6 & 37 & 6 & 5 Coca & Ecuador & -0.47782 & -76.98982 \\
\hline$>$ JN970546 & QCAZ43712 & & B_maculateralis & 6 & 12 & 6 & 37 & 6 & 5 Coca & Ecuador & -0.47782 & -76.98982 \\
\hline$>$ JN970552 & QCAZ44452 & & B_maculateralis & 6 & 12 & 6 & 37 & 6 & Chiroisla, north bank & Ecuador & -0.57564999 & -75.8998299 \\
\hline$>$ JN970555 & QCAZ44184 & & B_maculateralis & 6 & 12 & 6 & 37 & 6 & 5 Eden & Ecuador & -0.49833 & -76.07112 \\
\hline$>$ JN970556 & QCAZ44185 & & B_maculateralis & 6 & 12 & 6 & 37 & 6 & Eden & Ecuador & -0.49833 & -76.07112 \\
\hline$>$ JN970559 & QCAZ44248 & & B_maculateralis & 6 & 12 & 6 & 37 & 6 & Eden & Ecuador & -0.49833 & -76.07112 \\
\hline$>$ JN970562 & QCAZ44636 & & B_maculateralis & 6 & 12 & 6 & 37 & 6 & 5 Huiririma & Ecuador & -0.71163 & -75.62395 \\
\hline$>$ JN970563 & QCAZ44651 & & B_maculateralis & 6 & 12 & 6 & 37 & 6 & 6 Santa Teresita & Ecuador & -0.90087 & -75.41357 \\
\hline$>$ JN970564 & QCAZ44673 & & B_maculateralis & 6 & 12 & 6 & 37 & 6 & 5 Santa Teresita & Ecuador & -0.90087 & -75.41357 \\
\hline$>$ JN970568 & QCAZ43825 & & B_maculateralis & 6 & 12 & 6 & 37 & 6 & 5 La Primavera, south bank & Ecuador & -0.44427 & -76.78685 \\
\hline$>$ JN970570 & QCAZ43827 & & B_maculateralis & 6 & 12 & 6 & 37 & 6 & 5 La Primavera, south bank & Ecuador & -0.44427 & -76.78685 \\
\hline$>$ JN970572 & QCAZ43897 & & B_maculateralis & 6 & 12 & 6 & 37 & 6 & 5 La Primavera, north bank & Ecuador & -0.431 & -76.78648 \\
\hline$>$ JN970576 & QCAZ44531 & & B_maculateralis & 6 & 12 & 6 & 37 & 6 & San Vicente & Ecuador & -0.67901 & -75.65112 \\
\hline$>$ JN970577 & QCAZ44532 & & B_maculateralis & 6 & 12 & 6 & 37 & 6 & 5 San Vicente & Ecuador & -0.67901 & -75.65112 \\
\hline$>$ JN970595 & QCAZ28401 & & B_maculateralis & 6 & 12 & 6 & 37 & 6 & 5 Cuyabeno beach & Ecuador & -0.265433 & -75.891733 \\
\hline$>$ JN970598 & QCAZ44020 & & B_maculateralis & 6 & 12 & 6 & 37 & 6 & 5 La Selva Lodge & Ecuador & -0.50868 & -76.36493 \\
\hline$>$ JN970599 & QCAZ44021 & & B_maculateralis & 6 & 12 & 6 & 37 & 6 & 5 La Selva Lodge & Ecuador & -0.50868 & -76.36493 \\
\hline$>$ JN970611 & QCAZ27940 & & B_maculateralis & 6 & 12 & 6 & 37 & 62 & 5 Zabalo & Ecuador & -0.318133 & -75.76625 \\
\hline
\end{tabular}

(continued)
2645

2646

2647

2648

2649

2650

2651

2652

2653

2654

2655
2656

2657

2658

2659

2660

2661

2662

2663

2664

2665

2666

2667

2668

2669

2670

2671

2672

2673

2674
2675

2676

2677

2678

2679

2680

2681

2682

2683

2684

2685

2686

2687

2688

2689

2690

2692

2693

2694

2695

2696

2697

2698 
Continued.

\begin{tabular}{|c|c|c|c|c|c|c|c|c|c|c|}
\hline GenBank accession & Voucher & Field Number & Species_ID & mPTP & ABGD & D mPTP & GMYC & Cons & Locality & State \\
\hline$>$ JN970612 & QCAZ28004 & & B_maculateralis & 6 & 12 & 6 & 37 & 6 & 6 Zabalo & Ecuador \\
\hline$>$ JN970613 & QCAZ28024 & & B_maculateralis & 6 & 12 & 6 & 37 & 6 & 5 Zabalo & Ecuador \\
\hline$>$ JN970523 & QCAZ18271 & & B_fasciata & 7 & 20 & 7 & 35 & 7 & 7 La Pradera, Via Gualaquiza & Ecuador \\
\hline$>$ JN970524 & QCAZ48584 & & B_fasciata & 7 & 20 & 7 & 35 & & 7 La Pradera, Via Gualaquiza & Ecuador \\
\hline$>$ JN970525 & QCAZ48585 & & B_fasciata & 7 & 20 & 7 & 35 & 7 & 7 La Pradera, Via Gualaquiza & Ecuador \\
\hline$>$ JN970526 & QCAZ48593 & & B_fasciata & 7 & 20 & 7 & 35 & 7 & 7 La Pradera, Via Gualaquiza & Ecuador \\
\hline$>$ JN970531 & QCAZ26497 & & B_fasciata & 7 & 20 & 7 & 35 & 7 & 7 Limon-Macas road, $\mathrm{km} 8$ & Ecuador \\
\hline$>$ JN970534 & QCAZ17016 & & B_fasciata & 7 & 20 & 7 & 35 & 7 & Tiink & Ecuador \\
\hline$>$ JN970535 & QCAZ17030 & & B_fasciata & 7 & 20 & 7 & 35 & 7 & 7 Tiink & Ecuador \\
\hline$>$ JN970619 & QCAZ41488 & & B_fasciata & 7 & 20 & 7 & 35 & 7 & 7 Las Orquidias & Ecuador \\
\hline$>$ JN970620 & QCAZ41575 & & B_fasciata & 7 & 20 & 7 & 35 & 7 & Miazi Alto & Ecuador \\
\hline$>$ JN970621 & QCAZ41576 & & B_fasciata & 7 & 20 & 7 & 35 & 7 & Miazi Alto & Ecuador \\
\hline$>$ JN970622 & QCAZ24866 & & B_fasciata & 7 & 20 & 7 & 35 & 7 & 7 Romerillos Alto & Ecuador \\
\hline$>$ JN970623 & QCAZ31037 & & B_fasciata & 7 & 20 & 7 & 35 & 7 & 7 Centro Shuar Yawi & Ecuador \\
\hline$>$ JN970624 & QCAZ23147 & & B_fasciata & 7 & 20 & 7 & 35 & 7 & 7 Zamora & Ecuador \\
\hline$>$ JN970625 & QCAZ23148 & & B_fasciata & 7 & 20 & 7 & 35 & 7 & Zamora & Ecuador \\
\hline$>$ JN970626 & QCAZ48583 & & B_fasciata & 7 & 20 & 7 & 35 & 7 & 7 Zamora & Ecuador \\
\hline$>$ JN970520 & QCAZ32638 & & B_almendarizae & 8 & 21 & 8 & 33 & 8 & Guamote-Macas road & Ecuador \\
\hline$>$ JN970521 & QCAZ32639 & & B_almendarizae & 8 & 21 & 8 & 33 & 8 & Guamote-Macas road & Ecuador \\
\hline$>$ JN970522 & QCAZ32645 & & B_almendarizae & 8 & 21 & 8 & 33 & 8 & Guamote-Macas road & Ecuador \\
\hline$>$ JN970527 & QCAZ25958 & & B_almendarizae & 8 & 21 & 8 & 33 & 8 & Limon via Gualaceo & Ecuador \\
\hline$>$ JN970528 & QCAZ26300 & & B_almendarizae & 8 & 21 & 8 & 33 & 8 & Limon & Ecuador \\
\hline$>$ JN970529 & QCAZ39647 & & B_almendarizae & 8 & 21 & 8 & 33 & 8 & Limon via Gualaceo & Ecuador \\
\hline$>$ JN970530 & QCAZ39650 & & B_almendarizae & 8 & 21 & 8 & 33 & 8 & Limon via Gualaceo & Ecuador \\
\hline$>$ JN970532 & QCAZ23810 & & B_almendarizae & 8 & 21 & 8 & 33 & 8 & Mendez, River $\mathrm{N}$ of & Ecuador \\
\hline$>$ JN970533 & QCAZ26438 & & B_almendarizae & 8 & 21 & 8 & 33 & 8 & San Juan Bosco & Ecuador \\
\hline$>$ JN970538 & QCAZ17944 & & B_almendarizae & 8 & 9 & 8 & 34 & 8 & Rio Hollin & Ecuador \\
\hline$>$ JN970614 & QCAZ24392 & & B_almendarizae & 8 & 9 & 8 & 34 & 8 & Rio Lagarto & Ecuador \\
\hline$>$ JN970615 & QCAZ24394 & & B_almendarizae & 8 & 9 & 8 & 34 & 8 & Rio Lagarto & Ecuador \\
\hline$>$ JN970616 & QCAZ31449 & & B_almendarizae & 8 & 9 & 8 & 34 & 8 & Rio Pastaza & Ecuador \\
\hline$>$ JN970617 & QCAZ31450 & & B_almendarizae & 8 & 9 & 8 & 34 & 8 & Rio Pastaza & Ecuador \\
\hline$>$ JN970618 & QCAZ31452 & & B_almendarizae & 8 & 9 & 8 & 34 & 8 & Rio Pastaza & Ecuador \\
\hline$>\mathrm{AY} 326056$ & KU202911 & & B_calcarata & 9 & 10 & 9 & 29 & 9 & Misahualli & Ecuador \\
\hline$>$ JN970536 & QCAZ40085 & & B_calcarata & 9 & 10 & 9 & 29 & 9 & $8 \mathrm{~km} \mathrm{~S}$ of Tena & Ecuador \\
\hline$>$ JN970537 & QCAZ40084 & & B_calcarata & 9 & 10 & 9 & 29 & 9 & $8 \mathrm{~km} \mathrm{~S}$ of Tena & Ecuador \\
\hline$>$ JN970542 & QCAZ43935 & & B_calcarata & 9 & 10 & 9 & 29 & 9 & anangu & Ecuador \\
\hline$>$ JN970547 & QCAZ43713 & & B_calcarata & 9 & 10 & 9 & 29 & 9 & Coca & Ecuador \\
\hline$>$ JN970548 & QCAZ43789 & & B_calcarata & 9 & 10 & 9 & 29 & 9 & $9 \mathrm{~km} \mathrm{~S}$ of Coca & Ecuador \\
\hline$>$ JN970550 & QCAZ44422 & & B_calcarata & 9 & 10 & 9 & 29 & 9 & Chiroisla & Ecuador \\
\hline$>$ JN970553 & QCAZ44177 & & B_calcarata & 9 & 10 & 9 & 29 & 9 & Eden & Ecuador \\
\hline$>$ JN970558 & QCAZ44247 & & B_calcarata & 9 & 10 & 9 & 29 & 9 & Eden & Ecuador \\
\hline$>$ JN970567 & QCAZ43824 & & B_calcarata & 9 & 10 & 9 & 29 & 9 & La Primavera, south bank & Ecuador \\
\hline$>$ JN970575 & QCAZ44530 & & B_calcarata & 9 & 10 & 9 & 29 & 9 & San Vicente & Ecuador \\
\hline$>$ JN970578 & QCAZ16798 & & B_calcarata & 9 & 10 & 9 & 29 & 9 & Estacion Cientifica Yasuni & Ecuador \\
\hline$>$ JN970580 & QCAZ43256 & & B_calcarata & 9 & 10 & 9 & 29 & 9 & Estacion Cientifica Yasuni & Ecuador \\
\hline$>$ JN970581 & QCAZ43259 & & B_calcarata & 9 & 10 & 9 & 29 & 9 & Estacion Cientifica Yasuni & Ecuador \\
\hline$>$ JN970584 & QCAZ20290 & & B_calcarata & 9 & 10 & 9 & 29 & 9 & Estacion Cientifica Yasuni & Ecuador \\
\hline$>$ JN970585 & QCAZ20305 & & B_calcarata & 9 & 10 & 9 & 29 & 9 & Estacion Cientifica Yasuni & Ecuador \\
\hline$>$ JN970586 & QCAZ17825 & & B_calcarata & 9 & 10 & 9 & 29 & 9 & Estacion Cientifica Yasuni & Ecuador \\
\hline$>$ JN970587 & QCAZ31446 & & B_calcarata & 9 & 10 & 9 & 29 & 9 & Estacion Cientifica Yasuni & Ecuador \\
\hline$>$ JN970588 & QCAZ14956 & & B_calcarata & 9 & 10 & 9 & 29 & 9 & Canelos & Ecuador \\
\hline$>$ JN970589 & QCAZ14958 & & B_calcarata & 9 & 10 & 9 & 29 & 9 & Canelos & Ecuador \\
\hline$>$ JN970590 & QCAZ14957 & & B_calcarata & 9 & 10 & 9 & 29 & 9 & Canelos & Ecuador \\
\hline$>$ JN970591 & QCAZ14965 & & B_calcarata & 9 & 10 & 9 & 29 & 9 & Canelos & Ecuador \\
\hline$>$ JN970597 & QCAZ25434 & & B_calcarata & 9 & 10 & 9 & 29 & 9 & La Selva Lodge & Ecuador \\
\hline$>$ JN970606 & QCAZ28181 & & B_calcarata & 9 & 10 & 9 & 29 & 9 & Cuyabeno & Ecuador \\
\hline$>$ JN970607 & QCAZ28185 & & B_calcarata & 9 & 10 & 9 & 29 & 9 & Cuyabeno & Ecuador \\
\hline$>$ JN970608 & QCAZ28197 & & B_calcarata & 9 & 10 & 9 & 29 & 9 & Cuyabeno & Ecuador \\
\hline$>$ JN970628 & & WED57649 & B_calcarata & 9 & 10 & 9 & 30 & 9 & Cuzco Amazonico & Peru \\
\hline$>$ JN970630 & & WED58712 & B_calcarata & 9 & 10 & 9 & 30 & 9 & Cuzco Amazonico & Peru \\
\hline$>$ JN970631 & & WED59271 & B_calcarata & 9 & 10 & 9 & 42 & 9 & Cuzco Amazonico & Peru \\
\hline$>$ JN970633 & & CM131 & B_calcarata & 9 & 10 & 9 & 32 & 9 & crique Margot & French_Guiana \\
\hline$>$ JN970635 & & PG105 & B_calcarata & 9 & 10 & 9 & 32 & 9 & Kaw, route & French_Guiana \\
\hline$>$ JN970636 & & PG123 & B_calcarata & 9 & 10 & 9 & 32 & 9 & Toponowini & French_Guiana \\
\hline$>$ JN970639 & & AG217 & B_calcarata & 9 & 10 & 9 & 32 & 9 & Trinite, Crique Grand Leblond & French_Guiana \\
\hline$>\mathrm{KDQF} 01000164$ & & AF0605 & B_calcarata & 9 & 10 & 9 & 32 & 9 & Trou Poisson, mare & French_Guiana \\
\hline$>$ KDQF01000277 & & AF0848 & B_calcarata & 9 & 10 & 9 & 32 & 9 & Chutes Voltaire, camp & French_Guiana \\
\hline$>$ KDQF01000291 & & AF0867 & B_calcarata & 9 & 10 & 9 & 32 & 9 & Chutes gregoire & French_Guiana \\
\hline$>$ KDQF01000338 & & AF0941 & B_calcarata & 9 & 10 & 9 & 32 & 9 & Matoury, Lac des Americains & French_Guiana \\
\hline$>\mathrm{KDQF} 01000408$ & & AF1106 & B_calcarata & 9 & 10 & 9 & 32 & 9 & Mana, Ilet Lezard rive $\mathrm{G}$ & French_Guiana \\
\hline$>$ KDQF01000537 & & AF1441 & B_calcarata & 9 & 10 & 9 & 32 & 9 & Belizon, Mare & French_Guiana \\
\hline$>$ KDQF01000583 & & AF 1543 & B_calcarata & 9 & 10 & 9 & 32 & 9 & Saul, roche bateau & French_Guiana \\
\hline$>\mathrm{KDQF} 01000587$ & & AF1549 & B_calcarata & 9 & 10 & 9 & 32 & 9 & Matoury & French_Guiana \\
\hline >KDQF01000646 & & AF1726 & B_calcarata & 9 & 10 & 9 & 32 & 9 & Chutes Voltaire & French_Guiana \\
\hline$>$ KDQF01000760 & & AF1952 & B_calcarata & 9 & 10 & 9 & 31 & 9 & Sipaliwini & Suriname \\
\hline$>$ KDQF01000908 & & AF2341 & B_calcarata & 9 & 10 & 9 & 32 & 9 & Ekini & French_Guiana \\
\hline$>$ KDQF01000986 & & AF2562 & B_calcarata & 9 & 10 & 9 & 32 & 9 & RN2 PK65 mare & French_Guiana \\
\hline$>$ KDQF01001120 & & AF 2849 & B_calcarata & 9 & 10 & 9 & 31 & 9 & Mitaraka, layon B & French_Guiana \\
\hline$>$ KDQF01001145 & & AF2931 & B_calcarata & 9 & 10 & 9 & 32 & 9 & Memora G & French_Guiana \\
\hline$>\mathrm{KDQF01001158}$ & & AF2954 & B_calcarata & 9 & 10 & 9 & 32 & 9 & Memora G & French_Guiana \\
\hline$>$ KDQF01001159 & & AF2955 & B_calcarata & 9 & 10 & 9 & 32 & 9 & Memora G & French_Guiana \\
\hline$>$ KDQF01001184 & & AF3000 & B_calcarata & 9 & 10 & 9 & 32 & 9 & Memora D & $\mathrm{AP}$ \\
\hline$>\mathrm{KDQF} 01001185$ & & AF3001 & B_calcarata & 9 & 10 & 9 & 32 & 9 & Memora D & $\mathrm{AP}$ \\
\hline$>$ KDQF01001193 & & $\mathrm{AF} 3022$ & B_calcarata & 9 & 10 & 9 & 32 & 9 & Memora D & AP \\
\hline$>$ KDQF01001194 & & AF3023 & B_calcarata & 9 & 10 & 9 & 32 & 9 & Memora D & $\mathrm{AP}$ \\
\hline$>$ KDQF01001212 & & AF3060 & B_calcarata & 9 & 10 & 9 & 32 & 9 & Mitan G & French_Guiana \\
\hline$>\mathrm{KDQF} 01001213$ & & AF3061 & B_calcarata & 9 & 10 & 9 & 32 & 9 & Mitan G & French_Guiana \\
\hline
\end{tabular}

2753

2754

2755

2756

2757

2758

2759

2760

2761

2762

2763

2764

2765

2766

2767

2768

2769

2770

2771

2773

2774

2775

2776

2777

2778

2779

2780

2781

2782
2783

2783

2784
2785
2786

2786

2787

2788

2789

2790

2791

2792

2793

2794
2795

2795

2796

2797

2798

2799

2800

2802

2803

2804

2805 2806 
2807

2808

2809

2810

2811

2812

2813

2814

2815

2816

2817

2818

2819

2820

2821

2822

2823

2824

2825

2826

2827

2828

2829

2830

2831

2832

2833

2834

2835

2836

2837

2838

2839

2840

2841

2842

2843

2844

284.

2847

2848

2849

2850

2851

2852

2853

2854

2855

2856

2857

2859

2860
Continued.

\begin{tabular}{|c|c|c|c|c|c|c|c|c|c|}
\hline GenBank accession & Voucher & Field Number & Species_ID & mPTP & ABGD & mPTP & GMYC & Cons & Locality \\
\hline >KDQF01001214 & & AF3062 & B_calcarata & 9 & 10 & 9 & 32 & 9 & Mitan G \\
\hline$>$ KDQF01001220 & & AF3069 & B_calcarata & 9 & 10 & 9 & 32 & 9 & Mitan G \\
\hline >KDQF01001277 & & AF3162 & B_calcarata & 9 & 10 & 9 & 32 & 9 & Mitan D \\
\hline$>\mathrm{KDQF} 01001278$ & & AF3164 & B_calcarata & 9 & 10 & 9 & 32 & 9 & Mitan D \\
\hline$>$ KDQF01001279 & & AF3165 & B_calcarata & 9 & 10 & 9 & 32 & 9 & Mitan D \\
\hline$>\mathrm{KDQF} 01001283$ & & AF3170 & B_calcarata & 9 & 10 & 9 & 32 & 9 & Mitan D \\
\hline$>$ KDQF01001323 & & AF3248 & B_calcarata & 9 & 10 & 9 & 32 & 9 & Trois paletuviers \\
\hline >KDQF01001331 & & AF3257 & B_calcarata & 9 & 10 & 9 & 32 & 9 & Trois paletuviers \\
\hline$>\mathrm{KDQF} 01001341$ & & AF 3270 & B_calcarata & 9 & 10 & 9 & 32 & 9 & Taparabo \\
\hline$>$ KDQF01001342 & & AF3271 & B_calcarata & 9 & 10 & 9 & 32 & 9 & Taparabo \\
\hline$>$ KDQF01001343 & & AF3272 & B_calcarata & 9 & 10 & 9 & 32 & 9 & Taparabo \\
\hline >KDQF01001344 & & AF3273 & B_calcarata & 9 & 10 & 9 & 32 & 9 & Taparabo \\
\hline$>$ KDQF01001345 & & AF3274 & B_calcarata & 9 & 10 & 9 & 32 & 9 & Taparabo \\
\hline$>$ KDQF01001353 & & AF3287 & B_calcarata & 9 & 10 & 9 & 32 & 9 & Trois paletuviers \\
\hline$>$ KDQF01001354 & & AF3288 & B_calcarata & 9 & 10 & 9 & 32 & 9 & Trois paletuviers \\
\hline$>\mathrm{KDQF} 01001355$ & & AF3289 & B_calcarata & 9 & 10 & 9 & 32 & 9 & Trois paletuviers \\
\hline >KDQF01001384 & & AF3357 & B_calcarata & 9 & 10 & 9 & 32 & 9 & Bakhuis, Creek 10k \\
\hline$>$ KDQF01001425 & & AF3454 & B_calcarata & 9 & 10 & 9 & 32 & 9 & Spari Creek \\
\hline$>\mathrm{KDQF} 01001842$ & & BM335 & B_calcarata & 9 & 10 & 9 & 41 & 9 & UHE Belo Monte \\
\hline >KDQF01001921 & & BPN0802 & B_calcarata & 9 & 10 & 9 & 31 & 9 & Kayser \\
\hline$>$ KDQF01002023 & & BPN2893 & B_calcarata & 9 & 10 & 9 & 32 & 9 & RAP Basecamp \\
\hline$>$ KDQF01002048 & & BPN3456 & B_calcarata & 9 & 10 & 9 & 31 & 9 & Mapari \\
\hline$>$ KDQF01002149 & & CAAM 38 & B_calcarata & 9 & 10 & 9 & 32 & 9 & Montagne cacao \\
\hline$>$ KDQF01002510 & & FL45 & B_calcarata & 9 & 10 & 9 & 32 & 9 & Plote PPBIO, Porto Grande \\
\hline$>$ KDQF01002600 & & $\mathrm{H} 2487$ & B_calcarata & 9 & 10 & 9 & 30 & 9 & UHE Jirau \\
\hline$>$ KDQF01002916 & MPEG30468 & & B_calcarata & 9 & 10 & 9 & 31 & 9 & Paru, FLOTA \\
\hline$>$ KDQF01003034 & MTD47753 & & B_calcarata & 9 & 10 & 9 & 32 & 9 & Kabo forestry consession \\
\hline >KDQF01003057 & MTD47926 & & B_calcarata & 9 & 10 & 9 & 32 & 9 & Iwokrama \\
\hline$>\mathrm{KDQF} 01003166$ & & MTR10021 & B_calcarata & 9 & 10 & 9 & 44 & 9 & Lago Cipotuba \\
\hline$>$ KDQF01003568 & & MTR24073 & B_calcarata & 9 & 10 & 9 & 32 & 9 & Oiapoque \\
\hline$>$ KDQF01003575 & & MTR24122 & B_calcarata & 9 & 10 & 9 & 32 & 9 & Oiapoque \\
\hline$>$ KDQF01003750 & & MTR968364 & B_calcarata & 9 & 10 & 9 & 43 & 9 & Apiacas \\
\hline >KDQF01003993 & & PK1504 & B_calcarata & 9 & 10 & 9 & 32 & 9 & Kaieteur NP \\
\hline$>$ KDQF01004113 & & QM442 & B_calcarata & 9 & 10 & 9 & 32 & 9 & Montagne de fer \\
\hline$>$ KDQF01004357 & & TJC1246 & B_calcarata & 9 & 10 & 9 & 32 & 9 & Black Water Creek \\
\hline$>\mathrm{KR} 811158$ & & MTR24072 & B_calcarata & 9 & 10 & 9 & 32 & 9 & Oiapoque \\
\hline$>$ KR811159 & & DAN012 & B_calcarata & 9 & 10 & 9 & 32 & 9 & St Georges, RN 2 PK168 \\
\hline$>$ KU221856 & & $? ?$ & B_calcarata & 9 & 10 & 9 & 29 & 9 & San Jacinto \\
\hline$>$ MF583738 & & LEO711 & B_calcarata & 9 & 10 & 9 & 29 & 9 & Putumayo, Valle del Guamuez \\
\hline$>$ MW370322 & & AF3769 & B_calcarata & 9 & 10 & 9 & 32 & 9 & Voltzberg \\
\hline$>$ MW370325 & & FTA182 & B_calcarata & 9 & 10 & 9 & 32 & 9 & Rio Amapá Grande \\
\hline >MW370328 & & JMP1569 & B_calcarata & 9 & 10 & 9 & 29 & 9 & Confluencia Supai_y_Sabalo \\
\hline$>\mathrm{AF} 467270$ & & CM??? & B_dentei & 10 & 14 & 10 & 14 & 10 & Kaw \\
\hline >KDQF01000097 & & AF0233 & B_dentei & 10 & 14 & 10 & 14 & 10 & Montagne des singes \\
\hline$>$ KDQF01000135 & & AF0540 & B_dentei & 10 & 14 & 10 & 14 & 10 & Savane virginie, layon \\
\hline$>\mathrm{KDQF} 01000227$ & & AF0727 & B_dentei & 10 & 14 & 10 & 14 & 10 & Paracou \\
\hline$>$ KDQF01000319 & & AF0913 & B_dentei & 10 & 14 & 10 & 14 & 10 & Pic Coudreau du Sud \\
\hline >KDQF01000377 & & AF1029 & B_dentei & 10 & 14 & 10 & 14 & 10 & Saul, Galbao \\
\hline$>$ KDQF01000450 & & AF 1212 & B_dentei & 10 & 14 & 10 & 14 & 10 & Trinite \\
\hline$>$ KDQF01000495 & & AF1330 & B_dentei & 10 & 14 & 10 & 14 & 10 & Saut Grand Machicou \\
\hline$>$ KDQF01000501 & & AF1337 & B_dentei & 10 & 14 & 10 & 14 & 10 & Machicou \\
\hline$>$ KDQF01000578 & & AF1529 & B_dentei & 10 & 14 & 10 & 14 & 10 & Savane Virginie \\
\hline$>$ KDQF01000637 & & AF1695 & B_dentei & 10 & 14 & 10 & 14 & 10 & Saul, Limonade \\
\hline$>$ KDQF01000846 & & AF2107 & B_dentei & 10 & 14 & 10 & 14 & 10 & RN2 corridor 5 \\
\hline$>$ KDQF01001036 & & AF2645 & B_dentei & 10 & 14 & 10 & 14 & 10 & Atachi Bakka \\
\hline$>\mathrm{KDQF} 01001065$ & & AF2697 & B_dentei & 10 & 14 & 10 & 14 & 10 & Alikene, camp polissoir \\
\hline$>$ KDQF01001109 & & AF2797 & B_dentei & 10 & 14 & 10 & 14 & 10 & Mitaraka, layon C \\
\hline >KDQF01001202 & & AF3041 & B_dentei & 10 & 14 & 10 & 14 & 10 & Memora G \\
\hline$>$ KDQF01001218 & & AF3066 & B_dentei & 10 & 14 & 10 & 14 & 10 & Mitan G \\
\hline >KDQF01001264 & & AF3146 & B_dentei & 10 & 14 & 10 & 14 & 10 & Mitan D \\
\hline$>$ KDQF01001289 & & AF3180 & B_dentei & 10 & 14 & 10 & 14 & 10 & Mitan D \\
\hline$>$ KDQF01001763 & & AP024 & B_dentei & 10 & 14 & 10 & 14 & 10 & Plote PPBIO, Porto Grande \\
\hline$>\mathrm{KDQF} 01002148$ & & CAAM37 & B_dentei & 10 & 14 & 10 & 14 & 10 & Montagne cacao \\
\hline$>$ KDQF01002205 & & CM013 & B_dentei & 10 & 14 & 10 & 14 & 10 & Kaw2 \\
\hline$>$ KDQF01002219 & & CM090 & B_dentei & 10 & 14 & 10 & 14 & 10 & Tibourou \\
\hline$>\mathrm{KDQF} 01002394$ & & DAN015 & B_dentei & 10 & 14 & 10 & 14 & 10 & St Georges, RN 2 PK168 \\
\hline$>$ KDQF01002403 & & DAN037 & B_dentei & 10 & 14 & 10 & 14 & 10 & St Georges, piste Saut Maripa \\
\hline$>\mathrm{KDQF} 01002418$ & & DSM064 & B_dentei & 10 & 14 & 10 & 14 & 10 & Savane Virginie \\
\hline$>$ KDQF01002513 & & FL90 & B_dentei & 10 & 14 & 10 & 14 & 10 & Plote PPBIO, Porto Grande \\
\hline >KDQF01002531 & & FTA170 & B_dentei & 10 & 14 & 10 & 14 & 10 & Rio Amapa Grande \\
\hline$>\mathrm{KDQF} 01003258$ & & MTR13753 & B_dentei & 10 & 14 & 10 & 14 & 10 & Serra do Navio \\
\hline$>$ KDQF01003277 & & MTR13850 & B_dentei & 10 & 14 & 10 & 14 & 10 & Lourenco \\
\hline >KDQF01003811 & & PG032 & B_dentei & 10 & 14 & 10 & 14 & 10 & Kaw2 \\
\hline >KDQF01003812 & & PG035 & B_dentei & 10 & 14 & 10 & 14 & 10 & Matecho \\
\hline$>\mathrm{KDQF} 01003843$ & & PG234 & B_dentei & 10 & 14 & 10 & 14 & 10 & Haute Wanapi \\
\hline$>$ MW370338 & & AG428 & B_dentei & 10 & 14 & 10 & 14 & 10 & Atachi Bakka \\
\hline$>$ MW370343 & & AG509 & B_dentei & 10 & 14 & 10 & 14 & 10 & Saul, Monts Belvedere \\
\hline$>$ MW370344 & & AG095/BM029 & B_dentei & 10 & 14 & 10 & 14 & 10 & Kaw2, CD6/PK 47 \\
\hline$>$ MW370346 & & AG216 & B_dentei & 10 & 14 & 10 & 14 & 10 & Trinite, Crique Grand Leblond \\
\hline$>$ MW370320 & & AF2984 & B_dentei & 10 & 14 & 10 & 14 & 10 & Mémora D \\
\hline$>$ MW370321 & & AF3628 & B_dentei & 10 & 14 & 10 & 14 & 10 & Itoupe_400 \\
\hline$>$ MW370323 & & AM009 & B_dentei & 10 & 14 & 10 & 14 & 10 & Inini_Tolenga \\
\hline$>$ MW370324 & & BOAM034 & B_dentei & 10 & 14 & 10 & 14 & 10 & Borne 4 \\
\hline$>$ MW370326 & & FTA91 & B_dentei & 10 & 14 & 10 & 14 & 10 & Rio Vila Nova \\
\hline > JN970539 & QCAZ40080 & & B_tetete & 13 & 16 & 13 & 17 & 13 & Comunidad Santa Rosa \\
\hline$>$ JN970540 & QCAZ40081 & & B_tetete & 13 & 16 & 13 & 17 & 13 & Comunidad Santa Rosa \\
\hline$>$ JN970627 & & WED60015 & B_tetete & 13 & 17 & 13 & 18 & 13 & San Jacinto \\
\hline$>$ KU221865 & & $? ? ?$ & B_tetete & 13 & 17 & 13 & 18 & 13 & San Jacinto \\
\hline
\end{tabular}

(continued)
2861

2862

2863

2864

2865

2866

2867

2868

2869

2870

2871

2872

2873

2874

2875

2876

2878

2879

2880

2881

2882

2883

2884

2885

2886

2887

2888

2889

2890

2892

2893

2894

2895

2896

2897

2898

2899

2900

2901

2902

2903

2904

2905

2906

2907
2908

2909

2910

2911

2912

2913

2914 
Continued.

\begin{tabular}{|c|c|c|c|c|c|c|c|c|c|c|}
\hline GenBank accession & Voucher & Field Number & Species_ID & mPTP & ABGD & D mPTP & GMYC & Cons & Locality & State \\
\hline$>$ JN970543 & QCAZ43977 & & B_alfaroi & 14 & 2 & 14 & 19 & 14 & 4 anangu & Ecuador \\
\hline$>$ JN970544 & QCAZ43682 & & B_alfaroi & 14 & 2 & 14 & 19 & 14 & Coca & Ecuador \\
\hline$>$ JN970549 & QCAZ44351 & & B_alfaroi & 14 & 2 & 14 & 19 & 14 & + Chiroisla & Ecuador \\
\hline$>$ JN970551 & QCAZ44425 & & B_alfaroi & 14 & 2 & 14 & 19 & 14 & + Chiroisla & Ecuador \\
\hline$>$ JN970554 & QCAZ44180 & & B_alfaroi & 14 & 2 & 14 & 19 & 14 & Eden & Ecuador \\
\hline$>$ JN970557 & QCAZ44191 & & B_alfaroi & 14 & 2 & 14 & 19 & 14 & Eden & Ecuador \\
\hline$>$ JN970560 & QCAZ44634 & & B_alfaroi & 14 & 2 & 14 & 19 & 14 & 4 Huiririma & Ecuador \\
\hline$>$ JN970561 & QCAZ44635 & & B_alfaroi & 14 & 2 & 14 & 19 & 14 & + Huiririma & Ecuador \\
\hline$>$ JN970565 & QCAZ44788 & & B_alfaroi & 14 & 2 & 14 & 19 & 14 & Nuevo Roacafuerte & Ecuador \\
\hline$>$ JN970566 & QCAZ44790 & & B_alfaroi & 14 & 2 & 14 & 19 & 14 & I Nuevo Roacafuerte & Ecuador \\
\hline$>$ JN970569 & QCAZ43826 & & B_alfaroi & 14 & 2 & 14 & 19 & 14 & 4 La Primavera, south bank & Ecuador \\
\hline$>$ JN970571 & QCAZ43894 & & B_alfaroi & 14 & 2 & 14 & 19 & 14 & La Primavera, north bank & Ecuador \\
\hline$>$ JN970573 & QCAZ44527 & & B_alfaroi & 14 & 2 & 14 & 19 & 14 & San Vicente & Ecuador \\
\hline$>$ JN970574 & QCAZ44528 & & B_alfaroi & 14 & 2 & 14 & 19 & 14 & San Vicente & Ecuador \\
\hline$>$ JN970579 & QCAZ19328 & & B_alfaroi & 14 & 2 & 14 & 19 & 14 & Estacion Cientifica Yasuni & Ecuador \\
\hline$>$ JN970582 & QCAZ43262 & & B_alfaroi & 14 & 2 & 14 & 19 & 14 & 4 Estacion Cientifica Yasuni & Ecuador \\
\hline$>$ JN970583 & QCAZ43263 & & B_alfaroi & 14 & 2 & 14 & 19 & 14 & Estacion Cientifica Yasuni & Ecuador \\
\hline$>$ JN970592 & QCAZ28272 & & B_alfaroi & 14 & 2 & 14 & 19 & 14 & A Cuyabeno beach & Ecuador \\
\hline$>$ JN970593 & QCAZ28278 & & B_alfaroi & 14 & 2 & 14 & 19 & 14 & Cuyabeno beach & Ecuador \\
\hline$>$ JN970594 & QCAZ28398 & & B_alfaroi & 14 & 2 & 14 & 19 & 14 & Cuyabeno beach & Ecuador \\
\hline$>$ JN970596 & QCAZ25410 & & B_alfaroi & 14 & 2 & 14 & 19 & 14 & La Selva Lodge & Ecuador \\
\hline$>$ JN970600 & QCAZ44025 & & B_alfaroi & 14 & 2 & 14 & 19 & 14 & t La Selva Lodge, entrance & Ecuador \\
\hline$>$ JN970601 & QCAZ44027 & & B_alfaroi & 14 & 2 & 14 & 19 & 14 & t La Selva Lodge, entrance & Ecuador \\
\hline$>$ JN970602 & QCAZ44851 & & B_alfaroi & 14 & 2 & 14 & 19 & 14 & 4 Panacocha, $2.5 \mathrm{~km} \mathrm{~S}$ of & Ecuador \\
\hline$>$ JN970603 & QCAZ44853 & & B_alfaroi & 14 & 2 & 14 & 19 & 14 & 4 Panacocha, $2.5 \mathrm{~km} \mathrm{~S}$ of & Ecuador \\
\hline$>$ JN970604 & QCAZ44856 & & B_alfaroi & 14 & 2 & 14 & 19 & 14 & Panacocha, $2.5 \mathrm{~km} \mathrm{~S}$ of & Ecuador \\
\hline$>$ JN970605 & QCAZ44858 & & B_alfaroi & 14 & 2 & 14 & 19 & 14 & Panacocha, $2.5 \mathrm{~km} \mathrm{~S}$ of & Ecuador \\
\hline$>$ JN970609 & QCAZ28240 & & B_alfaroi & 14 & 2 & 14 & 19 & 14 & Cuyabeno & Ecuador \\
\hline$>$ JN970610 & QCAZ28315 & & B_alfaroi & 14 & 2 & 14 & 19 & 14 & 4 Cuyabeno & Ecuador \\
\hline$>$ KF955305 & QCAZ50785 & & B_alfaroi & 14 & 2 & 14 & 19 & 14 & 4 Panacocha & Ecuador \\
\hline$>$ MF583737 & & LEO720 & B_alfaroi & 14 & 2 & 14 & 19 & 14 & I Putumayo, Valle del Guamuez & Colombia \\
\hline$>$ JN970634 & & CM168 & B_aff. courtoisae & 15 & 4 & 15 & 16 & 15 & Guatemala & French_Guiana \\
\hline$>$ JN970637 & & CM118 & B_aff. courtoisae & 15 & 4 & 15 & 16 & 15 & 5 Cayenne, Rorota & French_Guiana \\
\hline$>$ KDQF01000183 & & AF0641 & B_aff. courtoisae & 15 & 4 & 15 & 16 & 15 & 5 Cayenne, Rorota & French_Guiana \\
\hline$>\mathrm{KDQF} 01000335$ & & AF0937 & B_aff. courtoisae & 15 & 4 & 15 & 16 & 15 & 5 Cayenne, Vidal & French_Guiana \\
\hline$>$ KDQF01000337 & & AF0940 & B_aff. courtoisae & 15 & 4 & 15 & 16 & 15 & Matoury, Lac des Americains & French_Guiana \\
\hline$>\mathrm{KDQF} 01002239$ & & CM149 & B_aff. courtoisae & 15 & 4 & 15 & 16 & 15 & Guatemala & French_Guiana \\
\hline$>$ KDQF01002246 & & CM174 & B_aff. courtoisae & 15 & 4 & 15 & 16 & 15 & 5 Guatemala & French_Guiana \\
\hline$>\mathrm{KDQF} 01002266$ & & CM262 & B_aff. courtoisae & 15 & 4 & 15 & 16 & 15 & Guatemala & French_Guiana \\
\hline$>\mathrm{KDQF} 01002267$ & & $\mathrm{CM} 263$ & B_aff. courtoisae & 15 & 4 & 15 & 16 & 15 & 5 Guatemala & French_Guiana \\
\hline >KDQF01002271 & & $\mathrm{CM} 273$ & B_aff. courtoisae & 15 & 4 & 15 & 16 & 15 & Guatemala & French_Guiana \\
\hline$>\mathrm{KDQF} 01002424$ & & DSM100 & B_aff. courtoisae & 15 & 4 & 15 & 16 & 15 & Monsinery & French_Guiana \\
\hline$>$ KDQF01004062 & & QM051 & B_aff. courtoisae & 15 & 4 & 15 & 16 & 15 & Matiti & French_Guiana \\
\hline$>$ KDQF01004066 & & QM076 & B_aff. courtoisae & 15 & 4 & 15 & 16 & 15 & Tonnegrande grenouillere & French_Guiana \\
\hline$>$ AY549335 & AMNHA164081 & AMNHA164081 & B_courtoisae & 16 & 18 & 16 & 15 & 16 & Iwokrama, Cowfly camp & Guyana \\
\hline >EU201108 & & CM229 & B_courtoisae & 16 & 18 & 16 & 15 & 16 & Saul & French_Guiana \\
\hline$>$ JN970638 & & AG213 & B_courtoisae & 16 & 18 & 16 & 15 & 16 & 5 Trinite & French_Guiana \\
\hline$>$ JN970640 & & AG221 & B_courtoisae & 16 & 18 & 16 & 15 & 16 & 5 Trinite & French_Guiana \\
\hline$>$ JN970641 & & AF0097 & B_courtoisae & 16 & 18 & 16 & 15 & 16 & Road to Apura & Suriname \\
\hline$>$ KDQF01000489 & MNHN-RA-2020.0004 & AF1322 & B_courtoisae & 16 & 18 & 16 & 15 & 16 & 5 Saut Taconet & French_Guiana \\
\hline$>$ KDQF01000494 & MNHN-RA-2020.0005 & AF1328 & B_courtoisae & 16 & 18 & 16 & 15 & 16 & 5 Saut Grand Machicou & French_Guiana \\
\hline$>\mathrm{KDQF} 01000584$ & MNHN-RA-2020.0007 & AF1546 & B_courtoisae & 16 & 18 & 16 & 15 & 16 & 5 Saul, gros arbre & French_Guiana \\
\hline$>$ KDQF01000636 & & AF1694 & B_courtoisae & 16 & 18 & 16 & 15 & 16 & 5 Saul, Limonade & French_Guiana \\
\hline$>$ KDQF01000753 & & AF1934 & B_courtoisae & 16 & 18 & 16 & 15 & 16 & Flat de la Waki & French_Guiana \\
\hline$>$ KDQF01000829 & & AF2090 & B_courtoisae & 16 & 18 & 16 & 15 & 16 & 5 Sipaliwini & Suriname \\
\hline$>$ KDQF01000830 & & AF2091 & B_courtoisae & 16 & 18 & 16 & 15 & 16 & Sipaliwini & Suriname \\
\hline$>$ KDQF01000847 & MNHN-RA-2020.0009 & AF 2114 & B_courtoisae & 16 & 18 & 16 & 15 & 16 & 5 Sipaliwini & Suriname \\
\hline$>$ KDQF01000898 & & AF 2319 & B_courtoisae & 16 & 18 & 16 & 15 & 16 & 5 Trinite & French_Guiana \\
\hline$>$ KDQF01000909 & MNHN-RA-2020.0013 & AF 2342 & B_courtoisae & 16 & 18 & 16 & 15 & 16 & 5 Ekini & French_Guiana \\
\hline$>$ KDQF01001002 & & AF2584 & B_courtoisae & 16 & 18 & 16 & 15 & 16 & 5 Sinnamary & French_Guiana \\
\hline$>$ KDQF01001038 & MNHN-RA-2020.0002 & AF2654 & B_courtoisae & 16 & 18 & 16 & 15 & 16 & 5 Alikene, camp 1 & French_Guiana \\
\hline$>\mathrm{KDQF} 01001059$ & MNHN-RA-2020.0001 & AF2686 & B_courtoisae & 16 & 18 & 16 & 15 & 16 & Alikene, camp 1 & French_Guiana \\
\hline$>$ KDQF01001118 & MNHN-RA-2020.0014 & AF 2839 & B_courtoisae & 16 & 18 & 16 & 15 & 16 & 5 Mitaraka, layon B & French_Guiana \\
\hline$>$ KDQF01001211 & & AF3059 & B_courtoisae & 16 & 18 & 16 & 15 & 16 & Mitan G & French_Guiana \\
\hline$>$ KDQF01001424 & & AF3452 & B_courtoisae & 16 & 18 & 16 & 15 & 16 & 6 Spari Creek & Suriname \\
\hline$>$ KDQF01001456 & & AF3695 & B_courtoisae & 16 & 18 & 16 & 15 & 16 & 5 Itoupe & French_Guiana \\
\hline$>$ KDQF01001686 & MNHN-RA-2020.0003 & AM007 & B_courtoisae & 16 & 18 & 16 & 15 & 16 & 5 Inini Tolenga & French_Guiana \\
\hline$>$ KDQF01001687 & & AM008 & B_courtoisae & 16 & 18 & 16 & 15 & 16 & 5 Inini Tolenga & French_Guiana \\
\hline$>$ KDQF01001733 & & AMS394 & B_courtoisae & 16 & 18 & 16 & 15 & 16 & Ants Creek & Guyana \\
\hline$>$ KDQF01001735 & & AMS420 & B_courtoisae & 16 & 18 & 16 & 15 & 16 & 5 Land Turtle Landing Swamp & Guyana \\
\hline$>$ KDQF01001918 & & BPN0794 & B_courtoisae & 16 & 18 & 16 & 15 & 16 & 5 Ralleighvallen & Suriname \\
\hline$>\mathrm{KDQF} 01002020$ & & BPN2861 & B_courtoisae & 16 & 18 & 16 & 15 & 16 & RAP Basecamp 1, & Suriname \\
\hline$>$ KDQF01002044 & & BPN3448 & B_courtoisae & 16 & 18 & 16 & 15 & 16 & Mapari & Guyana \\
\hline$>$ KDQF01002140 & & CAAM28 & B_courtoisae & 16 & 18 & 16 & 15 & 16 & 6 Montagne cacao & French_Guiana \\
\hline$>$ KDQF01002908 & MPEG30336 & & B_courtoisae & 16 & 18 & 16 & 15 & 16 & 5 REBIO Maicuru & PA \\
\hline$>$ KDQF01002909 & MPEG30341 & & B_courtoisae & 16 & 18 & 16 & 15 & 16 & 5 REBIO Maicuru & PA \\
\hline$>$ KDQF01002910 & MPEG30342 & & B_courtoisae & 16 & 18 & 16 & 15 & 16 & 5 REBIO Maicuru & PA \\
\hline$>$ KDQF01003773 & NZCS45 & & B_courtoisae & 16 & 18 & 16 & 15 & 16 & 5 rosebel & Suriname \\
\hline$>\mathrm{KDQF} 01004011$ & & PK3520 & B_courtoisae & 16 & 18 & 16 & 15 & 16 & 5 Turtle Camp, Iwokrama & Guyana \\
\hline$>$ MW370337 & & AG422 & B_courtoisae & 16 & 18 & 16 & 15 & 16 & Atachi Bakka & French_Guiana \\
\hline$>$ MW370339 & & AG444 & B_courtoisae & 16 & 18 & 16 & 15 & 16 & Alikene & French_Guiana \\
\hline$>$ MW370340 & & AG446 & B_courtoisae & 16 & 18 & 16 & 15 & 16 & 5 Alikene & French_Guiana \\
\hline$>$ MW370342 & & AG485 & B_courtoisae & 16 & 18 & 16 & 15 & 16 & 5 Saul, Monts Belvedere & French_Guiana \\
\hline$>$ MW370345 & & AG072 & B_courtoisae & 16 & 18 & 16 & 15 & 16 & 5 Trinite, Crique Grand Leblond & French_Guiana \\
\hline$>$ MW370333 & & AF3775 & B_courtoisae & 16 & 18 & 16 & 15 & 16 & 5 Voltzberg_CI camp & Suriname \\
\hline$>$ MW370334 & & AF3791 & B_courtoisae & 16 & 18 & 16 & 15 & 16 & Voltzberg_CI camp & Suriname \\
\hline$>$ KDQF01002632 & & HJ071 & B_eucharis & 17 & 1 & 17 & 40 & 17 & 7 UHE Jirau & RO \\
\hline
\end{tabular}


Continued.

\begin{tabular}{|c|c|c|c|c|c|c|c|c|c|c|}
\hline GenBank accession & Voucher & Field Number & Species_ID & mPTP & ABGD & mPTP & GMYC & Cons & Locality & State \\
\hline$>$ KDQF01002656 & & HJ443 & B_eucharis & 17 & 1 & 17 & 28 & & UHE Jirau & RO \\
\hline$>$ KDQF01002657 & & HJ447 & B_eucharis & 17 & 1 & 17 & 28 & 17 & UHE Jirau & RO \\
\hline$>\mathrm{KDQF} 01003636$ & & MTR25798 & B_eucharis & 17 & 1 & 17 & 27 & 17 & Pacaas Novos, PARNA & $\mathrm{RO}$ \\
\hline$>\mathrm{KDQF} 01003752$ & & MTR968510 & B_eucharis & 17 & 1 & 17 & 27 & 17 & Apiacas & MT \\
\hline$>$ KDQF01003759 & & MTR977049 & B_eucharis & 17 & 1 & 17 & 27 & 17 & Juruena & MT \\
\hline$>$ MW370327 & & H2472 & B_eucharis & 17 & 1 & 17 & 28 & 17 & UHE Jirau & RO \\
\hline$>$ MW370329 & MZUSP 159228 & MTR25896 & B_eucharis & 17 & 1 & 17 & 27 & 17 & Pacaás Novos_PARNA & RO \\
\hline$>\mathrm{AY} 843632$ & AMNHA168405 & & B_heilprini & 18 & 15 & 18 & 47 & 25 & pet_trade & NA \\
\hline$>$ JN970629 & & WED57865 & B_aff.steinbachi(2) & 12 & 3 & 19 & 26 & 18 & Cuzco Amazonico & Peru \\
\hline$>$ JN970632 & & WED59350 & B_aff.steinbachi(2) & 12 & 3 & 19 & 26 & 18 & Cuzco Amazonico & Peru \\
\hline$>\mathrm{KU} 205472$ & & WED55554 & B_aff.steinbachi(2) & 12 & 3 & 19 & 26 & 18 & Puerto Maldonado & Peru \\
\hline$>$ MW370330 & AAGUFU5917 & & B aff.steinbachi(2) & 12 & 3 & 19 & 26 & 18 & Assis & $\mathrm{AC}$ \\
\hline$>$ MW370331 & AAGUFU5918 & & B_aff.steinbachi(2) & 12 & 3 & 19 & 26 & 18 & Assis & $\mathrm{AC}$ \\
\hline$>$ MW370350 & & SCF395 & B_aff.steinbachi(2) & 12 & 3 & 19 & 26 & 18 & Cocama & Peru \\
\hline$>$ KDQF01003399 & & MTR18819 & B_aff.steinbachi(1) & 11 & 3 & 11 & 22 & 11 & Lago Chaviana & $\mathrm{AM}$ \\
\hline$>\mathrm{KDQF} 01003402$ & & MTR18844 & B_aff.steinbachi(1) & 11 & 3 & 11 & 22 & 11 & Lago Chaviana & AM \\
\hline$>$ KDQF01003646 & & MTR28018 & B_aff.steinbachi(1) & 11 & 3 & 11 & 21 & 11 & Serra do Divisor & $\mathrm{AC}$ \\
\hline$>\mathrm{KDQF} 01003722$ & & MTR33822 & B_aff.steinbachi(1) & 11 & 3 & 11 & 23 & 11 & Japura, Trilha da Anta & $\mathrm{AM}$ \\
\hline$>$ MW370297 & CORBIDI11192 & & B_aff.steinbachi(1) & 11 & 3 & 11 & 20 & 11 & Saniri Malvinas & Peru \\
\hline$>$ MW370298 & CORBIDI12128 & & B_aff.steinbachi(1) & 11 & 3 & 11 & 20 & 11 & Rio Tapiche & Peru \\
\hline$>$ MW370299 & CORBIDI13035 & & B_aff.steinbachi(1) & 11 & 3 & 11 & 21 & 11 & Coronel Pontillo & Peru \\
\hline$>$ MW370307 & CORBIDI8542 & & B aff.steinbachi(1) & 11 & 3 & 11 & 20 & 11 & Poyentimari & Peru \\
\hline$>$ MW370308 & CORBIDI8698 & & B_aff.steinbachi(1) & 11 & 3 & 11 & 39 & 11 & Datem del Maranon & Peru \\
\hline$>$ MW370309 & CORBIDI8974 & & B_aff.steinbachi(1) & 11 & 3 & 11 & 20 & 11 & Rio Corrientes & Peru \\
\hline$>$ MW370310 & CORBIDI8975 & & B_aff.steinbachi(1) & 11 & 3 & 11 & 20 & 11 & Rio Corrientes & Peru \\
\hline$>$ MW370313 & & MTR35970 & B_aff.steinbachi(1) & 11 & 3 & 11 & 23 & 11 & Comunidade Cachoeirinha & $\mathrm{AM}$ \\
\hline$>$ MW370315 & & MTR36143 & B_aff.steinbachi(1) & 11 & 3 & 11 & 23 & 11 & Açaí, Rio Içá & $\mathrm{AM}$ \\
\hline$>$ MW370319 & & MTR36968 & B_aff.steinbachi(1) & 11 & 3 & 11 & 22 & 11 & Coari & $\mathrm{AM}$ \\
\hline$>$ JF790135 & & MJ1300 & B_steinbachi & 12 & 3 & 12 & 24 & 12 & Sara, Buenavista & Bolivia \\
\hline$>$ JF790136 & & MJ1301 & B_steinbachi & 12 & 3 & 12 & 24 & 12 & Sara, Buenavista & Bolivia \\
\hline$>$ JF790137 & & MJ1302 & B_steinbachi & 12 & 3 & 12 & 24 & 12 & Sara, Buenavista & Bolivia \\
\hline$>$ JF790138 & & MJ1310 & B steinbachi & 12 & 3 & 12 & 24 & 12 & Sara, Buenavista & Bolivia \\
\hline$>\mathrm{KDQF} 01001813$ & & BM048 & B_steinbachi & 12 & 3 & 12 & 25 & 12 & UHE Belo Monte & PA \\
\hline$>\mathrm{KDQF} 01001848$ & & BM355 & B_steinbachi & 12 & 3 & 12 & 25 & 12 & UHE Belo Monte & PA \\
\hline$>$ KDQF01002994 & MPEG36753 & MPEG36753 & B_steinbachi & 12 & 3 & 12 & 25 & 12 & Canaa dos Carajas & PA \\
\hline$>$ MW370300 & CORBIDI13415 & CORBIDI13415 & B_steinbachi & 12 & 3 & 12 & 24 & 12 & Tambopata & Peru \\
\hline$>$ MW370301 & CORBIDI 13417 & CORBIDI13417 & B_steinbachi & 12 & 3 & 12 & 24 & 12 & Tambopata & Peru \\
\hline$>$ MW370302 & CORBIDI13453 & CORBIDI 13453 & B_steinbachi & 12 & 3 & 12 & 24 & 12 & Tambopata & Peru \\
\hline$>$ MW370303 & CORBIDI13454 & CORBIDI13454 & B_steinbachi & 12 & 3 & 12 & 24 & 12 & Tambopata & Peru \\
\hline$>$ MW370304 & CORBIDI13482 & CORBIDI13482 & B_steinbachi & 12 & 3 & 12 & 24 & 12 & Tambopata & Peru \\
\hline$>$ MW370305 & CORBIDI15138 & CORBIDI 15138 & B_steinbachi & 12 & 3 & 12 & 24 & 12 & Tambopata & Peru \\
\hline$>$ MW370311 & & $\begin{array}{l}\text { JMP088 } \\
\text { JMP }\end{array}$ & B_steinbachi & 12 & 3 & 12 & 24 & 12 & Chalalan._Franz_Tamayo & Bolivia \\
\hline$>$ AY549317 & ZUEC12053 & & B_albopunctata & 3 & 7 & 3 & 6 & 19 & Campinas & SP \\
\hline$>$ JQ627203 & & 10 & B_albopunctata & 3 & 7 & 3 & 6 & 19 & Sao Carlos & SP \\
\hline$>\mathrm{JQ627205}$ & & 114 & B_albopunctata & 3 & 7 & 3 & 6 & 19 & Sao Carlos & SP \\
\hline$>$ KY002929 & MCNAM19674 & & B_albopunctata & 3 & 7 & 3 & 6 & 19 & & MG \\
\hline$>$ KY002930 & MCNAM 19670 & & B_albopunctata & 3 & 7 & 3 & 6 & 19 & & MG \\
\hline$>\mathrm{KY} 002955$ & MCNAM19624 & & B_albopunctata & 3 & 7 & 3 & 6 & 19 & & MG \\
\hline$>$ KY007134 & MCNAM17920 & & B_albopunctata & 3 & 7 & 3 & 6 & 19 & & MG \\
\hline$>$ KY911220 & MCNAM19707 & & B_albopunctata & 3 & 7 & 3 & 6 & 19 & & MG \\
\hline$>\mathrm{KDQF} 01002967$ & MPEG33422 & & B_sp.gralbopunctata4 & 3 & 7 & 21 & 10 & 20 & Projeto Tocantizinho & PA \\
\hline$>$ KDQF01002983 & MPEG36699 & & B_sp.gralbopunctata 4 & 3 & 7 & 21 & 10 & 20 & Itaituba & PA \\
\hline$>$ JF790116 & & AS0470 & B_leucocheila & 3 & 7 & 20 & 11 & $21 \mathrm{~A}$ & Yucuma, Los Lagos & Bolivia \\
\hline$>$ JF790117 & & MJ1326 & B_leucocheila & 3 & 7 & 20 & 11 & $21 \mathrm{~A}$ & Yucuma, Los Lagos & Bolivia \\
\hline$>$ KDQF01003124 & & MTR00212 & B_leucocheila & 3 & 7 & 20 & 11 & $21 \mathrm{~A}$ & Claudia & MT \\
\hline$>\mathrm{KDQF} 01003634$ & & MTR25723 & B_leucocheila & 3 & 7 & 20 & 11 & $21 \mathrm{~A}$ & Pacaas Novos & RO \\
\hline$>\mathrm{KDQF} 01002443$ & & ESTR00081 & B_multifasciata & 3 & 7 & 20 & 12 & $21 \mathrm{~B}$ & Carolina & MA \\
\hline$>\mathrm{KDQF} 01002465$ & & ESTR0652 & B_multifasciata & 3 & 7 & 20 & 12 & $21 \mathrm{~B}$ & Estreito & MA \\
\hline$>$ MW370347 & & $\mathrm{H} 02$ & B_multifasciata & 3 & 7 & 20 & 12 & $21 \mathrm{~B}$ & Belem & PA \\
\hline$>$ MW370348 & & H13 & B_multifasciata & 3 & 7 & 20 & 12 & $21 \mathrm{~B}$ & Belem & PA \\
\hline$>\mathrm{KDQF} 01001810$ & & BM044 & B_sp.gralbopunctata2 & 3 & 7 & 22 & 25 & 22 & UHE Belo Monte & PA \\
\hline$>\mathrm{KDQF} 01003631$ & & MTR25676 & B_sp.gralbopunctata 1 & 3 & 8 & 23 & 38 & 23 & Pacaas Novos & RO \\
\hline$>$ AY843648 & AMCC101446 & & B_sp.gr.albopunctata3 & 3 & 19 & 24 & 7 & 24 & Demerara & Guyana \\
\hline$>$ EU201110 & & AF0047 & B_sp.gr.albopunctata3 & 3 & 19 & 24 & 7 & 24 & Petit Saut & French_Guiana \\
\hline$>$ EU201111 & & CM241 & B_sp.gr.albopunctata3 & 3 & 19 & 24 & 9 & 24 & Saul & French_Guiana \\
\hline$>$ JN970642 & ROM22756 & & B_sp.gr.albopunctata3 & 3 & 19 & 24 & 7 & 24 & Baramita & Guyana \\
\hline$>$ JN970643 & ROM 28435 & & B_sp.gr.albopunctata 3 & 3 & 19 & 24 & 8 & 24 & Paramakatoi & Guyana \\
\hline$>\mathrm{KDQF} 01000029$ & & AF0048 & B_sp.gr.albopunctata3 & 3 & 19 & 24 & 7 & 24 & Petit Saut & French_Guiana \\
\hline$>\mathrm{KDQF} 01000041$ & & AF0079 & B_sp.gr.albopunctata3 & 3 & 19 & 24 & 9 & 24 & St Georges & French_Guiana \\
\hline$>\mathrm{KDQF} 01000163$ & & AF0603 & B_sp.gr.albopunctata3 & 3 & 19 & 24 & 9 & 24 & St elie, pist $\mathrm{PK} \sim 8$ & French_Guiana \\
\hline$>\mathrm{KDQF} 01000340$ & & AF0943 & B_sp.gr.albopunctata3 & 3 & 19 & 24 & 9 & 24 & Matoury & French_Guiana \\
\hline$>\mathrm{KDQF} 01000479$ & & AF 1272 & B_sp.gr.albopunctata 3 & 3 & 19 & 24 & 9 & 24 & Matiti & French_Guiana \\
\hline$>\mathrm{KDQF} 01000592$ & & $\mathrm{AF} 1570$ & B_sp.gr.albopunctata3 & 3 & 19 & 24 & 7 & 24 & St elie, piste & French_Guiana \\
\hline$>\mathrm{KDQF} 01000700$ & & AF 1832 & B_sp.gr.albopunctata3 & 3 & 19 & 24 & 9 & 24 & Montagne des Singes & French_Guiana \\
\hline$>$ KDQF01000870 & & AF2173 & B_sp.gr.albopunctata3 & 3 & 19 & 24 & 9 & 24 & Sipaliwini, air strip & Suriname \\
\hline$>\mathrm{KDQF} 01001448$ & & AF3666 & B_sp.gr.albopunctata3 & 3 & 19 & 24 & 9 & 24 & Itoupe & French_Guiana \\
\hline$>$ KDQF01002087 & & BPN3687 & B_sp.gr.albopunctata3 & 3 & 19 & 24 & 7 & 24 & Parabara, BC & Guyana \\
\hline$>\mathrm{KDQF} 01002218$ & & CM088 & B_sp.gr.albopunctata3 & 3 & 19 & 24 & 9 & 24 & Tibourou & French_Guiana \\
\hline$>\mathrm{KDQF} 01002220$ & & CM093 & B_sp.gr.albopunctata 3 & 3 & 19 & 24 & 9 & 24 & Cayenne, Montjoly & French_Guiana \\
\hline$>\mathrm{KDQF} 01002262$ & & CM242 & B_sp.gr.albopunctata3 & 3 & 19 & 24 & 9 & 24 & Saul & French_Guiana \\
\hline$>\mathrm{KDQF} 01002301$ & & CM338 & B_sp.gr.albopunctata3 & 3 & 19 & 24 & 9 & 24 & Cayenne, Montjoly & French_Guiana \\
\hline$>\mathrm{KDQF01002415}$ & & DSM048 & B_sp.gr.albopunctata 3 & 3 & 19 & 24 & 9 & 24 & Monsinery & French_Guiana \\
\hline$>\mathrm{KDQF} 01002423$ & & DSM097 & B_sp.gr.albopunctata3 & 3 & 19 & 24 & 9 & 24 & Monsinery & French_Guiana \\
\hline$>\mathrm{KDQF01003251}$ & & MTR13743 & B_sp.gr.albopunctata3 & 3 & 19 & 24 & 9 & 24 & Serra do Navio & AP \\
\hline$>$ KDQF01003256 & & MTR13750 & B_sp.gr.albopunctata3 & 3 & 19 & 24 & 9 & 24 & Serra do Navio & AP \\
\hline$>\mathrm{KDQF} 01003257$ & & MTR13751 & B_sp.gr.albopunctata3 & 3 & 19 & 24 & 9 & 24 & Serra do Navio & $\mathrm{AP}$ \\
\hline$>\mathrm{KDQF} 01003259$ & & MTR13769 & B_sp.gr.albopunctata 3 & 3 & 19 & 24 & 9 & 24 & Serra do Navio & $\mathrm{AP}$ \\
\hline
\end{tabular}

3077

3078

3079

3080

3081

3082

3083

3084

3085

3086

3087

3088

3089

3090
3091

3091
3092

3093

3094

3095

3096
3097

3098

3099

3100

3101

3102

3103

3104
3105

3106

310

310

31

3111

3112

3113

3114

31

3116

3117
3118

3118
3119

3119
3120

3121

3122

3123

3124

3125

3126

3127

3128

3129

3130 
Continued.

\begin{tabular}{|c|c|c|c|c|c|c|c|c|c|c|c|c|}
\hline GenBank accession & Voucher & Field Number & Species_ID & mPTP & ABGD & D mPTP & P GMYC & Cons & Locality & State & Lat. & Long. \\
\hline$>$ KDQF01003260 & & MTR13776 & B_sp.gr.albopunctata3 & 3 & 19 & 24 & 9 & 24 & Serra do Navio & AP & 0.9180556 & -52.0027778 \\
\hline$>\mathrm{KDQF} 01003264$ & & MTR13793 & B_sp.gr.albopunctata3 & 3 & 19 & 24 & 9 & 24 & Serra do Navio & $\mathrm{AP}$ & 0.9180556 & -52.0027778 \\
\hline$>$ KDQF01003299 & & MTR13953 & B_sp.gr.albopunctata3 & 3 & 19 & 24 & 9 & 24 & Laranjal do Jari & $\mathrm{AP}$ & -0.7166667 & -52.3833333 \\
\hline$>$ KDQF01003454 & & MTR20411 & B_sp.gr.albopunctata3 & 3 & 19 & 24 & 7 & 24 & E.E. Maraca & $\mathrm{RR}$ & 3.36977 & -61.44177 \\
\hline$>\mathrm{KDQF} 01003472$ & & MTR20525 & B_sp.gr.albopunctata 3 & 3 & 19 & 24 & 7 & 24 & E.E. Maraca & $\mathrm{RR}$ & 3.3326 & -61.3824 \\
\hline$>$ KDQF01003486 & & MTR20658 & B_sp.gr.albopunctata3 & 3 & 19 & 24 & 8 & 24 & Pacaraima & $\mathrm{RR}$ & 4.46905 & -61.13607 \\
\hline$>\mathrm{KDQF} 01003491$ & & MTR20680 & B_sp.gr.albopunctata3 & 3 & 19 & 24 & 8 & 24 & Pacaraima & $\mathrm{RR}$ & 4.473034897 & $7-61.1352092$ \\
\hline$>\mathrm{KDQF} 01003809$ & & PG026 & B_sp.gr.albopunctata3 & 3 & 19 & 24 & 9 & 24 & Cayenne, Rorota & French_Guiana & 4.874784 & -52.261119 \\
\hline$>$ KDQF01003813 & & PG036 & B_sp.gr.albopunctata3 & 3 & 19 & 24 & 9 & 24 & Kaw2 & French_Guiana & 4.516105 & -52.10053 \\
\hline$>\mathrm{KDQF} 01003845$ & & PG248 & B_sp.gr.albopunctata3 & 3 & 19 & 24 & 9 & 24 & Haute Wanapi & French_Guiana & 2.5134 & -53.8211 \\
\hline$>$ KDQF01004238 & SMNS12093 & & B_sp.gr.albopunctata3 & 3 & 19 & 24 & 7 & 24 & Bamboo landing & Guyana & 5.325 & -58.0455556 \\
\hline$>$ KDQF01004356 & & TJC1243 & B_sp.gr.albopunctata3 & 3 & 19 & 24 & 7 & 24 & Black Water Creek & Guyana & 5.07297 & -59.24899 \\
\hline$>\mathrm{KDQF} 01004364$ & & TJC1268 & B_sp.gr.albopunctata3 & 3 & 19 & 24 & 7 & 24 & NARIL & Guyana & 5.12324 & -59.11266 \\
\hline$>\mathrm{KR} 811154$ & & PG779 & B_sp.gr.albopunctata3 & 3 & 19 & 24 & 9 & 24 & St Georges, Savane 14 juillet & French_Guiana & 3.967639 & -51.87225 \\
\hline$>\mathrm{KR} 811155$ & & MTR24173 & B_sp.gr.albopunctata3 & 3 & 19 & 24 & 9 & 24 & Oiapoque & $\mathrm{AP}$ & 3.7960278 & -51.8629167 \\
\hline$>$ KR811156 & & MTR24194 & B_sp.gr.albopunctata3 & 3 & 19 & 24 & 9 & 24 & Lourenco & AP & 2.3526389 & -51.6152222 \\
\hline$>\mathrm{KR} 811157$ & & AF0749 & B_sp.gr.albopunctata3 & 3 & 19 & 24 & 9 & 24 & St Georges, savane & French_Guiana & 3.925482 & -51.788964 \\
\hline$>$ MW370336 & & AG334 & B_sp.gr.albopunctata3 & 3 & 19 & 24 & 9 & 24 & RN2 PK103 & French_Guiana & 4.36387 & -52.27747 \\
\hline$>$ MW370341 & & AG480 & B_sp.gr.albopunctata3 & 3 & 19 & 24 & 9 & 24 & Saul, Monts Belvedere & French_Guiana & 3.719347 & -53.412809 \\
\hline$>$ MW370332 & & AF3704 & B_sp.gr.albopunctata 3 & 3 & 19 & 24 & 9 & 24 & Itoupe_200 & French_Guiana & 3.01498 & -53.13286 \\
\hline$>$ MW370335 & & AF3816 & B_sp.gr.albopunctata3 & 3 & 19 & 24 & 7 & 24 & Voltzberg_CI camp & Suriname & 4.68169 & -56.18568 \\
\hline$>$ MW370349 & & QM108 & B_sp.gr.albopunctata3 & 3 & 19 & 24 & 9 & 24 & Matiti & French_Guiana & 5.035425 & -52.565573 \\
\hline
\end{tabular}

\section{Appendix 2. Molecular data acquisition}

We extracted DNA from liver or muscle tissue (thigh or toe-clip) of the 307 samples using the Wizard Genomic extraction protocol (Promega; Madison, WI, USA). We targeted a $\sim 400 \mathrm{bp}$ fragment of the 16S rDNA. We used primers N16R and N16F (Salducci et al., 2005), to which we added NNN +8 -nucleotide labels (hereafter designated as 'tags') for sample identification as all resulting PCR products were mixed into single libraries: 32 tags for forward primer (N16R) and 36 tags for reverse primer (N16F). The final volume of PCRs was $20 \mu \mathrm{l}$, and contained $2 \mu \mathrm{l}$ of DNA extract diluted 10-fold, $10 \mu \mathrm{l}$ of Amplitaq Gold ${ }^{\circledR} 360$ Master Mix (Life Technologies, Carlsbad, CA, USA), $5.84 \mu$ l of Nuclease Free Water Ambion (Thermo Fisher Scientific, MA, USA), $0.25 \mu \mathrm{M}$ of each primer and $3.2 \mu \mathrm{g}$ of Bovine Serum Albumin (Roche Diagnostic, Basel, Switzerland). We ran the PCR in duplicate for each sample, and we included blank PCR controls in the analysis using nuclease-free water as template. First, the mixture was denaturated at $95^{\circ} \mathrm{C}$ for $10 \mathrm{~min}$, followed by 40 cycles of $30 \mathrm{~s}$ at $95^{\circ} \mathrm{C}, 30 \mathrm{~s}$ at $55^{\circ} \mathrm{C}$ and $1 \mathrm{~min}$ at $72^{\circ} \mathrm{C}$; followed by a final step of $7 \mathrm{~min}$ at $72^{\circ} \mathrm{C}$. Libraries of mixed PCR products were sequenced using $2 \times 250$ paired-end reads sequencing technology through MiSeq high throughput sequencing (Illumina) at the Génopole (Toulouse, France). The resulting outputs were analysed with the OBITOOLS software suite (Boyer et al., 2016a). Paired-end reads were assembled and merged, and we used the tag attached to the primer to assign each reads to its label. Then we removed low quality reads (alignment scores $<50$, containing Ns or shorter than $50 \mathrm{bp}$ ). The resulting batch of reads was dereplicated while keeping the coverage information (number of reads merged). All sequences $<100 \mathrm{bp}$ were discarded. Eventually, all the sequences that we included in our dataset were $>380 \mathrm{bp}$ long.

\section{Mitogenome sequencing, assembling, and annotation}

For complete mitochondrial sequencing we used $200 \mathrm{ng}$ of genomic DNA per sample to build libraries at the Genotoul-GeT-PlaGe core facility (Toulouse, France). Genomic DNA was fragmented by sonication, fragments were size-selected (50-400 bp), adenylated and ligated to indexed sequencing adapters. Eight cycles of Polymerase Chain Reaction (PCR) were applied to amplify libraries before library quantification and validation. A total of 48 libraries were multiplexed to be sequenced on one lane on an Illumina HiSeq 3000 flow cell (Illumina Inc., San Diego, CA). Read assembly was performed using the ORGanelle ASseMbler (Boyer et al., 2016b), a python program developed especially for organelle and ribosomal DNA reconstructions from a genome skimming dataset. The first step is to sort and index the reads with the $o a$ index command. Then, with the oa buildgraph command, the program uses a seed (reference sequence) to assemble the reads and creates a graph with all the fragments assembled. Finally, the oa unfold command finds an optimal path in the assembly graph and reconstructs the consensus sequence (Boyer et al., 2016b).

For the oa index command, we used two options: (i) -estimate-length 0.9, which estimates the reads' length using $90 \%$ of the reads; and (ii) -bypass-filtering when the read indexing failed due to an over-filtering that resulted in an empty index. For the oa buildgraph command we used default settings in most cases, except if the assembly graph was empty due to errors in coverage estimation. In these cases, we modified the -coverage value to be slightly lower than the estimate. For the oa unfold command we used the default options as long as it was able to find the optimal assembly path. If not, we checked the assembling graph with the $y E d$ 
Graph Editor (organic layout, default parameters) and selected the green fragments (that correspond to similar seed fragments) and extracted them with the -pathoption in the oa unfold command. The fragments were then mapped onto a seed with the Geneious (R9.1.7; Biomatters Ltd, Auckland, New Zealand) map to reference function with medium-low sensitivity and one iteration. The mapping consensus was extracted and considered as a mitochondrial genome assembly.

For annotation, sequences were aligned on the MAFFT7 online server under default parameters except the use of E-INS-i strategy for rDNA, which is designed for sequences with multiple conserved domains and long gaps (Katoh et al., 2019). Then, using the Geneious R9.1.7 transfer annotation function, we annotated all the alignment sequences from a reference sequence (Anomaloglossus baeobatrachus; NC_030054). Finally, we checked that each coding sequence (CDS) began with a methionine (ATA or ATG codon for vertebrate mitochondrial genomes) and ended with a stop codon. For the final alignment, we kept the CDS, 12S-16S loci.

\section{Supplementary references}

Boyer, F., Coissac, E., Viari, A. (2016b). The ORGanelle ASseMbler. Retrieved from https://pypi.org/project/ ORG.asm/

Boyer, F., Mercier, C., Bonin, A., Le Bras, Y., Taberlet, P., \& Coissac, E. (2016a). obitools: A unix-inspired software package for DNA metabarcoding. Mol Ecol Resour, 16(1), 176-182. https://doi.org/10.1111/1755-0998.12428

Salducci, M.-D., Marty, C., Fouquet, A., \& Gilles, A. (2005). Phylogenetic relationships and biodiversity in Hylids (Anura: Hylidae) from French Guiana. Comptes Rendus Biologies, 328(10-11), 1009-1024. https://doi.org/10.1016/j. crvi.2005.07.005 
Appendix 3. Completion for the mitogenomic matrix

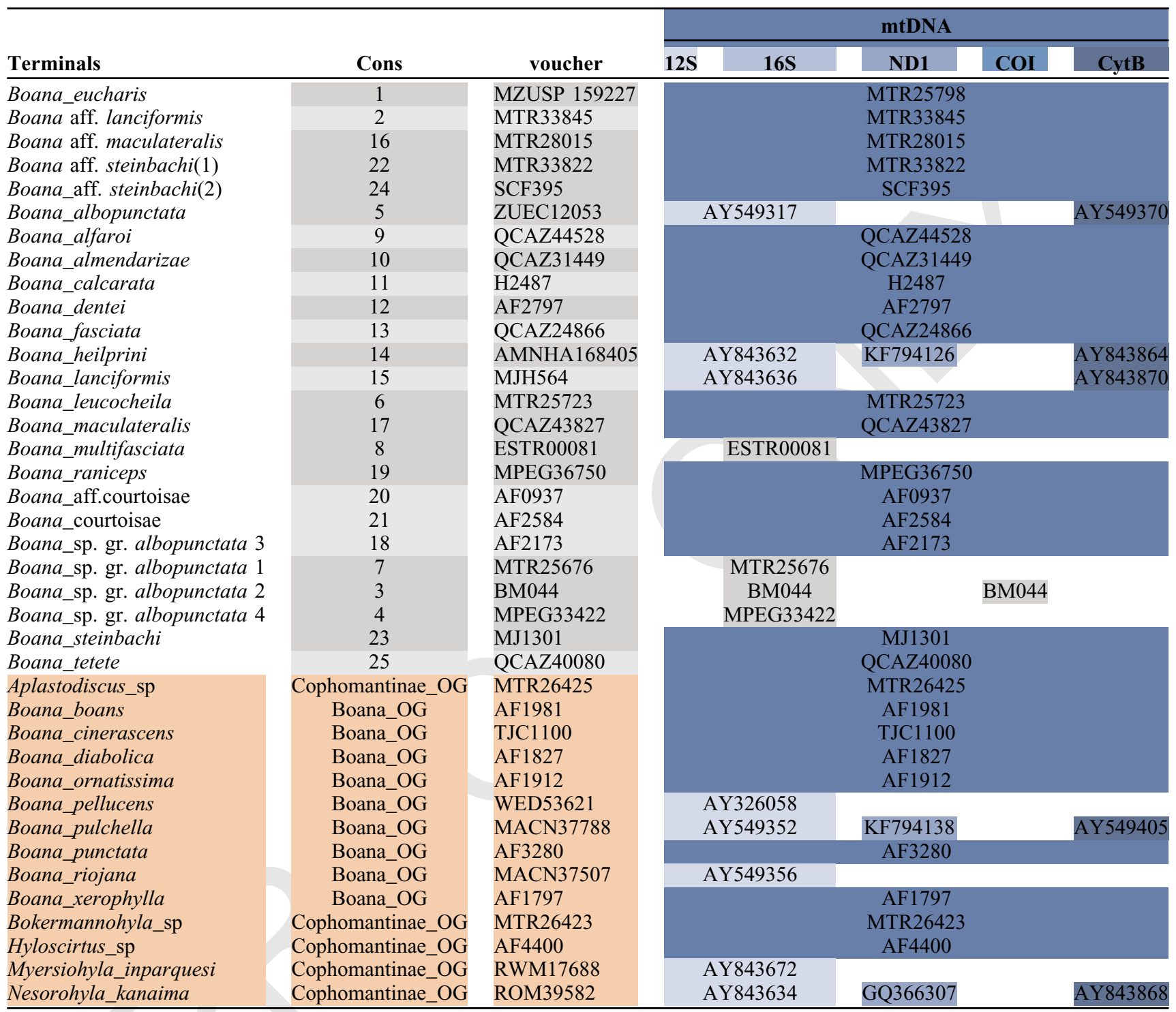




\section{Appendix 4. Detailed information on sound files analyzed for this study. Letters following numbers of recordings in AAG-UFU collection (e.g. 1a-e) indicate the number of sound files for each recorded male}

\section{Boana courtoisae}

Sound file - MNHN-SO-2020-2943. Unvouchered recording. Recorded from Rorota, French Guiana.

Sound file - MNHN-SO-2020-2944. Unvouchered recording. Recorded from Rorota, French Guiana.

Sound file - MNHN-SO-2020-2946. Unvouchered recording. Recorded from Rorota, French Guiana.

Sound file - MNHN-SO-2020-2945. Unvouchered recording. Recorded from Rorota, French Guiana.

Sound file - MNHN-SO-2020-2947. Unvouchered recording. Recorded from Sipaliwini, Suriname.

Sound file - MNHN-SO-2020-2948. Unvouchered recording. Recorded from Paletuviers, French Guiana.

\section{Boana eucharis}

Sound files - Boana_eucharisAltaFlorestaMT1aeDLB_AAGm671/ MNHN-SO-2020-2949-53; recorded on 11 January 2019 , at $7: 44 \mathrm{pm}$, air $24.5^{\circ} \mathrm{C}$. voucher: AAG-UFU 6503 (holotype). Recorded from Alta Floresta, Mato Grosso, Brazil.

Sound files - Boana_eucharisAltaFlorestaMT2acDLB_AAGm671/ MNHN-SO-2020-2954-56; recorded on 11 January 2019 , at 8:04 pm, air $24.5^{\circ} \mathrm{C}$. Voucher: AAG-UFU 6504 (paratype). Recorded from Alta Floresta, Mato Grosso, Brazil.

Sound file - Boana_eucharisAltaFlorestaMT3acDLB_AAGm671/ MNHN-SO-2020-2957-59; recorded on 11 January 2019 , at $8: 10 \mathrm{pm}$, air $24.5^{\circ} \mathrm{C}$. Unvouchered recording. Recorded from Alta Floresta, Mato Grosso, Brazil.

Sound file - Boana_eucharisAltaFlorestaMT4a-bDLB_ AAGm671/ MNHN-SO-2020-2960-61; recorded on 11 January 2019, at 9:05 pm, air $24.5^{\circ} \mathrm{C}$. Unvouchered recording. Recorded from Alta Floresta, Mato Grosso, Brazil.

Sound file - Boana_eucharisAltaFlorestaMT5a-iPM AAGm671/ MNHN-SO-2020-2962-70; recorded on 20 January 2020 , at $8: 02 \mathrm{pm}$, air $25.1^{\circ} \mathrm{C}$. Voucher: AAGUFU 6901 (paratype). Recorded from Alta Floresta, Mato Grosso, Brazil.

Sound file - Boana_eucharisAltaFlorestaMT6a-bAA Gm671/ MNHN-SO-2020-2971-72; recorded on 20 January 2020 , at $9: 18 \mathrm{pm}$, air $25.0^{\circ} \mathrm{C}$. Unvouchered recording. Recorded from Alta Floresta, Mato Grosso, Brazil.
Sound file - Boana_eucharisAltaFlorestaMT7a-fAA Gm671/ MNHN-SO-2020-2973-78 and MNHN-SO2020-2980-81; recorded on 20 January 2020, at $9: 48 \mathrm{pm}$, air $25.0^{\circ} \mathrm{C}$. Unvouchered recording. Recorded from Alta Floresta, Mato Grosso, Brazil.

\section{Boana steinbachi}

Sound file - MNHN-SO-2020-2934 . Voucher: SMF88394.

Recorded from Buenavista, Sara province, Bolivia.

Sound file - MNHN-SO-2020-2935. Voucher: SMF88397. Recorded from Buenavista, Sara province, Bolivia.

Sound file - MNHN-SO-2020-2936. Unvouchered recording. Recorded from Rio Matos, Beni, Bolivia.

Sound file - MNHN-SO-2020-2937. Unvouchered recording. Recorded from Rio Matos, Beni, Bolivia.

Sound file - MNHN-SO-2020-2938. Unvouchered recording. Recorded from Tambopata, Madre de Dios, Peru.

Sound file - 14-Hyla fasciata. Unvouchered recording. Recorded from Tambopata, Madre de Dios, Peru.

Sound file - ML198328. Unvouchered recording. Recorded from Tambopata, Madre de Dios, Peru.

Sound file - ML198676. Unvouchered recording. Recorded from Tambopata, Madre de Dios, Peru.

Sound file - ML198677. Unvouchered recording. Recorded from Tambopata, Madre de Dios, Peru.

Sound file - ML222268. Unvouchered recording. Recorded from Cuzco Amazonico, Peru.

Sound file - Boana_steinbachiAssisBrasilAC1a-d TRC_AAGm671/ MNHN-SO-2020-2939-42; recorded on 12 February 2017 , at 8:00 pm, air $26.2^{\circ} \mathrm{C}$. Voucher: AAGUFU 5917. Recorded from Assis Brasil, Acre, Brazil.

Sound file - FNJV12840; recorded on 4 December 1986 , at 8:00 pm, air $23.5^{\circ} \mathrm{C}$. Unvouchered recording. Recorded from Altamira, Pará, Brazil.

Sound file - FNJV12841; recorded on 7 December 1986 , at $10: 00 \mathrm{pm}$, air $23.5^{\circ} \mathrm{C}$. Unvouchered recording. Recorded from Altamira, Pará, Brazil.

\section{Appendix 5. Details and justifications for the identification of these OTUs and their respective geographic ranges \\ Boana raniceps (1 OTU)}

Boana raniceps is recovered as a single OTU, distantly related from the rest of the species and widely distributed latitudinally from Argentina to French Guiana and longitudinally from Bahia to central Amazonia throughout the Cerrado and Chaco. This distribution encompasses the type locality 'Paraguay'. 


\section{The Boana albopunctata clade (9 OTUs)}

Boana albopunctata is restricted to a small range in the states of Sao Paulo and Minas Gerais, encompassing its type locality. However, additional data (Prado, Haddad, \& Zamudio, 2012) indicate that the actual range of this OTU extends at least to the states of Goiás, Mato Grosso do Sul, and Paraná. However, the other populations previously identified as B. albopunctata further north in the Cerrado and in Amazonia probably belong to a distinct species, as already suggested by Prado et al. (2012).

Boana leucocheila is tentatively assigned to one of the OTU distributed in Mato Grosso, Rondônia, and Bolivia. This distribution encompasses the type locality (Caramaschi \& de Niemeyer, 2003) and other populations also reported in Mato Grosso (Pansonato, Ávila, Kawashita-Ribeiro, \& Morais, 2011). The examination of specimens (MTR) corroborated this identification.

Boana multifasciata was sampled at the type locality in Belém, Pará state, and in two localities (Carolina and Estreito) at the border between the states of Maranhão and Tocantins. This species may be circumscribed to the northern part of the Cerrado and adjacent parts of Amazonia. The range of this species probably extends further southward at least in northern Cerrado. However, the Amazonian populations previously identified as $B$. multifasciata are suggested to belong to a distinct species (see hereafter).

The populations previously identified as Boana multifasciata (B. aff. albopunctata 3) from the Guiana Shield, and as Boana albopunctata from Belo Monte, Pará (B. aff. albopunctata 2), Itaituba, Pará (B. aff. albopunctata 4 ), and Rondônia (B. aff. albopunctata 1 ) are suggested to belong to yet undescribed species. The two taxa (B. paranaiba and B. caiapo) that could not be included in our analysis are described from localities in the Cerrado (see Carvalho, Giaretta, \& Facure, 2010; Pinheiro et al., 2018), and are thus unlikely to correspond to these Amazonian OTUs. Given the phenotypic differences observed among B. leucocheila, $B$. albopunctata, and B. multifasciata, these OTUs may also be phenotypically distinct from each other (Caramaschi \& de Niemeyer, 2003; Carvalho et al., 2010). Nevertheless, we did not examine variation across these populations because it was outside the scope of our study. Therefore, these OTUs should be considered as Unconfirmed Candidate Species (UCS).

Boana lanciformis has a wide range in Western Amazonia (Peru, Ecuador Colombia, and Amazonas State in Brazil), encompassing its type locality in the District Pebas, Region of Loreto, Peru (incorrectly ascribed to Ecuador by Cope). However, one population from Téfé (Amazonas, Brazil), in central Amazonia, is found genetically distinct and identified as a separate OTU. We did not examine variation across these populations, thus, this OTU will be considered as UCS. Interestingly, the range of these two OTUs does not overlap with neither Boana raniceps nor any of the other OTU related to B. albopunctata.

\section{The Boana calcarata clade (5 OTUs)}

Boana calcarata is recovered as a single OTU largely distributed throughout Amazonia, thus encompassing its type locality in Guyana.

Boana almendarizae and B. fasciata display ranges circumscribed to the slopes of the Andes of Ecuador (type localities in Morona Santiago and ZamoraChinchipe provinces, respectively) and northern Peru (Amazonas province), as already established by Caminer and Ron (2014). Similarly, B. maculateralis displays a small range in Ecuador, but in the lowlands. Its actual range extends at least to Meta (Acosta-Galvis et al., 2018) and Guaviare (Medina-Rangel, Méndez-Galeano, \& Calderón-Espinosa, 2019) in Colombia, and probably to adjacent Peru. However, the populations from Loreto in northern Peru previously documented by Caminer and Ron (2014) as distinct from B. maculateralis, cluster with other populations from Loreto in northern Peru, and from Rio Içá (Amazonas) and Serra do Divisor (Acre) in north-western Brazil, forming a distinct OTU (B. aff. maculateralis). Populations from Leticia, in south-eastern Colombia (Acosta-Galvis et al., 2018), Japurá (Amazonas) in north-western Brazil (Rojas-Zamora et al., 2017), and from Manu National Park in southern Peru (Caminer \& Ron, 2014) probably display this lineage as well. We did not examine variation across these populations, thus, this OTU will be considered as UCS.

\section{The Boana steinbachi clade (9 OTUs)}

Boana dentei displays a small range in the easternmost part of the Guiana Shield lowlands (Amapá and French Guiana) encompassing its type locality (Serra do Navio).

Boana alfaroi and $B$. tetete both display small ranges in Amazonian lowlands of Ecuador, as documented by Caminer and Ron (2014). Moreover, the range of $B$. alfaroi extends further north to Putumayo (Meza-Joya, Ramos-Pallares, \& Hernández-Jaimes, 2019) and Caquetá (Medina-Rangel et al., 2019) in Colombia. However, the record from Acre provided by Carvalho et al. (2017) corresponds to $B$. aff. steinbachi 1 (see below). The range of $B$. tetete extends to Loreto, Peru, 
confirming records from Acosta-Galvis et al. (2018). Nevertheless, their record from Leticia most likely corresponds to either B. alfaroi or B. aff. steinbachi 1 .

Boana steinbachi occurs from Bolivia (type locality) to south-eastern Peru (Tambopata, Madre de Dios), and more surprisingly in eastern Brazilian Amazonia (Pará). This extensive range with a wide gap between Bolivia and Pará and the fact that acoustic data associated with voucher specimens were not available from the Pará populations did not allow us to confirm the taxonomic identity of these populations as conspecific with nominal B. steinbachi (see below). Another group of related populations extends widely in Western Amazonia of Peru, Colombia, and Brazil, forming a distinct OTU (B. aff. steinbachi 1). The populations previously identified as Boana alfaroi (Carvalho, Bang, Teixeira, \& Giaretta, 2017) belong to this OTU, but since we did not find any phenotypic diagnosis among the OTUs within this clade, we treated them as conspecific with B. steinbachi. Additional populations from southern and eastern Peru (lower Madre de Dios River, Madre de Dios and Cocama, Ucayali) are identified as a distinct small-range OTU (B. aff. steinbachi 2). We examined the type series of Boana steinbachi, examined the morphology and analysed calls of a series of topotypes, and provided an amended diagnosis of the nominal species.
Populations from Rondônia (Pacaás Novos and Jirau) and Mato Grosso (Apiacás, Juruena, and Alta Floresta) form a distinct small-range lineage identified as a distinct OTU (Boana sp. 1). These populations were so far confused with B. fasciata (Avila \& KawashitaRibeiro 2011; Lima, Keller, \& Rebelo, 2017). We assessed the phylogenetic relationships and morphological and acoustic characters of Boana sp. 1, which led us to describe it herein as a new species (see below).

Populations from the Eastern Guiana Shield form two additional OTUs: Boana sp. 2 which extends throughout the region, and Boana sp. 3 which is circumscribed to coastal French Guiana. These populations were previously identified as Boana fasciata (Fouquet et al., 2007; Lescure \& Marty 2000; Dewynter et al., 2008) and subsequently suggested to belong to an unnamed species (Funk et al., 2012; Caminer \& Ron 2014; Cole, Townsend, Reynolds, MacCulloch, \& Lathrop, 2013; Fouquet, Vidal, \& Dewynter, 2019). We examined morphological and acoustic characters of specimens of Boana sp. 2 and described it herein as a new species (see below). However, we tentatively consider Bana sp. 3 as conspecific with Boana sp. 2 since no clear phenotypic differentiation was found across Guiana Shield populations. 
Appendix 6A. Descriptive statistics of type 1 calls of the Boana steinbachi clade. Data presented as mean \pm SD (range)

\section{Appendix 6AB. Descriptive statistics of type 1 calls of the analysed species. Data presented as mean \pm SD (range)}

\begin{tabular}{|c|c|c|c|c|}
\hline & Boana eucharis sp. nov. & Boana courtoisae sp. nov. & Boana steinbachi & Boana dentei (Marinho et al., 2020) \\
\hline $\begin{array}{l}\text { Call duration } \\
(\mathrm{ms})\end{array}$ & $\begin{array}{c}290 \pm 42 \\
(100-430)\end{array}$ & $\begin{array}{c}120 \pm 31 \\
(140-240)\end{array}$ & $\begin{array}{c}280 \pm 49 \\
(130-430)\end{array}$ & $\begin{array}{l}70 \pm 10 \\
(60-90)\end{array}$ \\
\hline Number of notes & $3-7$ & $3-4$ & $3-8$ & 1 \\
\hline $\begin{array}{l}\text { Note duration } \\
\text { (ms) }\end{array}$ & $\begin{array}{l}13 \pm 5 \\
(3-60)\end{array}$ & $\begin{array}{l}18 \pm 3 \\
(5-36)\end{array}$ & $\begin{array}{l}15 \pm 7 \\
(4-52)\end{array}$ & - \\
\hline $\begin{array}{l}\text { Note interval } \\
(\mathrm{ms})\end{array}$ & $\begin{array}{c}61 \pm 4 \\
(27-82)\end{array}$ & $\begin{array}{c}47 \pm 5 \\
(20-69)\end{array}$ & $\begin{array}{l}41 \pm 10 \\
(1-67)\end{array}$ & - \\
\hline $\begin{array}{l}\text { Dominant frequency } \\
(\mathrm{Hz})\end{array}$ & $\begin{array}{c}2319.28 \pm 113.18 \\
(1981.10-2971.60)\end{array}$ & $\begin{array}{c}2259.18 \pm 216.22 \\
(1636.50-2454.80)\end{array}$ & $\begin{array}{c}2396.51 \pm 312.85 \\
(1687.50-3402.20)\end{array}$ & $\begin{array}{c}2400.00 \pm 300.00 \\
(1900.00-2900.00)\end{array}$ \\
\hline $\begin{array}{l}\text { Maximum frequency } \\
(\mathrm{Hz})\end{array}$ & $\begin{array}{c}2841.46 \pm 475.71 \\
(2196.40-4220.50)\end{array}$ & $\begin{array}{c}2860.05 \pm 136.21 \\
(2627.10-3100.80)\end{array}$ & $\begin{array}{c}3336.38 \pm 331.49 \\
(2713.28-4478.90)\end{array}$ & $\begin{array}{c}2800.00 \pm 200.00 \\
(2500.00-3100.00)\end{array}$ \\
\hline $\begin{array}{l}\text { Minimum frequency } \\
(\mathrm{Hz})\end{array}$ & $\begin{array}{c}1964.83 \pm 109.88 \\
(1722.70-2250.00)\end{array}$ & $\begin{array}{c}1678.49 \pm 230.85 \\
(1335.10-1875.00)\end{array}$ & $\begin{array}{c}1664.90 \pm 138.50 \\
(1355.10-1981.10)\end{array}$ & $\begin{array}{c}1600.00 \pm 100.00 \\
(1450.00-1800.00)\end{array}$ \\
\hline $\begin{array}{l}\text { Call rise time } \\
(\%)\end{array}$ & $\begin{array}{l}45 \pm 10 \\
(2-97)\end{array}$ & $\begin{array}{l}42 \pm 18 \\
(7-94)\end{array}$ & $\begin{array}{r}48 \pm 57 \\
(2-98)\end{array}$ & $\begin{array}{c}25 \pm 7 \\
(15-37)\end{array}$ \\
\hline Recorded males & 7 & 5 & 13 & 9 \\
\hline $\begin{array}{l}\text { Air temperature } \\
\left({ }^{\circ} \mathrm{C}\right)\end{array}$ & $25.1-25.4$ & - & & $24.5-25.5$ \\
\hline
\end{tabular}

\begin{tabular}{lcccc}
\hline & Boana eucharis sp. nov. & Boana courtoisae sp. nov. & Boana steinbachi & $\begin{array}{c}\text { Boana dentei } \\
\text { (Marinho et al., 2020) }\end{array}$ \\
\hline Call duration & $48 \pm 5$ & $53 \pm 16$ & $48 \pm 5$ & $160 \pm 30$ \\
$(\mathrm{~ms})$ & $(29-64)$ & $(39-79)$ & $(29-64)$ & $(120-200)$ \\
Dominant frequency & $2515.11 \pm 245.16$ & $21912.14 \pm 312.93$ & $2469.43 \pm 175.63$ & $1900.00 \pm 300.00$ \\
$(\mathrm{~Hz})$ & $(1938.06-3143.80)$ & $(1679.70-2411.70)$ & $(1687.50-2812.50)$ & $(1600.00-2200.00)$ \\
Maximum frequency & $3083.52 \pm 142.57$ & $2876.84 \pm 186.20$ & $3146.92 \pm 353.97$ & $2500.00 \pm 100.00$ \\
$(\mathrm{~Hz})$ & $(2712.20-3421.90)$ & $(2627.10-3143.80)$ & $(2713.20-4522.00)$ & $(2300.00-2600.00)$ \\
Minimum frequency & $1861.25 \pm 56.89$ & $1533.20 \pm 112.30$ & $1724.92 \pm 62.75$ & $1500.00 \pm 100.00$ \\
$(\mathrm{~Hz})$ & $(1593.50-2067.20)$ & $(1464.30-1722.70)$ & $(1453.10-2015.60)$ & $(1300.00-1600.00)$ \\
Note rise time & $48 \pm 7$ & $57 \pm 16$ & $70 \pm 7$ & $41 \pm 14$ \\
$(\%)$ & $(24-78)$ & $(39-82)$ & $(18-60)$ & $26-65$ \\
Recorded males & 7 & 5 & 5 & 9 \\
Air temperature & $25.1-25.4$ & - & - & $24.5-25.5$ \\
$\left({ }^{\circ} \mathrm{C}\right)$ & & & & \\
\hline
\end{tabular}


Appendix 7. Descriptive statistics of morphometric traits (in $\mathbf{m m}$ ) from specimens of the Boana steinbachi clade: topotypes and additional specimens of $B$. steinbachi, and the type series of $B$. eucharis sp. nov. and $B$. courtoisae sp. nov. Data presented as mean \pm SD (range). Abbreviations are: $S V L=$ snout-vent length; $\mathrm{FOOT}=$ foot length; $\mathrm{HL}=$ head length; $\mathrm{HW}=$ head width; $\mathrm{ED}=$ eye diameter; $T D=$ tympanum diameter; $T L=$ tibia length; $F L=$ femur length; $\mathbf{C L}=$ calcaneal appendage length. ${ }^{*}$ sample sizes for $\mathrm{CL}$ are as follows: $B$. steinbachi $(\mathrm{N}=6$ males), B. eucharis sp. nov. ( $\mathrm{N}=7$ males), and $B$. courtoisae sp. nov. (all specimens were measured)

\begin{tabular}{|c|c|c|c|c|c|}
\hline & \multicolumn{2}{|c|}{ Boana steinbachi } & \multirow{2}{*}{$\begin{array}{c}\text { Boana eucharis sp. nov. } \\
\text { Males } \\
\mathbf{N}=7\end{array}$} & \multicolumn{2}{|c|}{ Boana courtoisae sp. nov. } \\
\hline & $\begin{array}{c}\text { Males } \\
\mathbf{N}=\mathbf{1 8}\end{array}$ & $\begin{array}{c}\text { Females } \\
N=6\end{array}$ & & $\begin{array}{c}\text { Males } \\
\mathbf{N}=13\end{array}$ & $\begin{array}{c}\text { Females } \\
\mathbf{N}=\mathbf{3}\end{array}$ \\
\hline \multirow[t]{2}{*}{ SVL } & $33.6 \pm 1.6$ & $44.9 \pm 2.1$ & $32.7 \pm 1.2$ & $33.1 \pm 1.9$ & $44.2 \pm 1.5$ \\
\hline & $(30.4-37.4)$ & $(42.5-48.8)$ & $(30.8-34.7)$ & $(30.8-35.9)$ & $(43.0-45.9)$ \\
\hline \multirow[t]{2}{*}{ FL } & $14.0 \pm 1.4$ & $18.0 \pm 0.8$ & $13.3 \pm 0.4$ & $13.6 \pm 1.1$ & $19.0 \pm 0.5$ \\
\hline & $(11.4-16.6)$ & $(16.6-18.8)$ & $(12.7-13.7)$ & $(11.8-15.5)$ & $(18.6-19.5)$ \\
\hline \multirow[t]{2}{*}{ HL } & $11.5 \pm 2.1$ & $10.9 \pm 0.3$ & $12.1 \pm 0.7$ & $12.1 \pm 0.8$ & $15.5 \pm 0.6$ \\
\hline & $(7.9-13.4)$ & $(10.5-11.4)$ & $(10.7-12.9)$ & $(10.8-14.0)$ & $(15.0-16.1)$ \\
\hline \multirow[t]{2}{*}{ HW } & $10.8 \pm 0.8$ & $15.0 \pm 0.4$ & $10.7 \pm 0.5$ & $11.3 \pm 1.0$ & $14.5 \pm 1.0$ \\
\hline & $(9.2-12.1)$ & $(14.4-15.5)$ & $(10.1-11.8)$ & $(10.0-12.9)$ & $(13.6-15.6)$ \\
\hline \multirow[t]{2}{*}{ ED } & $4.0 \pm 0.4$ & $4.3 \pm 0.4$ & $4.2 \pm 0.2$ & $4.7 \pm 0.4$ & $5.1 \pm 0.6$ \\
\hline & $(3.2-4.9)$ & $(3.9-5.1)$ & $(3.8-4.7)$ & $(4.0-5.4)$ & $(4.4-5.5)$ \\
\hline \multirow[t]{2}{*}{ TD } & $2.1 \pm 0.3$ & $2.5 \pm 0.5$ & $2.0 \pm 0.2$ & $2.1 \pm 0.2$ & $2.4 \pm 0.00$ \\
\hline & $(1.3-2.5)$ & $(1.9-2.9)$ & $(1.6-2.2)$ & $(1.8-2.3)$ & \\
\hline \multirow[t]{2}{*}{ TL } & $18.7 \pm 2.1$ & $22.6 \pm 1.4$ & $18.4 \pm 0.7$ & $19.1 \pm 1.1$ & $26.1 \pm 0.6$ \\
\hline & $(14.2-21.7)$ & $(20.5-24.3)$ & $(17.1-19.6)$ & $(17.7-20.9)$ & $(25.6-26.7)$ \\
\hline \multirow[t]{2}{*}{ THL } & $18.8 \pm 1.9$ & $25.4 \pm 0.9$ & $16.7 \pm 1.4$ & $17.5 \pm 1.2$ & $23.7 \pm 1.5$ \\
\hline & $(14.8-21.1)$ & $(24.4-27.1)$ & (14.9-18.6) & $(15.8-19.5)$ & $(22.1-25.1)$ \\
\hline \multirow[t]{2}{*}{$\mathrm{CAL}^{*}$} & $0.5 \pm 0.1$ & - & $0.2 \pm 0.0$ & $0.5 \pm 0.1$ & $0.7 \pm 0.1$ \\
\hline & $(0.3-0.6)$ & & $(0.1-0.2)$ & $(0.3-0.6)$ & $(0.6-0.7)$ \\
\hline
\end{tabular}

\section{Appendix 8. Additional Boana courtoisae sp. nov. specimens}

Males:

AF1925, AF1934: French Guiana, Flat de la Waki

AF2319: French Guiana, Trinité,

AF3059, AF3070: French Guiana, Mitan

AF3694: French Guiana, Itoupe

AM008: French Guiana, Inini Tolenga

AF2115, AF2195: Suriname, Sipaliwini

AF3452, Suriname, Spari Creek

AF3775, AF3784: Suriname, Voltzberg, CI camp

Females:

AF2584, French Guiana, Sinnamary

AF1694, French Guiana, Saul - Limonade

AF1544, French Guiana, Saul - Gros arbre 
A. Fouquet et al.

\section{Appendix 9. BioGeoBears models}

\begin{tabular}{|c|c|c|c|c|c|c|}
\hline Models & LnL & d & e & $\mathbf{j}$ & AIC & DAIC \\
\hline$\overline{\mathrm{DEC}+\mathrm{J}}$ & -46.445 & $6.89 \mathrm{E}-03$ & $1.00 \mathrm{E}-12$ & 0.040 & 98.89 & 0 \\
\hline DIVAlike $+\mathrm{J}$ & -46.798 & $9.59 \mathrm{E}-03$ & $2.00 \mathrm{E}-09$ & 0.033 & 99.6 & 0.71 \\
\hline BAYAREA $+\mathrm{J}$ & -50.002 & $6.96 \mathrm{E}-3$ & $1.00 \mathrm{E}-12$ & 0.047 & 106 & 7.11 \\
\hline $\mathrm{DEC}$ & -52.78 & 0.015 & $1.00 \mathrm{E}-12$ & 0 & 109.6 & 10.71 \\
\hline DIVAlike & -55.922 & 0.014 & $1.00 \mathrm{E}-12$ & 0 & 115.8 & 16.91 \\
\hline BAYAREA & -61.097 & 0.014 & 0.147 & 0 & 126.2 & 27.31 \\
\hline
\end{tabular}

